MARTIN MARIETTA

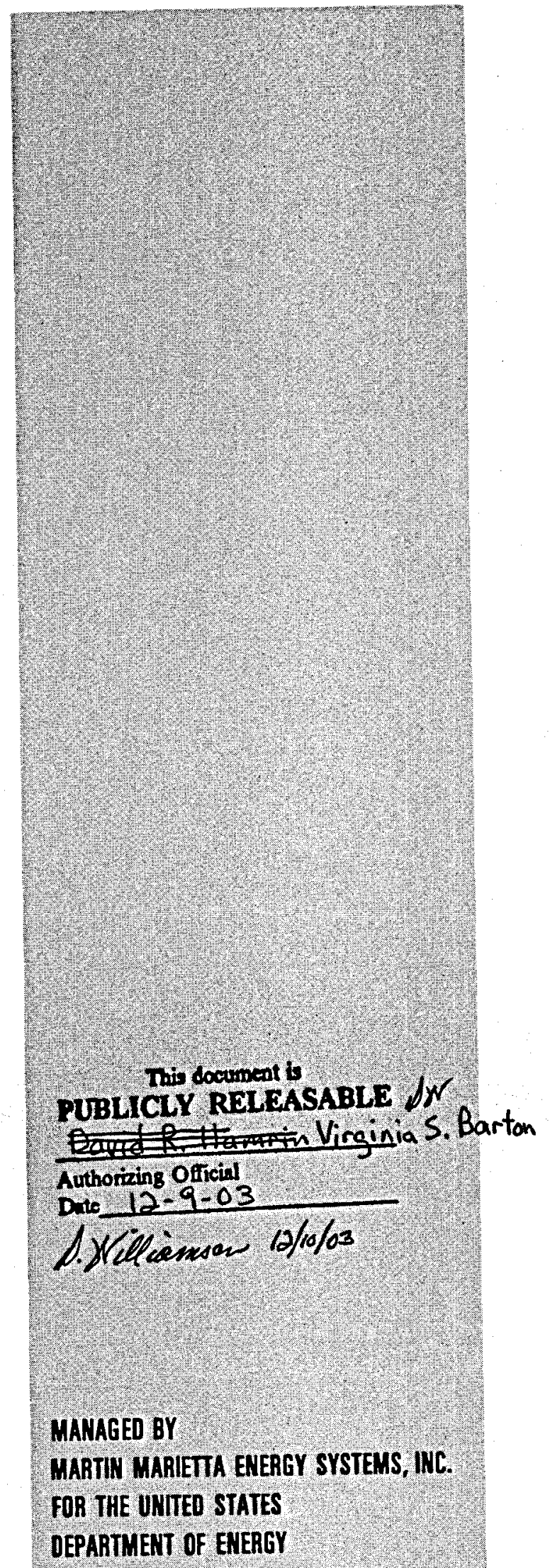

National Security Program Ofrice

\section{ENVIRONMENTAL MONITORING FOR DETECTION OF URANIUM ENRICHMENT OPERATIONS: COMPARISON OF LEU AND HEU FACILITIES}

D. M. Hembree, Jr.

J. A. Carter

H. H. Ross

March 1995 


\section{DISCLAIMER}

This report was prepared as an account of work sponsored by an agency of the United States Government. Neither the United States Government nor any agency thereof, nor any of their employees, makes any warranty, express or implied, or assumes any legal liability or responsibility for the accuracy, completeness, or usefulness of any information, apparatus, product, or process disclosed, or represents that its use would not infringe privately owned rights. Reference herein to any specific commercial product, process, or service by trade name, trademark, manufacturer, or otherwise, does not necessarily constitute or imply its endorsement, recommendation, or favoring by the United States Government or any agency thereof. The views and opinions of authors expressed herein do not necessarily state or reflect those of the United States Government or any agency thereof. 


\section{DISCLAIMER}

This report was prepared as an account of work sponsored by an agency of the United States Government. Neither the United States Government nor any agency thereof, nor any of their employees, makes any warranty, express or implied, or assumes any legal liability or responsibility for the accuracy, completeness, or usefulness of any information, apparatus, product, or process disclosed, or represents that its use would not infringe privately owned rights. Reference herein to any specific commercial product, process, or service by trade name, trademark, manufacturer, or otherwise does not necessarily constitute or imply its endorsement, recommendation, or favoring by the United States Government or any agency thereof. The views and opinions of authors expressed herein do not necessasily state or reflect those of the United States Government or any agency thereof. 


\section{DISCLAIMER}

Portions of this document may be illegible in electronic image products. Images are produced from the best available original document. 
National Sccurity Program Office

\section{ENVIRONMENTAL MONITORING FOR DETECTION OF URANIUM ENRICHMENT OPERATIONS: COMPARISON OF LEU AND HEU FACILITIES}

D. M. Hembree, Jr.

J. A. Carter

H. H. Ross

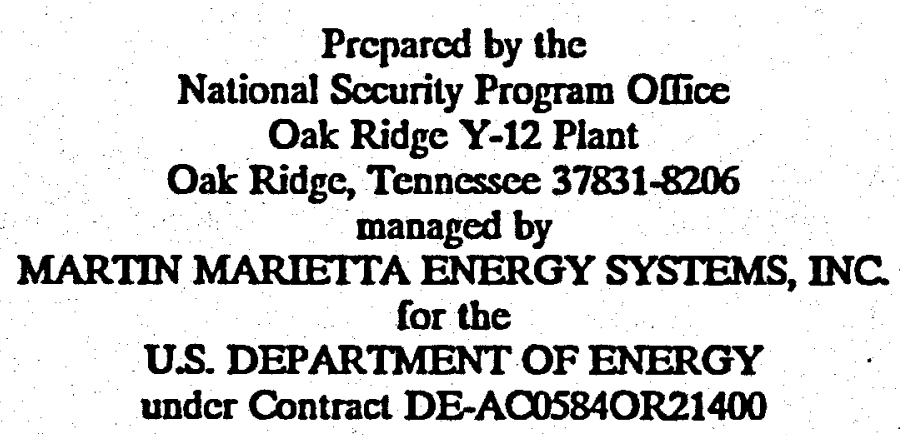


$b^{0}+4$

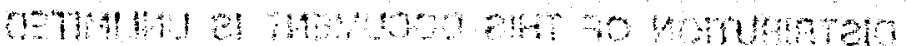


CONTENTS

LIST OF FIGURES $\ldots \ldots \ldots \ldots \ldots \ldots \ldots \ldots \ldots \ldots \ldots \ldots \ldots \ldots \ldots \ldots \ldots \ldots$

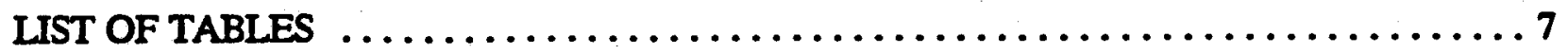

EXECUTTVE SUMMARY $\ldots \ldots \ldots \ldots \ldots \ldots \ldots \ldots \ldots \ldots \ldots \ldots \ldots$

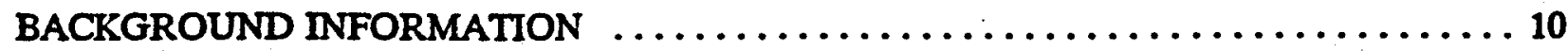

SAMPLING AND ANALYSIS $\ldots \ldots \ldots \ldots \ldots \ldots \ldots \ldots \ldots \ldots \ldots \ldots \ldots \ldots$

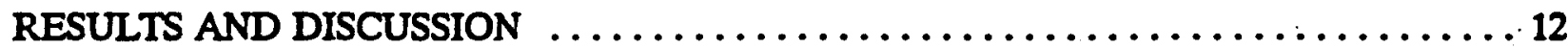

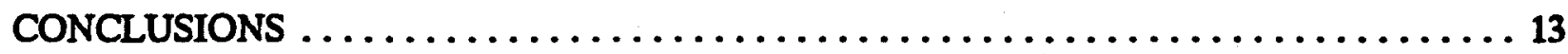

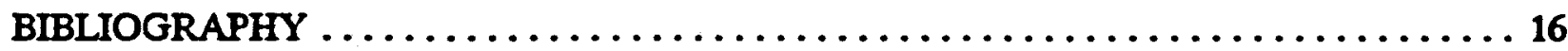

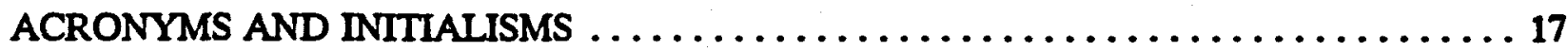

Appendix 1. DATA FROM BULK ANALYSIS OF ENVIRONMENTAL SAMPLES (SWIPES AND PINE NEEDLES) TAKEN DURING THE PADUCAH

AND PORTSMOUTH FIELD TRIALS $\ldots \ldots \ldots \ldots \ldots \ldots \ldots \ldots \ldots \ldots$

Appendix 2. DATA FROM PARTICULATE ANALYSIS OF ENVIRONMENTAL SAMPLES (SWTES AND PINE NEEDLES) TAKEN DURING THE PADUCAH AND PORTSMOUTH FIELD TRIALS $\ldots \ldots \ldots \ldots \ldots \ldots \ldots 25$

Appendix 3. COMPARISON OF BULK AND PARTICULATE DATA FROM SWIPE SAMPLES TAKEN DURING THE PORTSMOUTH FIELD TRIAL $\ldots \ldots \ldots 35$

Appendix 4. COMPARISON OF BULK AND PARTICULATE DATA FROM PINE NEEDLE SAMPLES TAKEN DURING THE PORTSMOUTH

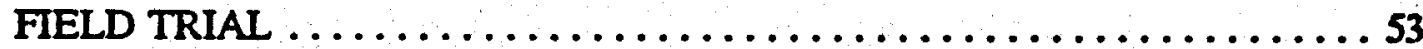

Appendix 5. COMPARISON OF BULK AND PARTICULATE DATA FROM SWIPE SAMPLES TAKEN DURING THE PADUCAH FIELD TRIAL 63

Appendix 6. COMPARISON OF BULK AND PARTICULATE DATA FROM PINE NEEDLE SAMPLES TAKEN DURING THE PADUCAH FIELD TRIAL . . 75

\section{DISCLAIMER}

This report was prepared as an account of work sponsored by an agency of the United States Government. Neither the United States Government nor any agency thereof, nor any of their employees, makes any warranty, express or implied, or assumes any legal liability or responsibility for the accuracy, completeness, or usefulness of any information, apparatus, product, or process disclosed, or represents that its use would not infringe privately owned rights. Reference herein to any specific commercial product, process, or service by trade name, trademark, manufacturer, or otherwise does not necessarily constitute or imply its endorsement, recommendation, or favoring by the United States Government or any agency thereof. The views and opinions of authors expressed herein do not necessarily state or reflect those of the United States Government or any agency thereof. 



\section{LIST OF FIGURES}

No.

$1 \quad$ Paducah Gaseous Diffusion Plant $\ldots \ldots \ldots \ldots \ldots \ldots \ldots \ldots \ldots \ldots \ldots$

$2 \quad$ Location of the Portsmouth site within the state of Ohio $\ldots \ldots \ldots \ldots \ldots$

3 Delayed neutron analysis of pine needles taken during the Paducah field trial . . . . 14

4 Delayed neutron analysis of pine needles taken during the Portsmouth field trial .. 14

5 Delayed neutron analysis of pine needles collected around Portsmouth when HEU was being produced $\ldots \ldots \ldots \ldots \ldots \ldots \ldots \ldots \ldots \ldots \ldots \ldots \ldots$

\section{LIST OF TABLES}

No.

1 Conclusions from results obtained by each environmental monitoring technique employed to analyze samples from the Paducah and Portsmouth field trials 



\section{EXECUTIVE SUMMARY}

In 1994, the International Atomic Energy Agency (LAEA) initiated an ambitious program of worldwide field trials to evaluate the utility of environmental monitoring for safeguards (Task 3 of Programme 93+2). Part of this program, conducted during the week of May 16-20, 1994, involved two extensive United States field trials conducted at the large uranium enrichment facilities at Paducah, Kentucky, and Portsmouth, Ohio. The Paducah operation involves a large low-enriched uranium (LEU) gaseous diffusion plant that has never exceeded $2.1 \%$ enrichment while the Portsmouth facilities include a large gaseous diffusion plant that has produced both LEU and highenriched uranium (HEU) (up to $97.5 \%{ }^{235} \mathrm{U}$ ) as well as an LEU centrifuge facility. As a result of the Energy Policy Act of 1992, management of the uranium enrichment operations at both of these sites was assumed by the U.S. Enrichment Corporation (USEC). The facilities are leased by USEC from the U.S. Department of Energy (DOE) and operated under contract by Martin Marietta Utility Services. Martin Marietta Energy Systems manages the environmental restoration and waste management programs at Portsmouth and Paducah for DOE.

These field trials were conducted by personnel from the Oak Ridge National Laboratory (ORNL) and the Savannah River Technology Center. IAEA inspectors were not involved in the trials. Samples included swipes from inside and outside process buildings, vegetation and soil samples taken from locations up to $\mathbf{8 k m}$ from main sites, and hydrologic samples taken on the sites and at varying distances from the sites. The hydrologic data will be covered in a separate report.

Most of the analytical results from bulk analysis were obtained using high abundance sensitivity thermal ionization mass spectrometers (TIMS) located at various laboratories in the DOE Network of Analytical Laboratories (NWAL).* Samples were prepared for analysis by TIMS using either leaching or total dissolution methods, depending on the analytical methodology in place at a given DOE laboratory. Some of the vegetation samples (pine needles) were subjected to delayed neutron analysis at the High Flux Isotope Reactor located at ORNL. Delayed neutron analysis provides a measure of the level of certain fissile isotopes in a given sample, and is particularly sensitive to ${ }^{23} \mathrm{U}$. A complete set of swipes with controls and pine needle samples was also sent to the Air Force Technical Applications Center (AFTAC) for particulate analysis.

Uranium isotopies altered from the normal background percentages were found for all the sample types listed above, even on vegetation $5 \mathrm{~km}$ from one of the enrichment facilities. The results from these field trials demonstrate that dilution by natural background uranium does not remove from environmental samples the distinctive signatures that are characteristic of enrichment operations. Data from swipe samples taken within the enrichment facilities were particularly revealing. In the Portsmouth Gaseous Diffusion Plant, which has produced $97.5 \%{ }^{235} \mathrm{U}$ with tails less than $0.4 \%$, bulk analysis of a swipe near the top end of the cascade (but not at the final product area) gave a ${ }^{235} U$ value of $88.88 \%$, while two swipes from the tails area gave $0.3006 \%$ and $0.2966 \%{ }^{255}$ U. Particulate analysis of these swipes provided a detailed "history" of both facilities, including the assays of the end product and tails for both facilities. These field trials demonstrate conclusively that directed sampling with swipes within nuclear facilities gives clear evidence of the nature of the processes occurring there.

- The DOE NWAL is composed of Savannah River Technology Center, Oak Ridge National Laboratory, Los Alamos National Laboratory, Lawrence Livermore National Laboratory, Pacific Northwest Laboratories, and New Brunswick Laboratory. 


\section{BACKGROUND INFORMATION}

The Paducah Gaseous Diffusion Plant is located in western Kentucky on the Ohio River near the border of Illinois (Fig. 1). The Ohio and Tennessee Rivers join approximately $24 \mathrm{~km}$ upstream from Paducah, while the Ohio River empties into the Mississippi River approximately $90 \mathrm{~km}$ below the site. The wind rose for the Paducah site shows the primary wind direction and speed is from the south/southwest at $2-4 \mathrm{~m} / \mathrm{s}$; however, the wind blows in most other directions with similar frequency. The plant started operations in 1952 supplying LEU for commercial reactors and military defense reactors and has enriched uranium no higher than $2.1 \%$.

The Portsmouth facility is located approximately $43 \mathrm{~km}$ north of the city of Portsmouth on a $16.2 \mathrm{~km}^{2}$ site in a sparsely populated part of southern Ohio (Fig. 2). The site is located approximately $1.6 \mathrm{~km}$ east of the Scioto River which joins the Ohio River $-45 \mathrm{~km}$ to the south. Wind rose information indicates that the wind blows predominantly from the south or south/southwest at 0-2 m/s. The Portsmouth facilities produced HEU until 1992 when HEU operations ceased. The plant continues to produce LEU by gaseous diffusion. The centrifuge facility at Portsmouth started operation in July 1983 and had a top enrichment of 3.2\%. The plant was shutdown in July 1985.

Both the Portsmouth and Paducah sites have extensive environmental monitoring programs mandated by state and federal agencies. Detailed environmental reports covering external gamma radiation, ambient air, surface water, sediment, soil, vegetation, food crops, fish, wildlife, and groundwater are available for both facilities (ES/ESH-36, KY/E-164 and ES/ESH-50, POEF-3050).

\section{SAMPLING AND ANALYSIS}

To avoid any possibility of introducing HEU contamination from Portsmouth, the field trial began with the LEU facilities at Paducah. Contamination control was crucial because a set of samples from both facilities was sent to AFTAC for particulate analysis.

Swipe samples were collected using the same sampling procedure taught to IAEA inspectors at the March 1994, workshop in Oak Ridge, Tennessee. Briefly, swipe kits were prepared in advance (by AFTAC), and the collector/assistant procedure was used to ensure that no cross-contamination occurred. All sampling was performed from clean work areas (aluminum foil) and the samples were carefully double-bagged. Swipe sampling points were chosen to increase the likelihood that the sample would reflect the actual enrichment at given points in the process. Directed sampling at locations such as sampling stations, chemical traps, vents, product removal or transfer areas, and analytical laboratory equipment used to determine assay are all excellent areas to take swipe samples. Swipe samples were taken near the product and tails process areas as well as intermediate points along the cascades for both the Paducah and Portsmouth gaseous diffusion plants. In addition, swipe samples were taken in the analytical laboratory of the LEU centrifuge facility at Portsmouth (now shutdown). Samples could not be taken directly in the HEU product removal area of the Portsmouth plant because of safety concerns regarding high radiation levels in this area.

Vegetation samples were taken at $0,1,3$, and $5 \mathrm{~km}$ from the Portsmouth site and at the same distances from the Paducah site, plus one more set of samples at $8 \mathrm{~km}$. Although a range of samples were taken at each sampling point (e.g., pine needles, bark, grass, deciduous leaves, moss, lichen, and soil) only the high-priority pine needle samples were analyzed by TIMS, delayed neutron, and particulate analysis in this study. Sampling directions from each site were chosen along the predominant wind directions where possible.

At the conclusion of the field trial, all samples were transported directly to the ORNL off-site sample receiving and processing facility. The samples were distributed to the DOE NWAI and AFTAC in late May and early June 1994. Reporting of data from these samples was delayed because of the requirement for a review of the report by both facilities. 


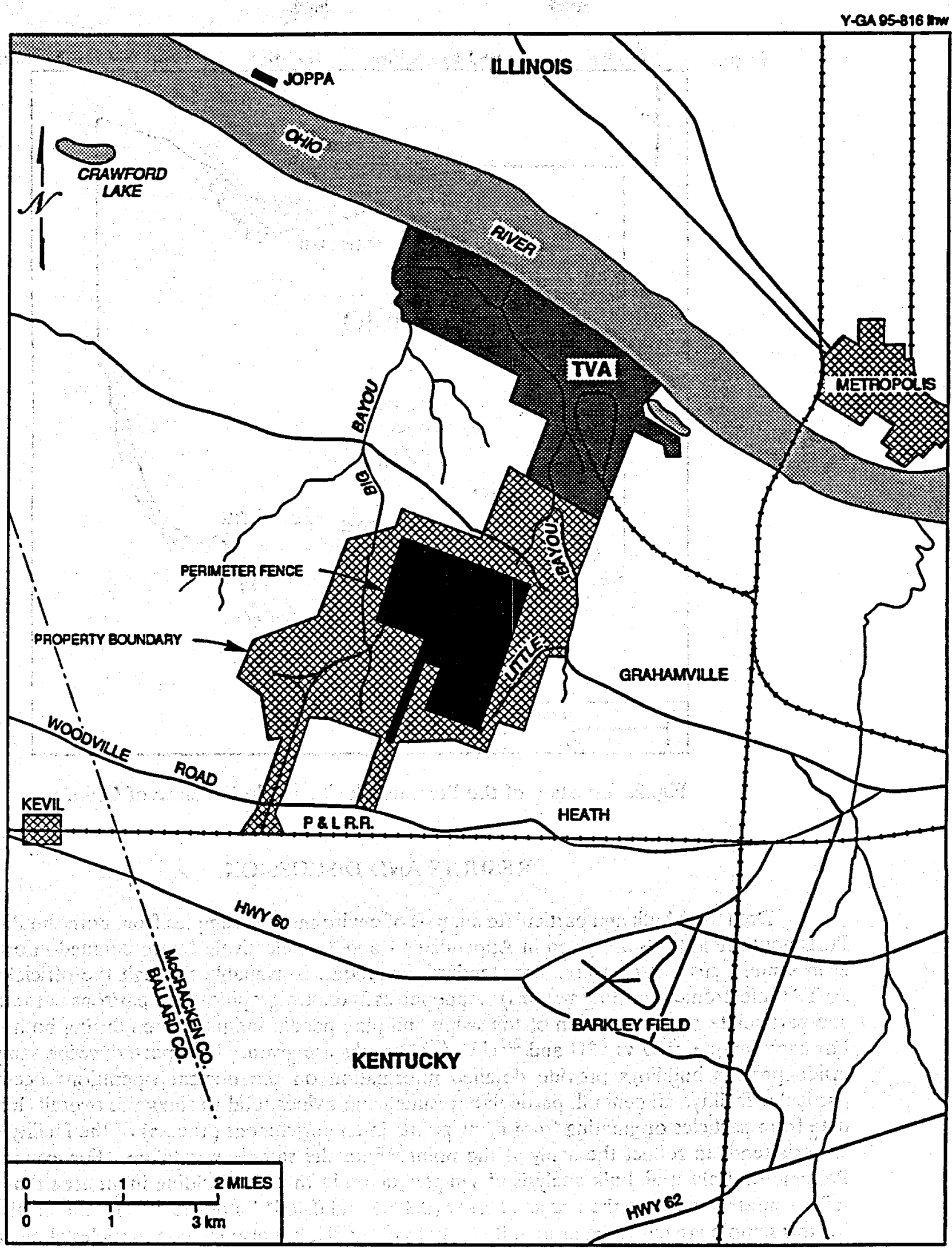

Fig. 1. Paducah Gaseous Diffusion Plant. 


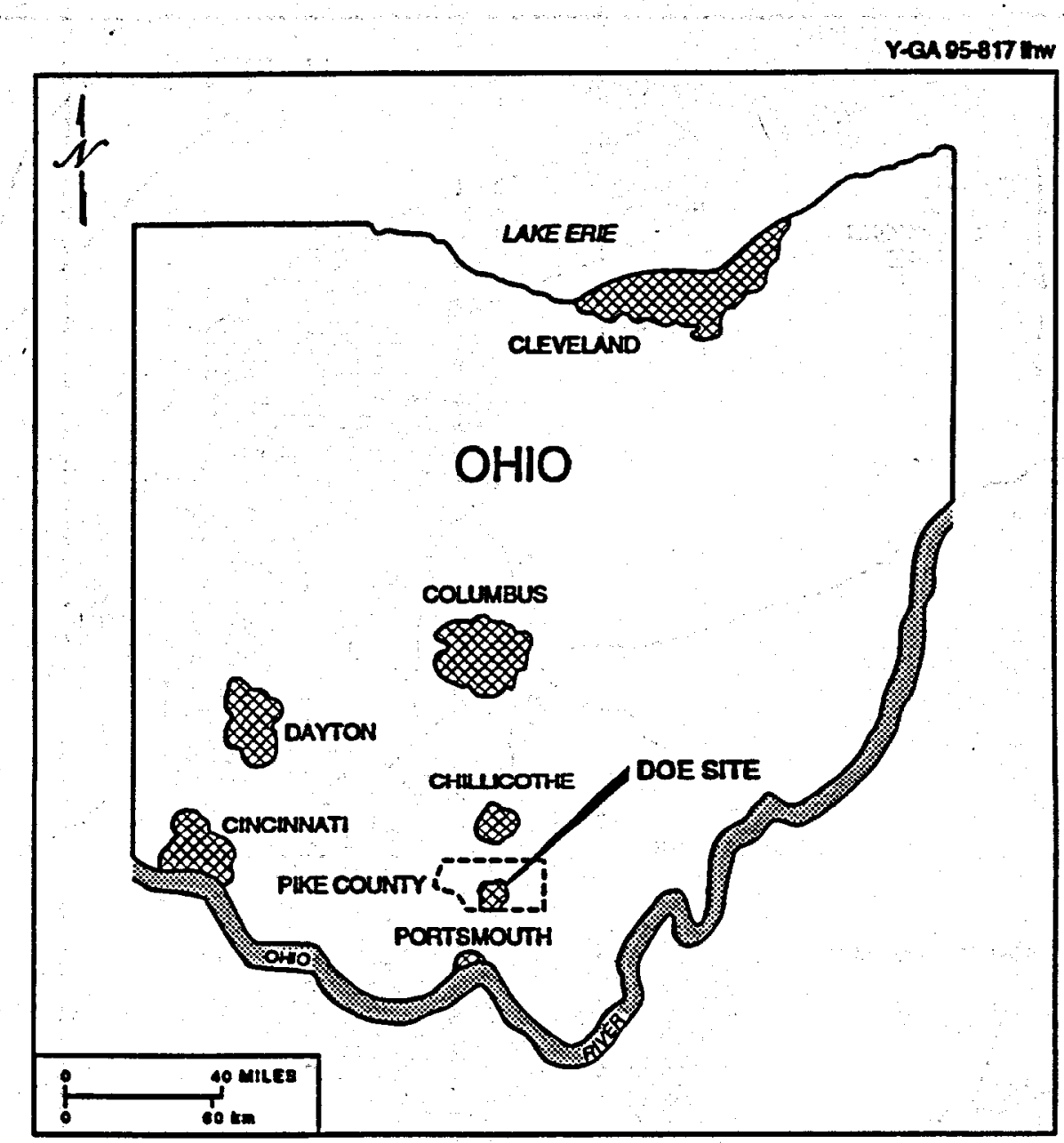

Fig. 2. Location of the Portsmouth site within the state of Ohio.

\section{RESULTS AND DISCUSSION}

Data from bulk and particulate analysis of environmental samples from both the Paducah and Portsmouth field trials are given in Appendixes 1 and 2, respectively (more detailed information for each sample, such as measurement standard deviations, is available through the official DOE and AFTAC electronic reporting systems). Appendixes 3-6 show graphical comparisons between the bulk and particulate results for each of the swipe and pine needle samples taken during both field trials. For each sample, ${ }^{235} \mathrm{U}$ vs ${ }^{234} \mathrm{U}$ and ${ }^{235} \mathrm{U}$ vs ${ }^{236} \mathrm{U}$ graphs are given. As expected, swipe samples taken inside process buildings provide detailed information on the nuclear operations occurring at a particular facility. In general, particulate results from swipes tend to show the overall "history" (i.e., data from particles originating from many points in an enrichment process) of the facility while bulk analysis tends to reflect the assay at the point where the sample was taken. For example, in the Portsmouth field trial, bulk analysis of samples taken in the 330 Building in an area that processed tails accurately measure the expected assay $\left(0.3006\right.$ and 0.40514 atom $\left.\%{ }^{235} \mathrm{U}\right)$. The particulate data for this sample are clustered around $0.3-0.4$ atom $\%{ }^{235} \mathrm{U}$, but also include particles above and below the expected assay. Examination of the swipe data in Appendixes 1, 2, 3, and 5 provide many more 
examples of particulate data showing detailed "history" and bulk data measuring the assay at the sampling point. For both facilities, the assays of both the product and tails were established precisely by the particulate data. Surprisingly, bulk analysis also provided reasonable values from swipe samples taken in the product and tails areas. It was thought before this field trial that dilution effects from natural uranium and from uranium originating from other points in the cascade would dramatically skew the results of bulk analysis.

The results from analysis of vegetation samples (pine needles) by bulk and particulate analysis are given as raw data in Appendixes 1 and 2 and compared in graphical form in Appendixes 4 and 6. Particulate data from these samples provide very little information for either facility, except for the sample taken on-site at Portsmouth. Particulate data from pine needles collected off-site for both facilities is clustered around natural uranium $\left(0.72\right.$ atom $\left.\%{ }^{235} \mathrm{U}\right)$. However, altered uranium isotopies can clearly be detected out to $5 \mathrm{~km}$ in the bulk data for the Portsmouth pine needles. Data from bulk analysis of the pine needles collected around the LEU facility at Paducah are similar to the particulate results-clustered around natural for most samples. The uranium concentrations reported in Appendix 1 for the pine needle samples are consistent with previously reported data in the annual environmental reports for each site.

Delayed neutron analysis was performed on pine needle samples taken at varying distances from both sites in these field trials. The purpose of using delayed neutron analysis was to investigate its utility as a screening tool to identify high-value samples that could then be subjected to more expensive detailed analysis. The concentrations reported were computed assuming that any uranium detected had natural background isotopic values (a high delayed neutron reading indicates the sample contains either a large quantity of natural uranium or contains a small quantity of uranium that has a large fraction of fissile ${ }^{235} \mathrm{U}$ ). Figure 3 shows the results obtained around the LEU facility at Paducah, Kentucky. In most cases, the uranium concentration is well below $50 \mathrm{ppb}$ and is in the range expected for normal background uranium on pine needles. (National Institute of Standards and Technology (NIST) standard reference material 1575, pine needles, was taken from pine trees in upper Michigan well away from nuclear operations, and contains $20 \pm 4 \mathrm{ppb}$ of natural uranium.] Figure 4 shows the results for pine needles collected around the Portsmouth facility. Even though HEU operations ceased 2 years prior to this field trial, the delayed neutron data shows clear evidence of altered uranium isotopics near the plant. The uranium concentration drops continuously with distance from the plant out to $5 \mathrm{~km}$, where levels near background were found. Figure 5 is a simulation of delayed neutron results where the concentrations were computed from TIMS data taken from a study conducted when HEU was being produced. As can be seen in Fig. 5 , the simulated delayed neutron signature (i.e., deviation from normal background concentration) is much more distinctive and can be detected at greater distances.

\section{CONCLUSIONS}

The results of these field trials (see Table 1) demonstrate, as expected, that particulate analysis of swipes obtained from inside nuclear facilities provides unmistakable signatures of the facility's past and present operations. This study also demonstrates that bulk analysis of swipe samples obtained by directed sampling (i.e., sampling in specific locations that are more likely to be exposed to process material) inside nuclear facilities provides very good estimates of the assay at that particular sampling location. In general, it was found that characteristic signatures of both LEU and HEU operations are easily detected from swipe samples analyzed by bulk analytical methods. 


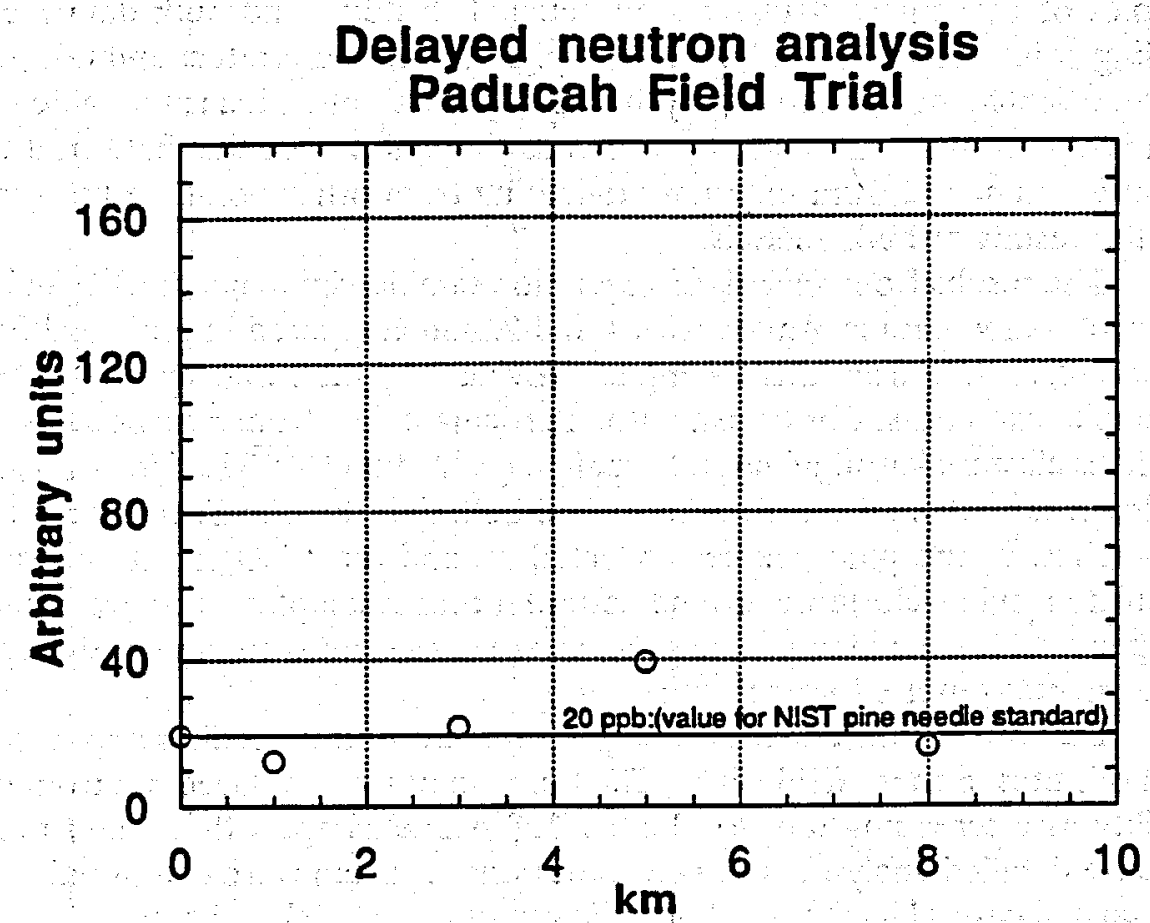

Fig. 3. Delayed neutron analysis of pine needles taken during the Paducah field trial The y-scale is given in arbitrary units, but would be $\mathrm{ppb}$ if all the uranium in the sample had natural isotopic composition.

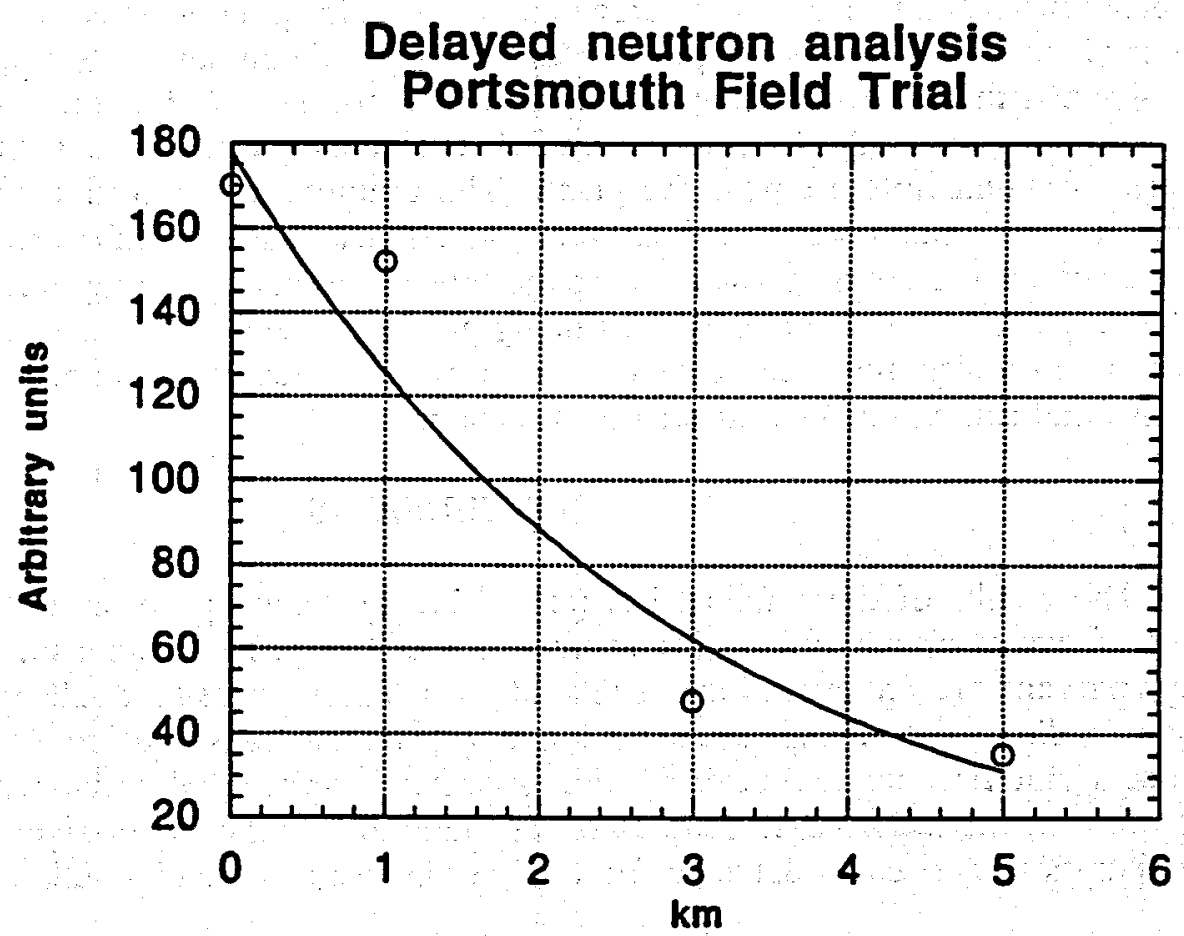

Fig. 4. Delayed neutron analysis of pine needles taken during the Portsmouth field trial The y-scale is given in arbitrary units, but would be ppb if all the uranium in the sample had natural isotopic composition. 


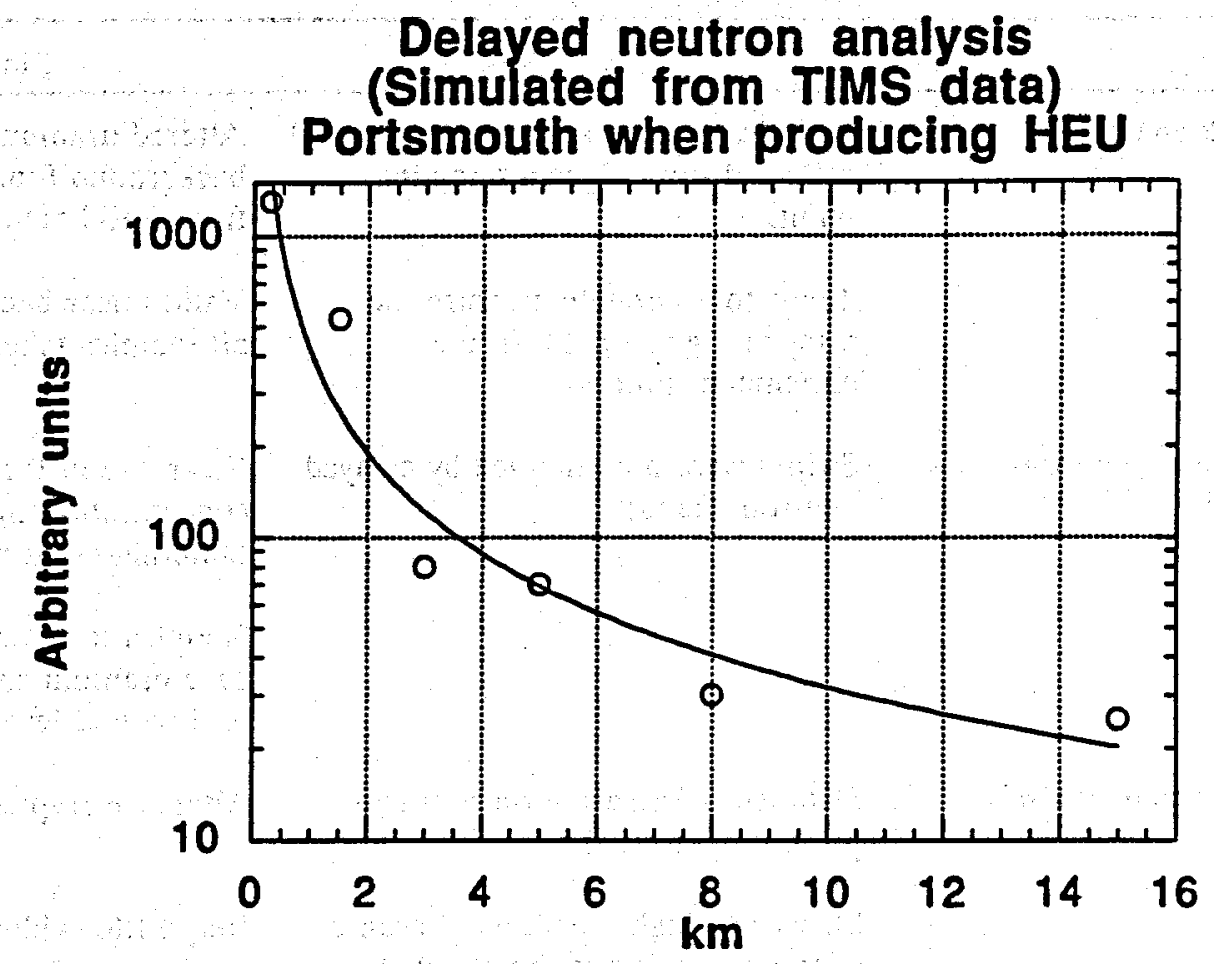

Fig. 5. Delayed neutron analysis of pine needles collected around Portsmouth when HEU was being produced. The y-scale is given in arbitrary units, but would be ppb if all the uranium in the sample had natural isotopic composition.

Bulk and particulate analysis of pine needle samples around the operating LEU facility at Paducah produced very little data indicating that nuclear operations existed in the facilities. The delayed neutron data also showed very little deviation from the normal uranium background. Conversely, even though HEU production ceased 2 years before the Portsmouth field trial, clear indications of altered isotopics out to $5 \mathrm{~km}$ were found in both the bulk analytical and delayed neutron data from pine needles. In this study, a rapid increase in the delayed neutron signal near the site coupled with evidence of altered isotopics from vegetation collected away from the facility provided strong evidence of HEU operations. Unexpectedly, the particulate data for the Portsmouth pine needles showed very little evidence of nuclear operations, except for the sample taken on-site. 
Table 1. Conclusions from results obtained by each environmental monitoring technique employed to analyze samples from the

Paducah and Portsmouth field trials

\begin{tabular}{|c|c|c|}
\hline & Swipes & Pine needles \\
\hline Bulk analysis & $\begin{array}{l}\text { Provides average assay of all material } \\
\text { collected from a given sampling } \\
\text { point. } \\
\text { Tends to accurately measure the } \\
\text { assay at a given point in the } \\
\text { enrichment process. }\end{array}$ & $\begin{array}{l}\text { Altered uranium isotopics well above } \\
\text { background found up to } 5 \mathrm{~km} \text { away } \\
\text { from HEU facility. } \\
\text { Values near background found for } \\
\text { all samples taken at LEU site. }\end{array}$ \\
\hline $\begin{array}{l}\text { Delayed neutron } \\
\text { analysis }\end{array}$ & $\begin{array}{l}\text { Swipes were not analyzed by delayed } \\
\text { neutron analysis. }\end{array}$ & $\begin{array}{l}\text { Clear rise in the apparent uranium } \\
\text { concentration the closer the } \\
\text { sampling point was to HEU facility. } \\
\text { Samples from around LEU facility } \\
\text { gave uranium concentrations near } \\
\text { background levels. }\end{array}$ \\
\hline \multirow[t]{2}{*}{ Particulate analysis } & $\begin{array}{l}\text { Detailed information on past and } \\
\text { present operations. }\end{array}$ & Altered isotopies detected on-site. \\
\hline & $\begin{array}{l}\text { Skewed to higher isotopics because } \\
\text { of the way particles are selected. }\end{array}$ & $\begin{array}{l}\text { Very little evidence of HEU or LEU } \\
\text { production detected off-site. }\end{array}$ \\
\hline
\end{tabular}

\section{BIBLIOGRAPHY}

1. Paducah Gaseous Diffusion Plant Environmental Report for 1992, ES/ESH-36, KY/E-164, Martin Marietta Energy Systems, Inc., September 1993.

2. Portsmouth Gaseous Diffusion Plant Annual Site Environmental Report for 1993, ES/ESH-50, POEF-3050, Martin Marietta Energy Systems, Inc., November 1994. 


\section{ACRONYMS AND INITIALISMS}

AFTAC

DOE

HEU

IAEA

LEU

NIST

NWAL

ORNL

TIMS

USEC
Air Force Technical Applications Center

Department of Energy

high-enriched uranium

International Atomic Energy Agency

low-enriched uranium

National Institute of Standards and Technology

Network of Analytical Laboratories

Oak Ridge National Laboratory

thermal ionization mass spectrometer

U.S. Enrichment Corporation 

Appendix 1

DATA FROM BULK ANALYSIS OF ENVIRONMENTAI SAMPLES (SWIPES AND PINE NEEDLES) TAKEN DURING THE

PADUCAH AND PORTSMOUTH FIELD TRIALS 



\begin{tabular}{|c|c|c|c|c|}
\hline $\begin{array}{l}\text { Eacility } \\
\text { (enrichment) }\end{array}$ & U-234 & $\frac{\text { Atom\% }}{\mathrm{U}-235}$ & U-236 & U6238 \\
\hline $\begin{array}{c}330 \text { Building } \\
(<0.4 \%)\end{array}$ & $\begin{array}{l}0.001313 \\
0.002330\end{array}$ & $\begin{array}{c}0.3006 \\
0.40514\end{array}$ & $\begin{array}{c}0.000496 \\
0\end{array}$ & $\begin{array}{r}99.6976 \\
99.59253\end{array}$ \\
\hline $\begin{array}{l}330 \text { Building } \\
(2.5 \%)\end{array}$ & $\begin{array}{l}0.0269 \\
0.0133\end{array}$ & $\begin{array}{l}2.938 \\
1.814\end{array}$ & $\begin{array}{l}0.00205 \\
0.0010\end{array}$ & $\begin{array}{l}97.033 \\
98.171\end{array}$ \\
\hline $\begin{array}{l}344 \text { Building } \\
(<5 \%)\end{array}$ & $\begin{array}{c}0.01321 \\
0.0139\end{array}$ & $\begin{array}{l}1.8076 \\
1.803\end{array}$ & $\begin{array}{l}0.00352 \\
0.00397\end{array}$ & $\begin{array}{l}98.176 \\
98.179\end{array}$ \\
\hline $\begin{array}{l}330 \text { Building } \\
(5 \%)\end{array}$ & $\begin{array}{l}0.03273 \\
0.03266 \\
0.02637\end{array}$ & $\begin{array}{c}3.419 \\
3.385 \\
3.0308\end{array}$ & $\begin{array}{c}0.002280 \\
0.00218 \\
0\end{array}$ & $\begin{array}{c}96.546 \\
96.580 \\
96.9428\end{array}$ \\
\hline $\begin{array}{l}326 \text { Building } \\
\text { (25\%) }\end{array}$ & $\begin{array}{l}0.3862 \\
1.8204\end{array}$ & $\begin{array}{c}26.76 \\
88.8869\end{array}$ & $\begin{array}{l}0.02224 \\
0.0143\end{array}$ & $\begin{array}{l}72.83 \\
9.2784\end{array}$ \\
\hline $\begin{array}{l}326 \text { Building } \\
\text { (97\%) }\end{array}$ & 0.5170 & 34.949 & 0.02652 & 64.508 \\
\hline $\begin{array}{l}326 \text { Building } \\
\text { (97\%) }\end{array}$ & $\begin{array}{c}0.33258 \\
0.272\end{array}$ & $\begin{array}{l}26.199 \\
20.198\end{array}$ & $\begin{array}{c}0.02547 \\
0.020\end{array}$ & $\begin{array}{c}73.44 \\
79.501\end{array}$ \\
\hline $\begin{array}{c}\text { PB1 (3001) } \\
\text { Centrifuge } \\
(3-4 \%)\end{array}$ & $\begin{array}{l}0.0084 \\
0.0103\end{array}$ & $\begin{array}{l}1.176 \\
1.120\end{array}$ & $\begin{array}{l}0.0058 \\
0.0015\end{array}$ & $\begin{array}{l}98.810 \\
98.789\end{array}$ \\
\hline
\end{tabular}




\section{PINE NEEDLE SAMPLES BULK ANALYSIS PORTSMOUTH FIELD TRIAL}

\begin{tabular}{|c|c|c|c|c|}
\hline$\frac{\text { Distance } \mathbf{k m}}{\text { (ng/g) }}$ & U-234 & $\frac{\text { Atom\% }}{\mathbf{U}-235}$ & $\mathrm{U}=236$ & U-238 \\
\hline $\begin{array}{c}0 \mathrm{~km} \\
(39.4823)\end{array}$ & $\begin{array}{c}0.1083 \\
0.041\end{array}$ & $\begin{array}{c}10.0054 \\
1.79\end{array}$ & $\begin{array}{c}0 \\
0.0282\end{array}$ & $\begin{array}{l}89.8863 \\
98.143\end{array}$ \\
\hline${ }_{(22.167,0.147)}^{1 ~ k m}$ & $\begin{array}{l}0.03011 \\
0.014\end{array}$ & $\begin{array}{l}3.1011 \\
1.446\end{array}$ & $\begin{array}{c}0.003048 \\
0.0072\end{array}$ & $\begin{array}{l}96.8658 \\
98.533\end{array}$ \\
\hline $\begin{array}{c}3 \mathrm{~km} \\
(17.7653)\end{array}$ & $\begin{array}{l}0.00972 \\
0.01291\end{array}$ & $\begin{array}{l}1.01999 \\
1.4454\end{array}$ & $\begin{array}{c}0 \\
0.00134\end{array}$ & $\begin{array}{c}98.97029 \\
98.540\end{array}$ \\
\hline $\begin{array}{c}5 \mathrm{~km} \\
(15.547,0.147)\end{array}$ & $\begin{array}{c}0.01386 \\
0.025\end{array}$ & $\begin{array}{l}1.6290 \\
1.920\end{array}$ & $\begin{array}{c}0.00229 \\
0.009\end{array}$ & $\begin{array}{l}98.3549 \\
98.046\end{array}$ \\
\hline
\end{tabular}




\section{SWIPE SAMPLES \\ BULK ANALYSIS \\ PADUCAH FIELD TRIAL}

\begin{tabular}{|c|c|c|c|c|}
\hline $\begin{array}{c}\text { Eacility } \\
\text { (enrichment) }\end{array}$ & IJ-234 & $\frac{\text { Atom\% }}{\mathbf{U}-235}$ & U-236. & U-238. \\
\hline $\begin{array}{l}\text { C315 Building } \\
\text { (0.3\%) }\end{array}$ & $\begin{array}{l}0.001579 \\
0.00179 \\
0.00182\end{array}$ & $\begin{array}{l}0.3117 \\
0.34619 \\
0.3400\end{array}$ & $\begin{array}{c}0.00248 \\
0.00045 \\
0\end{array}$ & $\begin{array}{l}99.6843 \\
99.6516 \\
99.6580\end{array}$ \\
\hline $\begin{array}{l}\text { C333A } \\
\text { Building } \\
(0.72 \%)\end{array}$ & $\begin{array}{l}0.00229 \\
0.0047 \\
0.0045\end{array}$ & $\begin{array}{l}0.63503 \\
0.683 \\
0.6831\end{array}$ & $\begin{array}{l}0 \\
0 \\
0\end{array}$ & $\begin{array}{l}99.3627 \\
99.31 \\
99.31\end{array}$ \\
\hline $\begin{array}{c}\text { C331 Building } \\
\text { (1\%) }\end{array}$ & $\begin{array}{l}0.00700 \\
0.00391 \\
0.0066\end{array}$ & $\begin{array}{l}0.9377 \\
0.63431 \\
0.899\end{array}$ & $\begin{array}{l}0.00086 \\
0.00262 \\
0.00204\end{array}$ & $\begin{array}{l}99.0545 \\
99.3592 \\
99.092\end{array}$ \\
\hline $\begin{array}{c}\text { C310 Building } \\
(1.8-2.1 \%)\end{array}$ & $\begin{array}{l}0.00593 \\
0.00843\end{array}$ & $\begin{array}{l}0.8102 \\
1.0085\end{array}$ & $\begin{array}{c}0.000707 \\
0\end{array}$ & $\begin{array}{l}99.1831 \\
98.9830\end{array}$ \\
\hline $\begin{array}{l}\text { Railroad sign } \\
\text { near C310 }\end{array}$ & 0.00405 & 0.6207 & 0.00246 & 99.3728 \\
\hline
\end{tabular}


PINE NEEDLE SAMPLES BULK ANALYSIS

PADUCAH FIELD TRIAL

\begin{tabular}{|c|c|c|c|c|}
\hline$\frac{\text { Distance. km }}{\text { (ng/g) }}$ & U-234 & $\frac{\text { Atom\% }}{\mathbf{U}-235}$ & U-236 & U-238 \\
\hline $\begin{array}{c}0 \mathrm{~km} \\
(13.742,0.177)\end{array}$ & $\begin{array}{l}0.00591 \\
0.0013\end{array}$ & $\begin{array}{c}0.7325 \\
0.579\end{array}$ & $\begin{array}{l}0.00160 \\
0.0066\end{array}$ & $\begin{array}{l}99.2600 \\
99.413\end{array}$ \\
\hline$\underset{(53.6166)}{1 ~ k m}$ & $\begin{array}{l}0.00606 \\
0.00536\end{array}$ & $\begin{array}{l}0.72171 \\
0.7139\end{array}$ & 0.00028 & $\begin{array}{l}99.2722 \\
99.280\end{array}$ \\
\hline $\begin{array}{c}3 \mathrm{~km} \\
(15.946,0.850)\end{array}$ & $\begin{array}{l}0.005529 \\
0.0061\end{array}$ & $\begin{array}{c}0.73032 \\
0.736\end{array}$ & $\begin{array}{c}0.000301 \\
0.017\end{array}$ & $\begin{array}{c}99.26384 \\
99.241\end{array}$ \\
\hline $\begin{array}{c}5 \mathrm{~km} \\
(20.3767)\end{array}$ & $\begin{array}{c}0.00640 \\
0.0059 \\
0.00540\end{array}$ & $\begin{array}{c}0.79616 \\
0.721 \\
0.7207\end{array}$ & $\begin{array}{c}0 \\
0 \\
0.00008\end{array}$ & $\begin{array}{l}99.1974 \\
99.27 \\
99.274\end{array}$ \\
\hline $\begin{array}{c}8 \mathrm{~km} \\
(30.396,0.545)\end{array}$ & $\begin{array}{l}0.00538 \\
0.0054\end{array}$ & $\begin{array}{c}0.7246 \\
0.718\end{array}$ & $\begin{array}{c}0 \\
0.0017\end{array}$ & $\begin{array}{l}99.2701 \\
99.275\end{array}$ \\
\hline
\end{tabular}


Appendix 2

DATA FROM PARTICULATE ANALYSIS OF ENVIRONMENTAL SAMPLES (SWIPES AND PINE NEEDLES) TAKEN DURING THE PADUCAH AND PORTSMOUTH FIELD TRIALS 
AFTAC Portsmouth swipes

\begin{tabular}{|c|c|c|c|}
\hline & Atom\% U-234 & Arom\% 4 -235 & Atom\% L-236 \\
\hline 0 & & & \\
\hline 1 & 5010-01-02 & Portsmouth & $344(5 \%)$ \\
\hline 2 & 0.032900 & 8.9584 & \\
\hline 3 & 0.020300 & 2.3136 & 0.0018000 \\
\hline 4 & 0.0094000 & 1.1489 & 0.0017000 \\
\hline 5 & 0.036900 & 3.8941 & 0.0022000 \\
\hline 6 & 0.036600 & 4.0406 & 0.00040000 \\
\hline 7 & 0.037100 & 3.9925 & 0.0020000 \\
\hline 8 & 0.034600 & 3.8369 & \\
\hline 8 & 0.035800 & 3.8567 & 0.0025000 \\
\hline 10 & 0.029800 & 3.1917 & 0.0045000 \\
\hline 11 & 0.038800 & 4.1827 & 0.0023000 \\
\hline 12 & 0.040400 & 4.2767 & 0.0022000 \\
\hline 13 & 0.034500 & 3.7601 & 0.00030000 \\
\hline 14 & 0.030500 & 3.2888 & 0.010500 \\
\hline 15 & 0.036300 & 3.8910 & 0.0013000 \\
\hline 16 & 0.0077000 & 0.85830 & 0.00020000 \\
\hline 17 & & 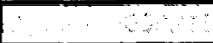 & \\
\hline 18 & $5010-02-02$ & Portsmouth & $330(5 \%)$ \\
\hline 19 & 0.069500 & 11.270 & 0.054300 \\
\hline 20 & 0.0040000 & 0.66230 & 0.00030000 \\
\hline 21 & 0.045800 & 6.0215 & 0.0071000 \\
\hline 22 & 0.044900 & 7.5893 & 0.035500 \\
\hline 23 & 0.12080 & 7.1155 & 0.0011000 \\
\hline 24 & 0.12710 & 8.6528 & 0.0013000 \\
\hline 25 & 0.84660 & 64.747 & 0.089400 \\
\hline 26 & 0.017300 & 2.2717 & 0.011500 \\
\hline 27 & 1.7584 & 93.269 & 0.014600 \\
\hline 28 & 0.053400 & 5.5656 & 0.0080000 \\
\hline 29 & 0.047500 & 5.1607 & 0.0025000 \\
\hline 30 & 0.026200 & 3.0299 & 0.00080000 \\
\hline 31 & 0.049100 & 4.8629 & 0.00070000 \\
\hline 32 & 0.076400 & 5.7046 & 0.0011000 \\
\hline 33 & 0.18840 & 10.879 & 0.00070000 \\
\hline 34 & \begin{tabular}{|l|l|l} 
& 6
\end{tabular} & & 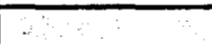 \\
\hline 35 & S010-03-02 & Portsmouth & $330(2.5 \%)$ \\
\hline 36 & 0.015100 & 1.9634 & 0.00020000 \\
\hline 37 & 0.013200 & 1.8336 & $1.00000-04$ \\
\hline 38 & 0.0027000 & 0.52180 & 0.0000 \\
\hline 39 & 0.016300 & 2.1748 & 0.0000 \\
\hline 40 & 0.0065000 & 1.4508 & 0.013100 \\
\hline 41 & 0.0095000 & 1.4758 & 0.0015000 \\
\hline 42 & 0.0074000 & 1.2183 & 0.0039000 \\
\hline 43 & 0.013200 & 1.8117 & $1.00000-04$ \\
\hline 44 & 0.016900 & 2.8765 & 0.014300 \\
\hline 45 & 0.013000 & 1.7028 & $1.00000-04$ \\
\hline 46 & 0.0082000 & 1.4952 & 0.0091000 \\
\hline
\end{tabular}


AFTAC Portsmouth swipes (cont)

\begin{tabular}{|l|l|l|l|}
\hline & Atom\%U-234 & \multicolumn{1}{|c|}{ Atom\%U-235 } & \multicolumn{1}{|c|}{ Atom\% U-236 } \\
\hline 47 & 0.0011000 & 0.30610 & 0.0027000 \\
\hline 48 & 0.011200 & 1.7080 & 0.0039000 \\
\hline 49 & 0.012100 & 1.7914 & 0.0039000 \\
\hline 50 & 0.0027000 & 0.51660 & 0.0000 \\
\hline 51 & & & \\
\hline 52 & $5010-04-03$ & Pontmouth & $330(0.4 \%)$ \\
\hline 53 & 0.0025000 & 0.45410 & 0.0031000 \\
\hline 54 & 0.00070000 & 0.21900 & $1.00000-04$ \\
\hline 55 & 0.00070000 & 0.21740 & 0.0000 \\
\hline 56 & 0.0014000 & 0.36330 & 0.0000 \\
\hline 57 & 0.040000 & 4.1011 & 0.00020000 \\
\hline 58 & & 1.7145 & \\
\hline 59 & 0.0012000 & 0.27710 & 0.00090000 \\
\hline 60 & 0.00080000 & 0.22720 & 0.00020000 \\
\hline 61 & 0.0021000 & 0.40160 & 0.0024000 \\
\hline 62 & 0.00070000 & 0.21550 & 0.0000 \\
\hline 63 & 0.0016000 & 0.36890 & $1.00000-04$ \\
\hline 64 & 0.0012000 & 0.28570 & 0.00080000 \\
\hline 65 & 0.00080000 & 0.23180 & 0.00090000 \\
\hline 66 & 0.0016000 & 0.36860 & $1.00000-04$ \\
\hline 67 & 0.036000 & 3.9346 & 0.00080000 \\
\hline 68 & & & \\
\hline 69 & $5010-05-02$ & Portsmouth & PB1/3001(3-4\%) \\
\hline 70 & 0.40180 & 47.234 & 0.036200 \\
\hline 71 & 0.23840 & 19.225 & 0.0000 \\
\hline 72 & 0.28010 & 38.025 & 0.028100 \\
\hline 73 & 1.0610 & 92.423 & 0.14480 \\
\hline 74 & 1.6556 & 92.315 & 0.016500 \\
\hline 75 & 0.22230 & 29.527 & 0.027100 \\
\hline 76 & 0.13750 & 12.832 & 0.0000 \\
\hline 77 & 0.00060000 & 0.19290 & 0.0028000 \\
\hline 78 & 0.41480 & 24.255 & $1.00000-04$ \\
\hline 79 & 0.0045000 & 0.70670 & 0.0010000 \\
\hline 80 & 0.0053000 & 0.75060 & 0.0048000 \\
\hline 81 & 0.0055000 & 0.84500 & 0.0022000 \\
\hline 82 & 0.17840 & 28.575 & 0.10720 \\
\hline 83 & 0.16330 & 26.425 & 0.094800 \\
\hline 84 & 0.17840 & 28.098 & 0.10020 \\
\hline 85 & & & \\
\hline 86 & $5010-06-02$ & Portsmouth & $326(97 \%)$ \\
\hline 87 & 0.26490 & 39.771 & 0.35190 \\
\hline 88 & 1.0059 & 91.827 & 0.21850 \\
\hline 89 & 1.2675 & 96.858 & 0.051600 \\
\hline 90 & 1.1680 & 89.160 & 0.13470 \\
\hline 91 & 0.25880 & 35.310 & 0.022400 \\
\hline 92 & 0.87550 & 81.914 & 0.28510 \\
\hline 93 & 0.045400 & 6.4717 & 0.032500 \\
\hline & & & \\
\hline 5 & & \\
\hline
\end{tabular}


AFTAC Portsmouth swipes (cont)

\begin{tabular}{|c|c|c|c|}
\hline & Atom\% U-234 & Atom\% U-235 & Alom\% U-236 \\
\hline 84 & 0.15260 & 26.979 & 0.12720 \\
\hline 95 & 0.19770 & 27.429 & 0.10270 \\
\hline 86 & 0.23400 & 32.374 & 0.030400 \\
\hline 07 & 0.34100 & 97.890 & 0.017600 \\
\hline 98 & 1.7699 & 06.391 & 0.022200 \\
\hline 99 & 2.2546 & 06.339 & 0.0093000 \\
\hline 100 & 2.1955 & 05.114 & 0.041800 \\
\hline 101 & 0.25780 & 23.141 & 0.025800 \\
\hline 102 & 0.14260 & 16.583 & 0.0085000 \\
\hline 103 & & & \\
\hline 104 & $5010-07-02$ & Portsmouth & $326(25 \%)$ \\
\hline 105 & 0.80830 & 55.850 & 0.071200 \\
\hline 106 & 0.19120 & 18.414 & 0.017600 \\
\hline 107 & & 14,417 & \\
\hline 108 & 0.067300 & 6.3067 & 0.00080000 \\
\hline 109 & 0.068200 & 6.2914 & 0.0018000 \\
\hline 110 & 0.35510 & 36.992 & 0.022500 \\
\hline 111 & 0.13200 & 11.458 & 0.0010000 \\
\hline 112 & 0.22330 & 36.672 & 0.10150 \\
\hline 113 & 0.24440 & 39.567 & 0.13050 \\
\hline 114 & 0.23890 & $\mathbf{3 7 . 7 0 7}$ & 0.11440 \\
\hline 115 & 0.45700 & 49.498 & 0.010600 \\
\hline 116 & 0.46790 & 52.628 & 0.031000 \\
\hline 117 & 0.14990 & 29.310 & 0.041800 \\
\hline 118 & 0.22400 & 30.377 & 0.10440 \\
\hline 119 & 1.5989 & 79.854 & 0.017500 \\
\hline 120 & & $\cdots$ & \\
\hline 121 & S010-08-02 & Portsmouth & 326 (97\%) \\
\hline .122 & 0.60510 & 41234 & 0.035500 \\
\hline 123 & 0.89280 & 60.013 & 0.031000 \\
\hline 124 & 0.23510 & 32.235 & 0.026100 \\
\hline 125 & 0.11600 & 9.3042 & 0.0040000 \\
\hline 126 & 0.065100 & 6.0430 & 0.00020000 \\
\hline 127 & 0.12930 & 11.611 & 0.00070000 \\
\hline 128 & 0.074300 & 6.7299 & \\
\hline 129 & 1.2438 & 80.730 & 0.069600 \\
\hline 130 & 1.7619 & 07.211 & 0.015100 \\
\hline 131 & 1.7222 & 86.193 & 0.017400 \\
\hline 132 & 0.88850 & 81.960 & 0.26080 \\
\hline 133 & 2.0337 & 06.867 & 0.016300 \\
\hline 134 & 0.22820 & 18.410 & 0.019700 \\
\hline 135 & 0.098000 & 10.634 & 0.0079000 \\
\hline 136 & 1.9784 & 95.653 & 0.012600 \\
\hline 137 & 2.0806 & 96.703 & 0.015100 \\
\hline 138 & 0.32310 & 28.933 & 0.0015000 \\
\hline
\end{tabular}


AFTAC Portsmouth pine needles

\begin{tabular}{|c|c|c|c|}
\hline & Atom\% U-234 & Atom\% U.235 & Atom\% U-236 \\
\hline \multicolumn{4}{|l|}{ of } \\
\hline 1 & Vo10-09-01 & Portsmouth : & Pine noedlo $(5 \mathrm{~km})$ \\
\hline 2 & 0.0057000 & 0.71020 & 0.0000 \\
\hline 3 & 0.0029000 & 0.71400 & 0.0000 \\
\hline 4 & 0.0054000 & 0.70090 & 0.00030000 \\
\hline 5 & 0.0026000 & 0.52770 & $1.00000-04$ \\
\hline \multicolumn{4}{|c|}{$6 \quad \square$} \\
\hline 7 & V010-10-01 & Portsmouth & Pine noedle $(3 \mathrm{~km})$ \\
\hline 8 & 0.0061000 & 0.72830 & 0.0000 \\
\hline 9 & 0.0046000 & 0.70920 & 0.0000 \\
\hline 10 & 0.0031000 & 0.69510 & 0.0000 \\
\hline 11 & 0.0042000 & 0.72250 & 0.00020000 \\
\hline 12 & 0.0032000 & 0.72180 & 0.0000 \\
\hline 13 & 0.0095000 & 0.73180 & 0.0000 \\
\hline 14 & 0.0055000 & 0.71990 & 0.0000 \\
\hline 15 & 0.0031000 & 0.70950 & 0.0000 \\
\hline \multicolumn{4}{|c|}{$\begin{array}{ll}16 \\
\end{array}$} \\
\hline 17 & V010-11-01 & Portsmouth & Pino noodlo (1 km) \\
\hline 18 & 0.0052000 & 0.71040 & 0.0000 \\
\hline 19 & 0.0023000 & 0.71010 & 0.0000 \\
\hline 20 & 0.0053000 & 0.70270 & \\
\hline 21 & 0.0031000 & 0.73870 & 0.0000 \\
\hline 22 & 0.0059000 & 0.72110 & 0.0000 \\
\hline \multicolumn{4}{|c|}{\begin{tabular}{l|l}
23 & $\because$
\end{tabular}} \\
\hline 24 & V010-12-01 & Portsmouth & Pine needle (0 km) \\
\hline 25 & 0.035300 & 6.0350 & 0.046200 \\
\hline 26 & 0.089400 & 7.3571 & 0.0051000 \\
\hline 27 & 0.85490 & 53.631 & \\
\hline 28 & 0.22030 & 23.025 & 0.072000 \\
\hline 29 & 1.1722 & 75.150 & 0.068500 \\
\hline 30 & 0.087600 & 7.0781 & 0.0059000 \\
\hline 31 & 0.23360 & 17.483 & 0.033200 \\
\hline 32 & 0.13580 & 11.470 & 0.014600 \\
\hline 33 & 0.090400 & 7.1089 & 0.0056000 \\
\hline 34 & 0.22670 & 24.676 & 0.024400 \\
\hline 35 & 0.10000 & 7.4856 & \\
\hline 36 & 0.96490 & 62.433 & 0.047800 \\
\hline 37 & 0.16180 & 17.257 & 0.10710 \\
\hline
\end{tabular}


31

AFTAC Paducah swipes

\begin{tabular}{|c|c|c|c|}
\hline & Atom\% U-234 & Atom\% U-235 & Atom $\%$ L1236 \\
\hline 0 & & & \\
\hline 1 & S009-01-01/Paducah & Building C315 (0.3\%) & \\
\hline 2 & 0.0013000 & 0.29180 & $3.00000-05$ \\
\hline 3 & 0.0015000 & 0.30380 & 0.0016200 \\
\hline 4 & 0.0014000 & 0.29310 & 0.0029300 \\
\hline 5 & 0.0042000 & 0.68440 & $1.00000-05$ \\
\hline 6 & 0.0014000 & 0.30660 & 0.0013100 \\
\hline 7 & 0.0026000 & 0.43280 & 0.0000 \\
\hline 8 & 0.0063000 & 0.83460 & 0.00020000 \\
\hline 9 & 0.0063000 & 0.83460 & 0.00020000 \\
\hline 10 & 0.0014000 & 0.29940 & $2.00000-05$ \\
\hline 11 & 0.0023000 & 0.40840 & 0.00028000 \\
\hline 12 & & 0.31020 & 0.0017300 \\
\hline 13 & 0.0018000 & 0.34440 & 0.00025000 \\
\hline 14 & 0.0013000 & 0.29050 & 0.0025500 \\
\hline 15 & 0.0013000 & 0.28980 & 0.0025200 \\
\hline 16 & 0.0042000 & 0.70680 & 0.0027100 \\
\hline 17 & 0.0057000 & 0.85530 & 0.00044000 \\
\hline 18 & 0.0079000 & 1.0772 & $8.00000-05$ \\
\hline 19 & 0.0040000 & 0.61340 & 0.0024600 \\
\hline 20 & 0.0056000 & 0.84950 & 0.0015900 \\
\hline 21 & 0.0039000 & 0.59250 & 0.0048900 \\
\hline 22 & 0.0052000 & 0.67990 & 0.0070600 \\
\hline 23 & 0.0024000 & 0.50660 & 0.00026000 \\
\hline 24 & 0.0038000 & 0.71800 & \\
\hline 25 & 0.0048000 & 0.72940 & 0.0000 \\
\hline 26 & 0.0054000 & 0.77820 & 0.0062800 \\
\hline 27 & 0.0021000 & 0.38790 & 0.00082000 \\
\hline 28 & 0.00070000 & 0.20200 & 0.0024700 \\
\hline 29 & 0.0044000 & 0.67900 & 0.0034000 \\
\hline 30 & 0.0065000 & 0.86070 & \\
\hline 31 & 0.0065000 & 0.98570 & 0.00020000 \\
\hline 32 & & & 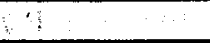 \\
\hline 33 & S009-02-01/Paducah & RA sign near C310 & \\
\hline 34 & 0.0053000 & 0.72510 & 0.0000 \\
\hline 35 & 0.0055000 & 0.71840 & $4.00000-05$ \\
\hline 36 & 0.0053000 & 0.72250 & 0.0019900 \\
\hline 37 & 0.00070000 & 0.20340 & 0.0021800 \\
\hline 38 & 0.0052000 & 0.71690 & $3.00000-05$ \\
\hline 39 & 0.0054000 & 0.72190 & 0.0026600 \\
\hline 40 & 0.0017000 & 0.30850 & 0.0037100 \\
\hline 41 & 0.0052000 & 0.65910 & 0.012820 \\
\hline 42 & 0.0053000 & 0.64160 & 0.012320 \\
\hline 43 & 0.0054000 & 0.71600 & 0.0015300 \\
\hline 44 & 0.0054000 & 0.71710 & 0.0014100 \\
\hline \multicolumn{4}{|l|}{45} \\
\hline 46 & S009-03-01/Paducah & Building C333A. & Normal $(0.72 \%)$ \\
\hline
\end{tabular}


32

AFTAC Paducah swipes (cont)

\begin{tabular}{|c|c|c|c|}
\hline & Alom\% U-234 & Atom\% U-235 & Atom \% U-236 \\
\hline 47 & 0.0038000 & 0.60140 & 0.0038000 \\
\hline 48 & 0.0045000 & 0.57420 & 0.0033500 \\
\hline 49 & 0.0024000 & 0.49680 & \\
\hline 60 & 0.010200 & 1.2213 & 0.00015000 \\
\hline 51 & 0.0016000 & 0.32520 & 0.00022000 \\
\hline 52 & 0.0056000 & 0.65770 & 0.0087400 \\
\hline 53 & 0.0040000 & 0.59820 & 0.0048600 \\
\hline 54 & 0.0054000 & 0.71730 & 0.0000 \\
\hline 55 & 0.0049000 & 0.70830 & 0.0000 \\
\hline 56 & 0.0030000 & 0.51110 & 0.0023100 \\
\hline 57 & 0.0016000 & 0.33700 & $3.00000-05$ \\
\hline 58 & 0.0018000 & 0.33760 & 0.00049000 \\
\hline 59 & 0.0024000 & 0.41340 & 0.00015000 \\
\hline 60 & 0.0052000 & 0.71660 & 0.0000 \\
\hline 61 & 0.012400 & 1.5156 & 0.00036000 \\
\hline \multicolumn{4}{|c|}{$\begin{array}{ll}62 & \vdots \\
\end{array}$} \\
\hline 63 & S009-04-01/Paducah & $\cos 31(-1 \%)$ & \\
\hline 64 & 0.0016000 & 0.33280 & 0.00040000 \\
\hline 65 & 0.0052000 & 0.64370 & 0.012570 \\
\hline 66 & 0.0033000 & 0.50620 & $5.000000-05$ \\
\hline 67 & 0.0024000 & 0.43610 & $1.00000-05$ \\
\hline 68 & 0.0072000 & 0.96020 & 0.00037000 \\
\hline 69 & 0.0048000 & 0.69270 & 0.00016000 \\
\hline 70 & 0.0080000 & 1.0487 & 0.0044600 \\
\hline 71 & 0.0014000 & 0.31100 & 0.0000 \\
\hline 72 & 0.0021000 & 0.36680 & 0.00059000 \\
\hline 73 & 0.0013000 & 0.29390 & 0.00085000 \\
\hline 74 & 0.0041000 & 0.63270 & 0.00016000 \\
\hline 75 & 0.0065000 & 0.80000 & 0.00067000 \\
\hline 76 & 0.0030000 & 0.53820 & 0.00052000 \\
\hline 77 & 0.0050000 & 0.74780 & 0.00028000 \\
\hline 78 & 0.0057000 & 0.80400 & 0.00088000 \\
\hline 79 & 0.0078000 & 1.0770 & 0.0018800 \\
\hline 80 & 0.0052000 & 0.72680 & 0.0013500 \\
\hline $8 !$ & 0.0062000 & 0.86600 & 0.0012100 \\
\hline 82 & 0.0040000 & 0.70070 & 0.00016000 \\
\hline 83 & 0.0054000 & 0.76110 & 0.00087000 \\
\hline 84 & 0.0062000 & 0.87840 & 0.0012000 \\
\hline \multicolumn{4}{|c|}{85} \\
\hline 86 & S009-05-01/Paducah & $\operatorname{C310}(1.8-2.1 \%)$ & \\
\hline 87 & 0.016600 & 1.9136 & 0.0015300 \\
\hline 88 & 0.0048000 & 0.78550 & 0.00022000 \\
\hline 89 & 0.013900 & 1.6291 & $4.00000-05$ \\
\hline 90 & 0.0047000 & $0.658 B 0$ & 0.00096000 \\
\hline 91 & 0.0029000 & 0.45180 & 0.00021000 \\
\hline 92 & 0.0045000 & 0.62430 & 0.0051100 \\
\hline 93 & 0.015800 & 1.8565 & $200000-05$ \\
\hline
\end{tabular}


33

AFTAC Paducah swipes (cont)

\begin{tabular}{|c|c|c|c|c|}
\hline & & Atom\% U-234 & Atom\% 4225 & Atom \% U-236 \\
\hline & 24 & 0.015600 & 1.7785 & $5.00000-05$ \\
\hline & 85 & 0.0058000 & 0.86980 & 0.0023900 \\
\hline & 86 & 0.016500 & 1.2001 & $3.00000-05$ \\
\hline 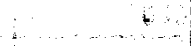 & 87 & 0.016600 & 1.8232 & 0.0000 \\
\hline & 28 & 0.015300 & 1.7310 & $6.00000-05$ \\
\hline & 89 & 0.016500 & 1.9083 & 0.0000 \\
\hline & 100 & 0.016600 & 1.9195 & $1.00000-05$ \\
\hline & 101 & 0.016500 & 1.9184 & 0.0000 \\
\hline & 102 & 0.015700 & 1.8382 & $4.00000-05$ \\
\hline & 103 & 0.016600 & 1.8173 & 0.0000 \\
\hline & 104 & 0.015900 & 1.8102 & $2.00000-05$ \\
\hline & 105 & 0.0017000 & 0.33790 & 0.00033000 \\
\hline
\end{tabular}


AFTAC Paducah pine needles

\begin{tabular}{|c|c|c|c|}
\hline & Atom\% U-234 & Atom\% U-235 & Atom\% U-236 \\
\hline 0 & & & \\
\hline 1 & Vo09-06-01/Paducah & Pine noedie (8 km) & \\
\hline 2 & 0.0053000 & 0.72080 & 0.0000 \\
\hline 3 & 0.0044000 & 0.72310 & 0.0000 \\
\hline 4 & 0.0048000 & 0.71120 & 0.00039000 \\
\hline 5 & 0.0057000 & 0.73160 & 0.00013000 \\
\hline 6 & 0.0057000 & 0.70640 & 0.0000 \\
\hline 7 & 0.0040000 & 0.70360 & $\vdots$ \\
\hline 8 & 0.0061000 & 0.68840 & 0.0000 \\
\hline 9 & 0.0042000 & 0.73020 & 0.00050000 \\
\hline 10 & 0.0046000 & 0.71520 & 0.0000 \\
\hline 11. & 0.0053000 & 0.71850 & 0.0000 \\
\hline 12 & & 0.72230 & \\
\hline 13 & 0.0045000 & 0.71070 & 0.00013000 \\
\hline \multicolumn{4}{|l|}{14} \\
\hline 15 & V009-08-01/Paducah & Pine needle $(3 \mathrm{~km})$ & \\
\hline 16 & 0.0044000 & 0.72010 & $1.00000-05$ \\
\hline 17 & 0.0055000 & 0.71780 & $5.00000-05$ \\
\hline 18 & 0.0055000 & 0.72280 & 0.0000 \\
\hline 10 & 0.0052000 & 0.71970 & $7.00000-05$ \\
\hline 20 & 0.037500 & 4.0908 & 0.00075000 \\
\hline 21 & 0.0055000 & 0.72110 & 0.0000 \\
\hline 22 & 0.0056000 & 0.70830 & 0.0000 \\
\hline 23 & 0.0050000 & 0.72470 & 0.00026000 \\
\hline 24 & 0.0055000 & 0.72310 & 0.0000 \\
\hline 25 & 0.014600 & 1.7110 & 0.00028000 \\
\hline \multicolumn{4}{|l|}{26} \\
\hline 27 & V009-09-01/Paducah & Pine needle $(1 \mathrm{~km})$ & \\
\hline 28 & 0.0056000 & 0.72790 & 0.0000 \\
\hline 29 & 0.0049000 & 0.71530 & 0.0000 \\
\hline 30 & 0.0053000 & 0.73080 & 0.0000 \\
\hline 31 & 0.0038000 & 0.71220 & 0.0000 \\
\hline 32 & 0.0054000 & 0.69920 & 0.00039000 \\
\hline 33 & 0.0052000 & 0.72050 & 0.0000 \\
\hline 34 & & 0.71320 & \\
\hline 35 & 0.0057000 & 0.71560 & 0.0000 \\
\hline 36 & 0.0045000 & 0.71540 & 0.00015000 \\
\hline 37 & 0.0045000 & 0.71920 & \\
\hline 38 & 0.0055000 & 0.72950 & \\
\hline 39 & 0.0045000 & 0.73230 & 0.0000 \\
\hline 40 & 0.0060000 & 0.72640 & 0.00029000 \\
\hline 41 & 0.0052000 & 0.71250 & $1.00000-05$ \\
\hline 42 & 0.015600 & 1.7925 & $5.00000-05$ \\
\hline \multicolumn{4}{|l|}{43} \\
\hline 44 & Voo9-10-01/Paducah & Pine needle (0 km) & \\
\hline 45 & 0.0049000 & 0.72010 & 0.0000 \\
\hline
\end{tabular}




\section{Appendix 3}

COMPARISON OF BULK AND PARTICULATE DATA FROM SWIPE SAMPLES TAKEN DURING THE PORTSMOUTH FIEID TRIAL 

Portsmouth

330 Bullding $(<0.4 \%)$

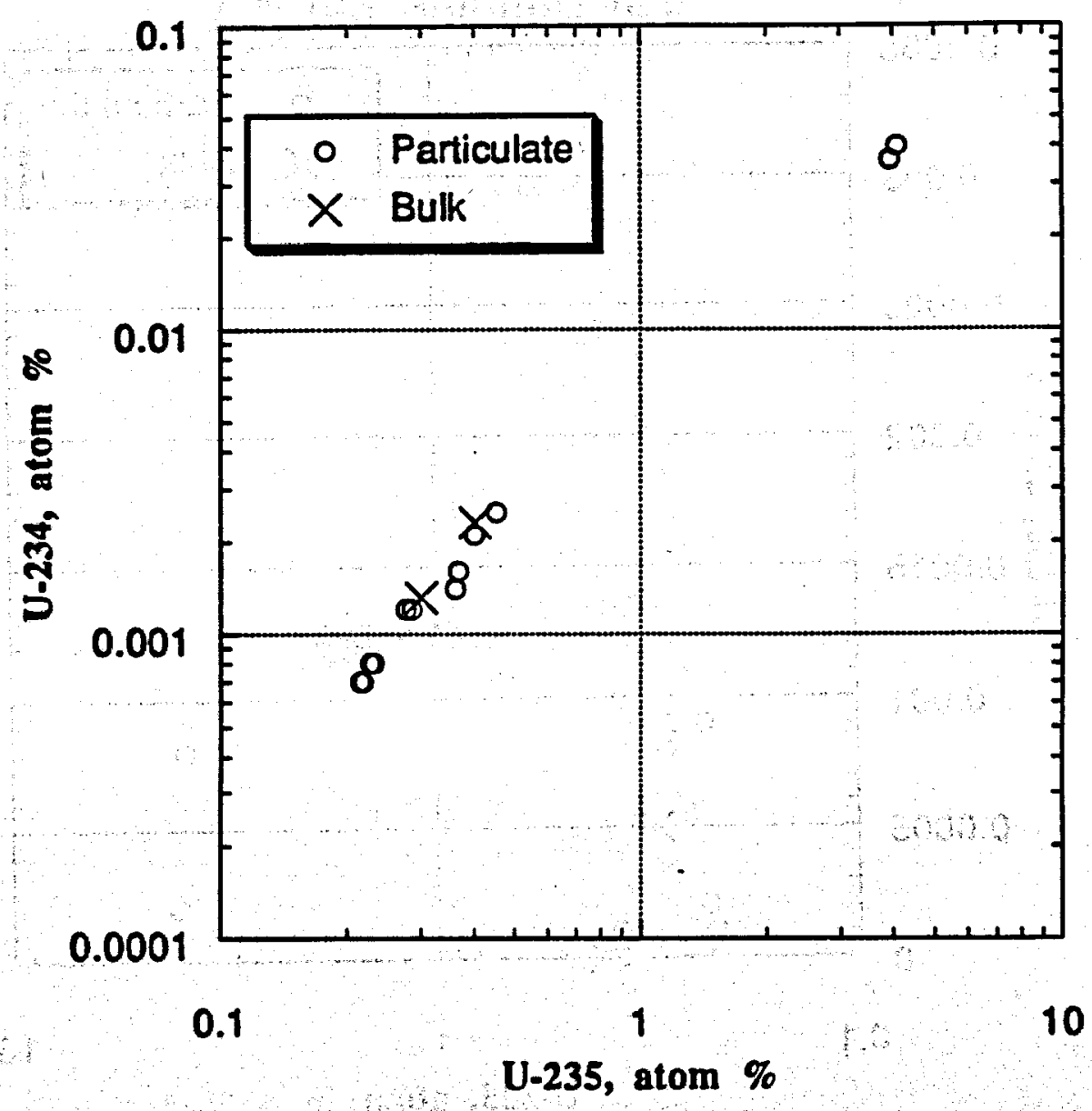




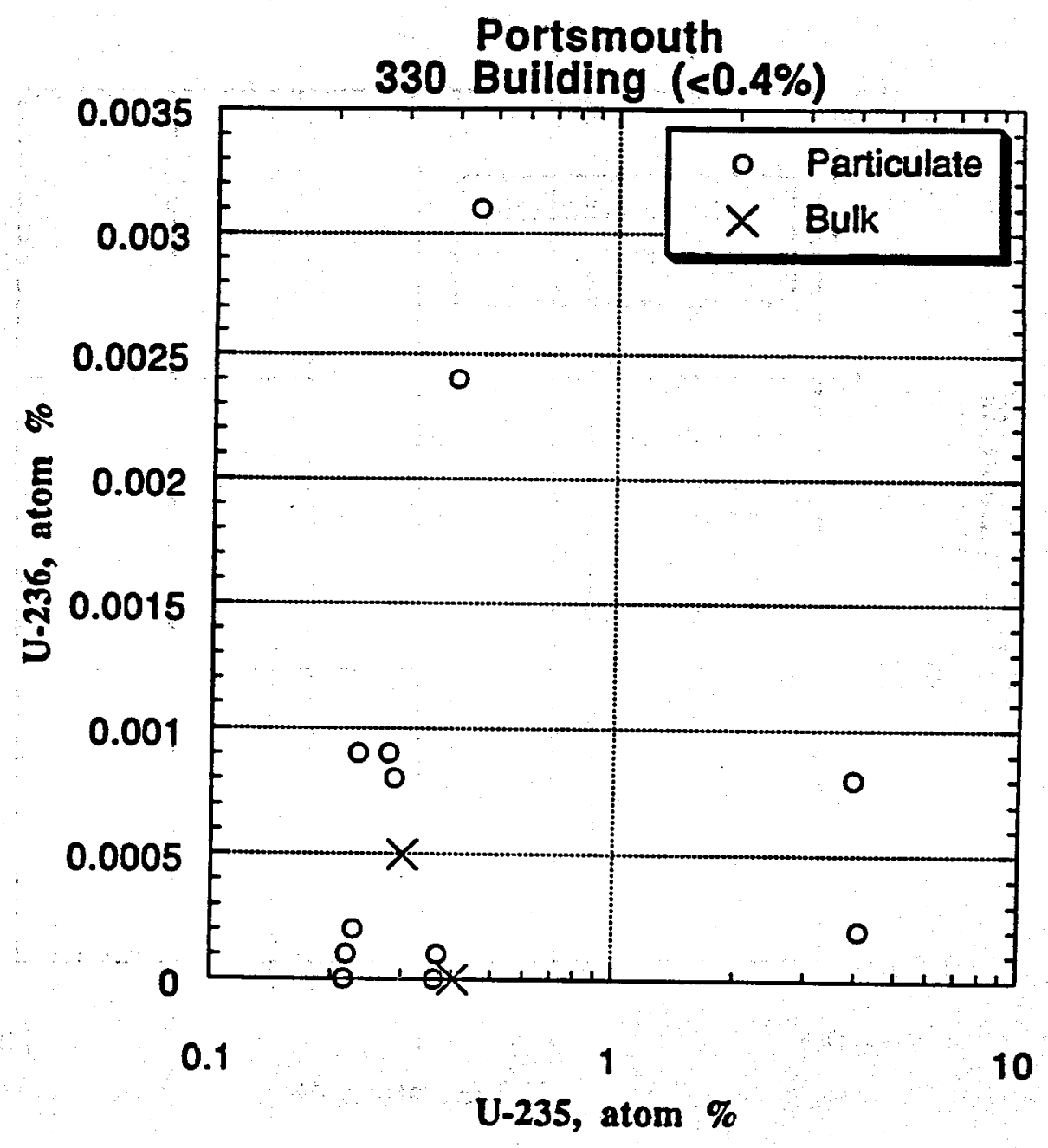




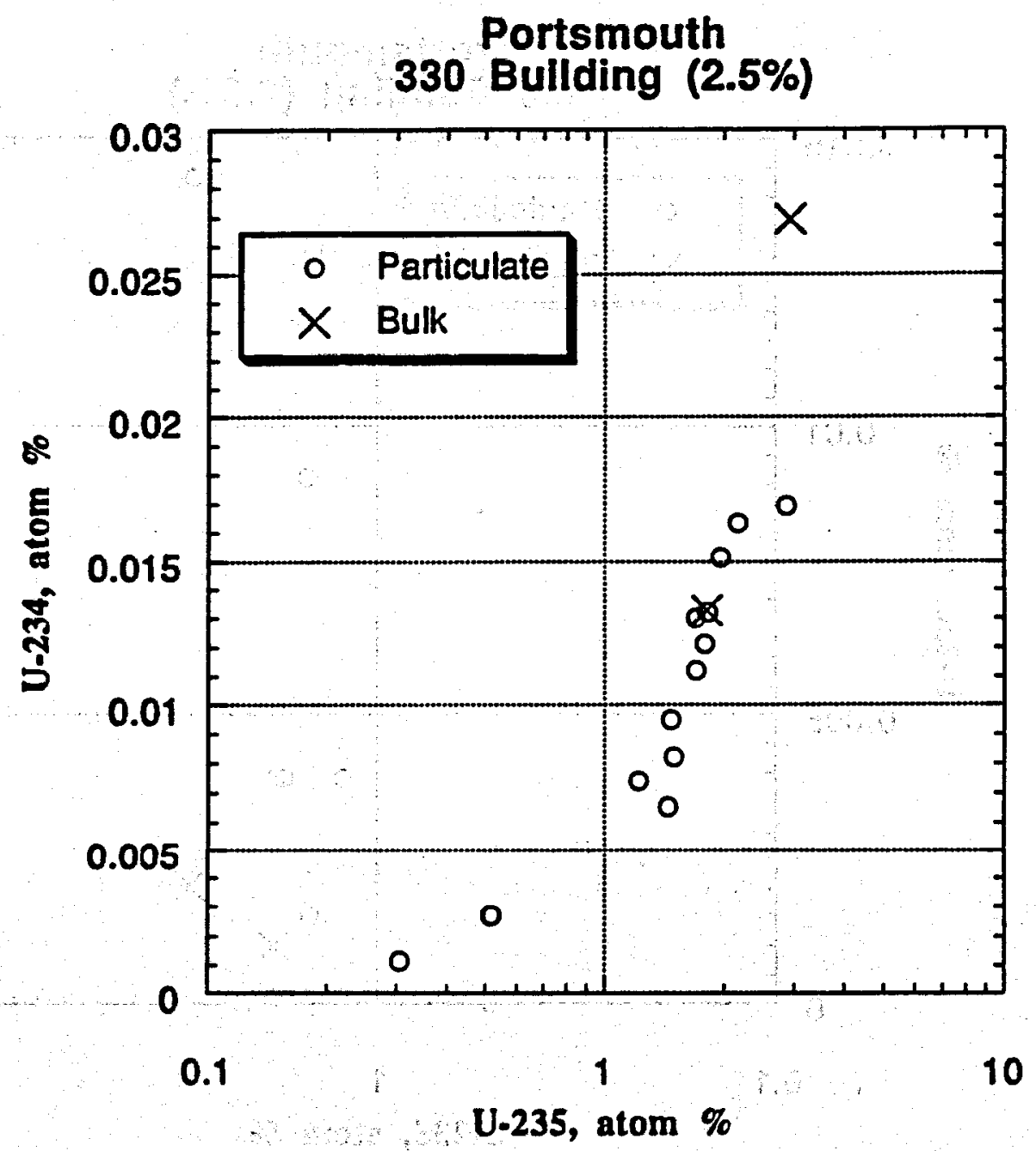




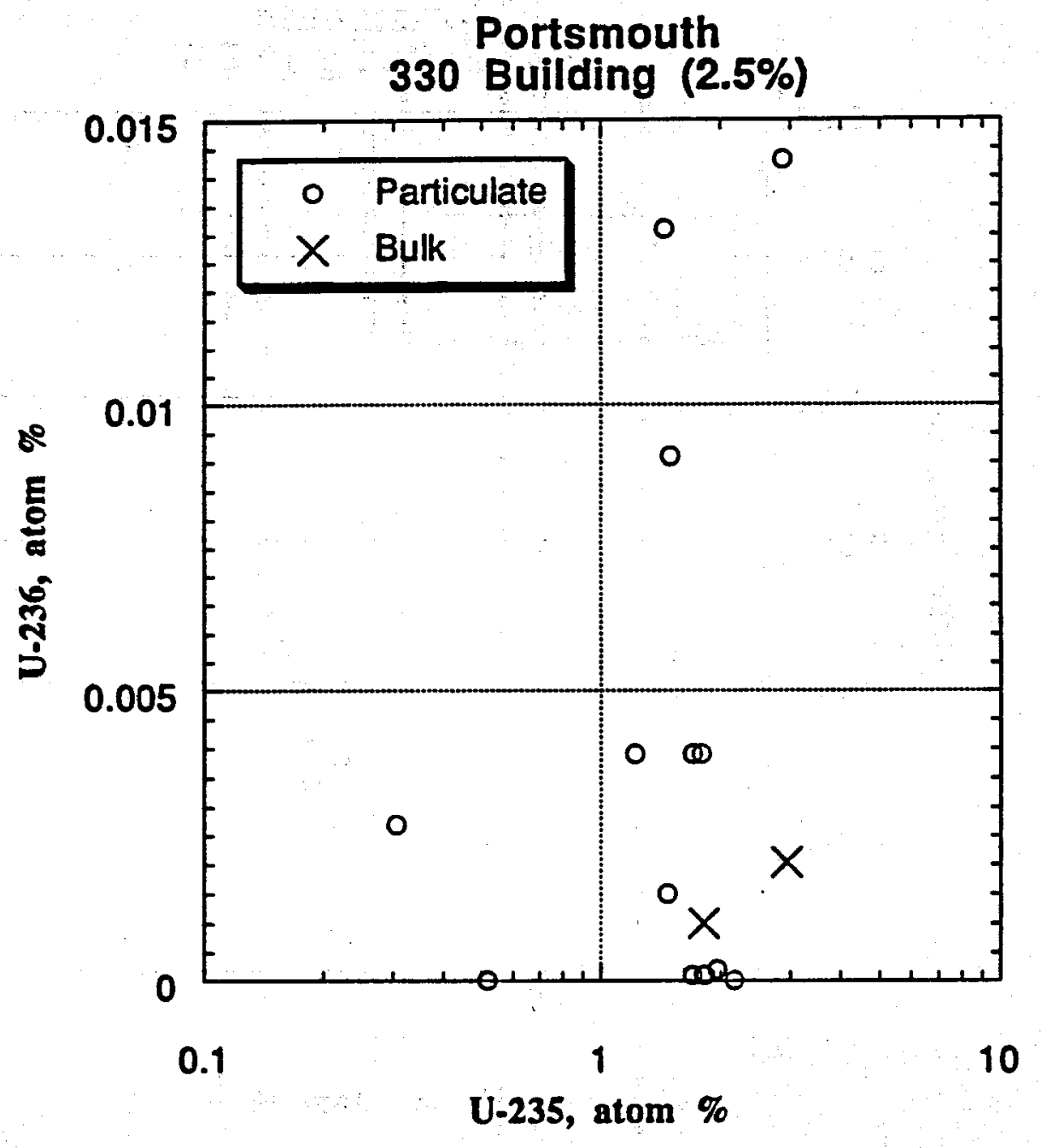




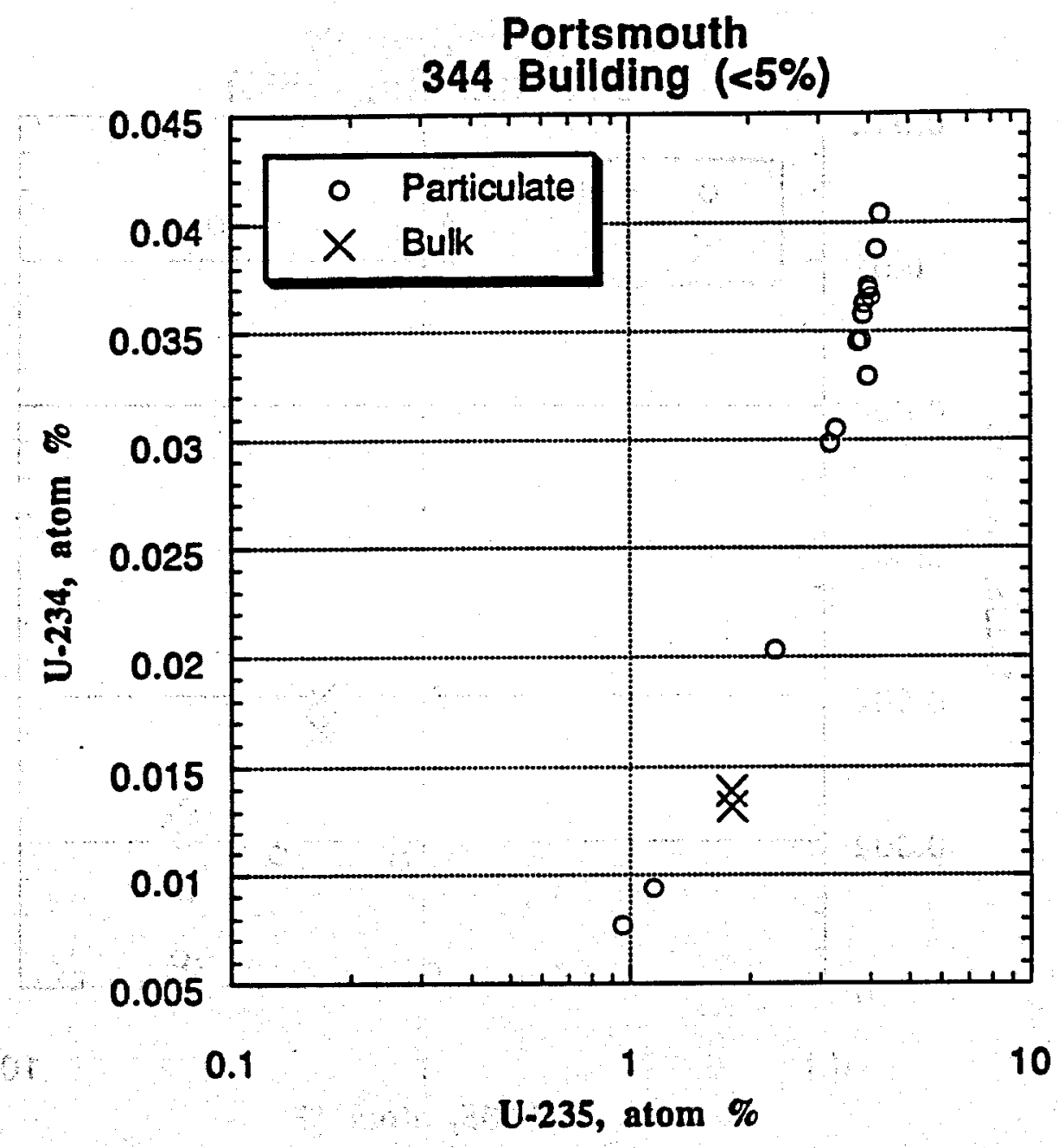




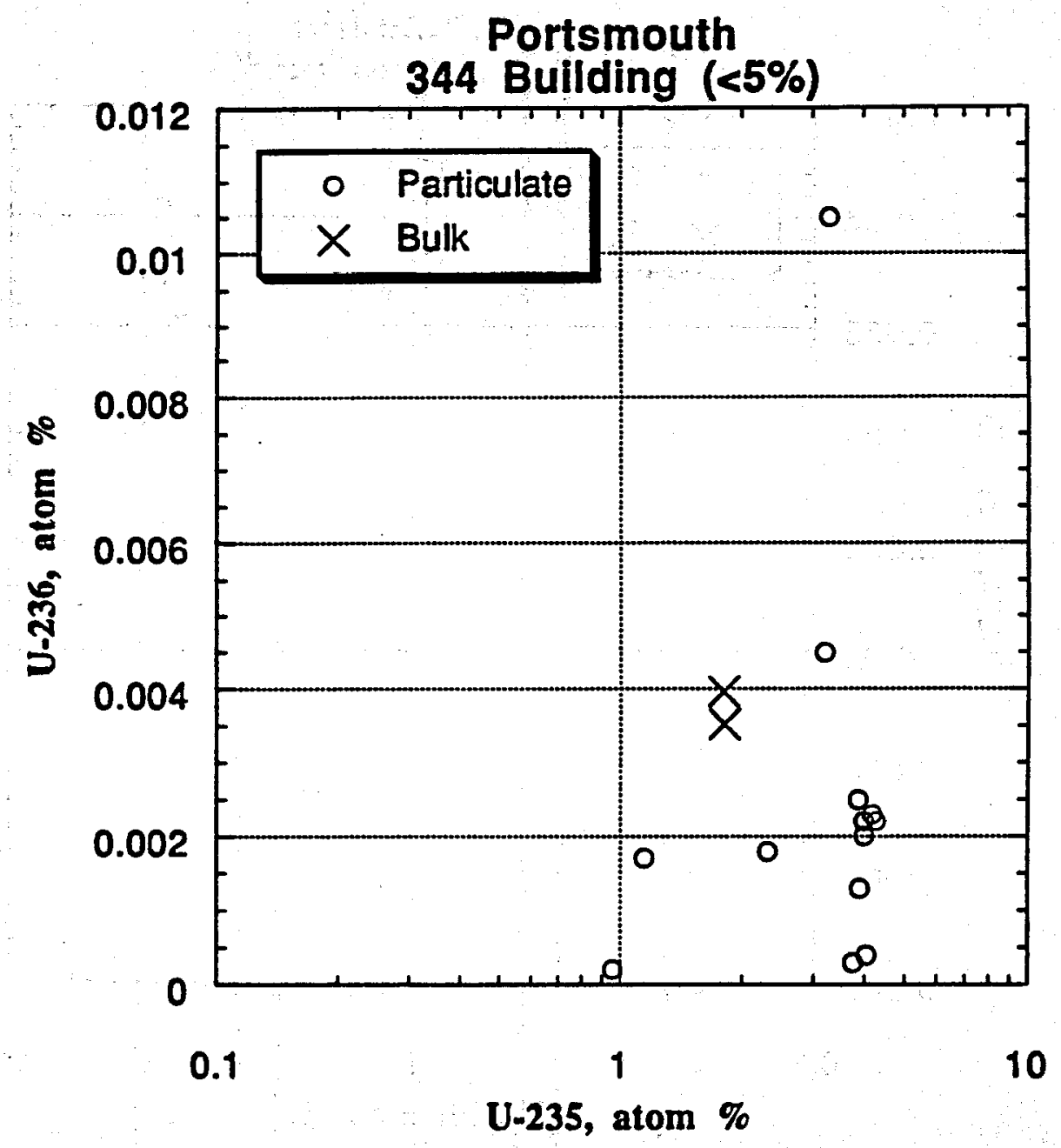




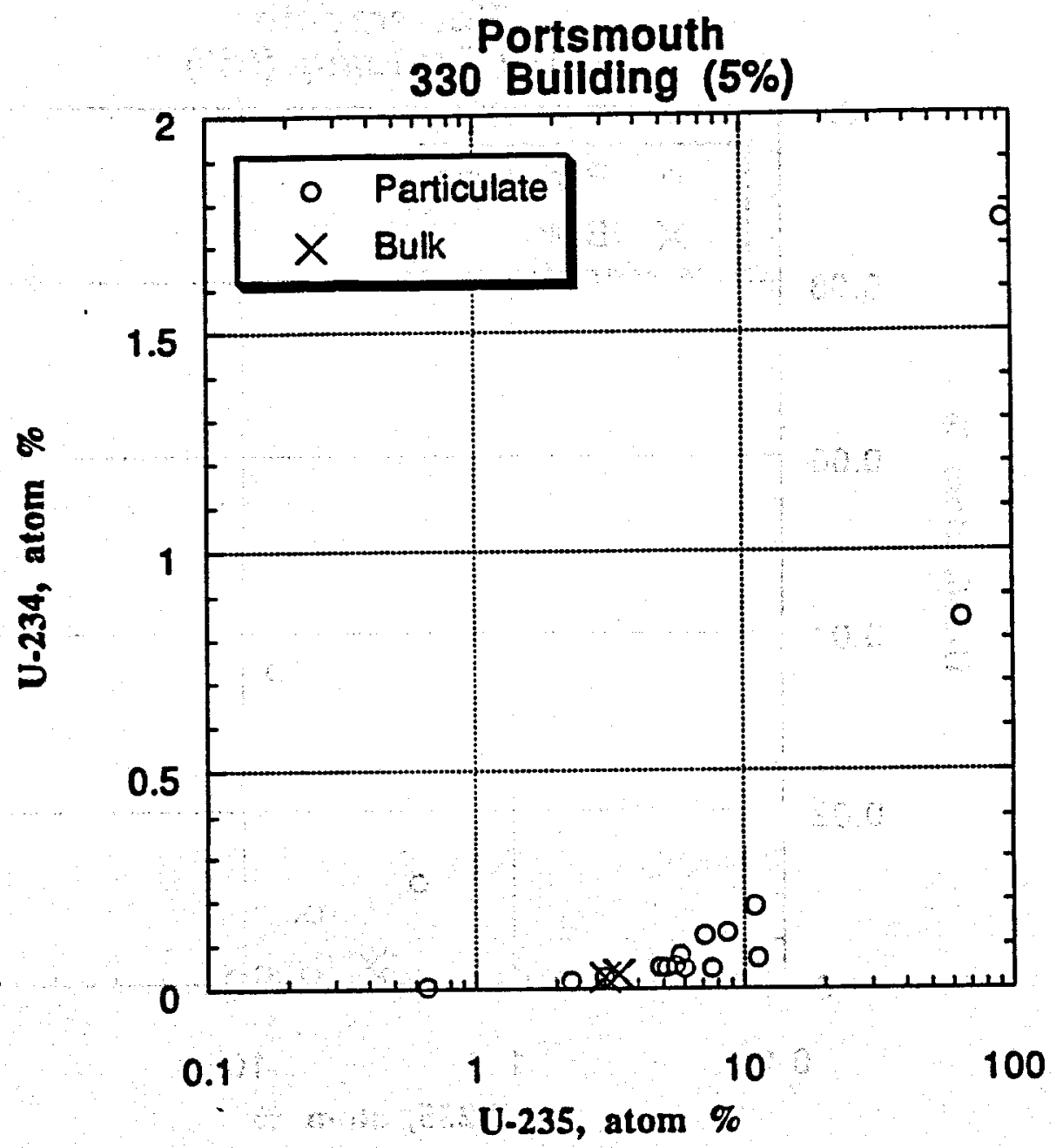




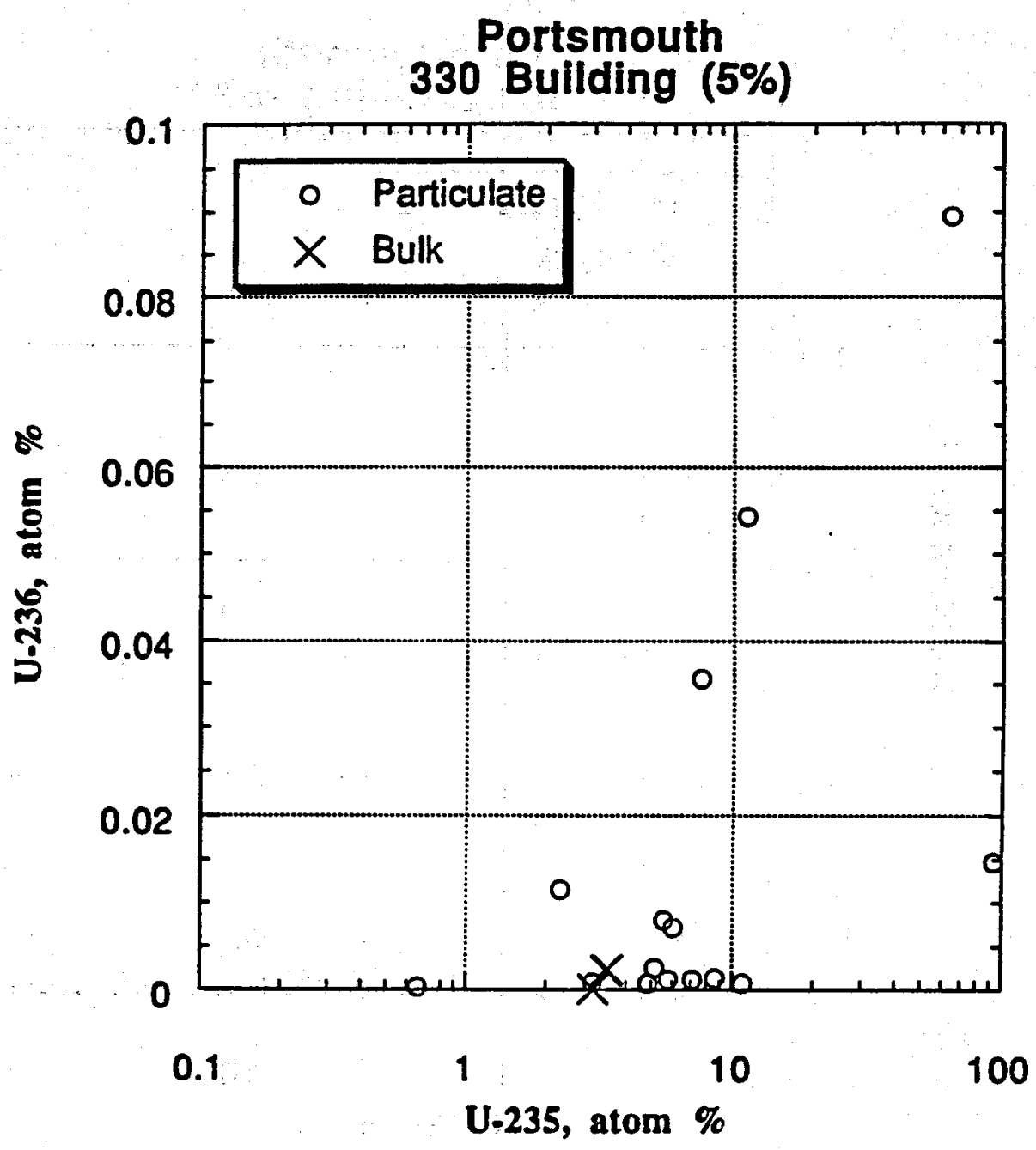


Portsmouth

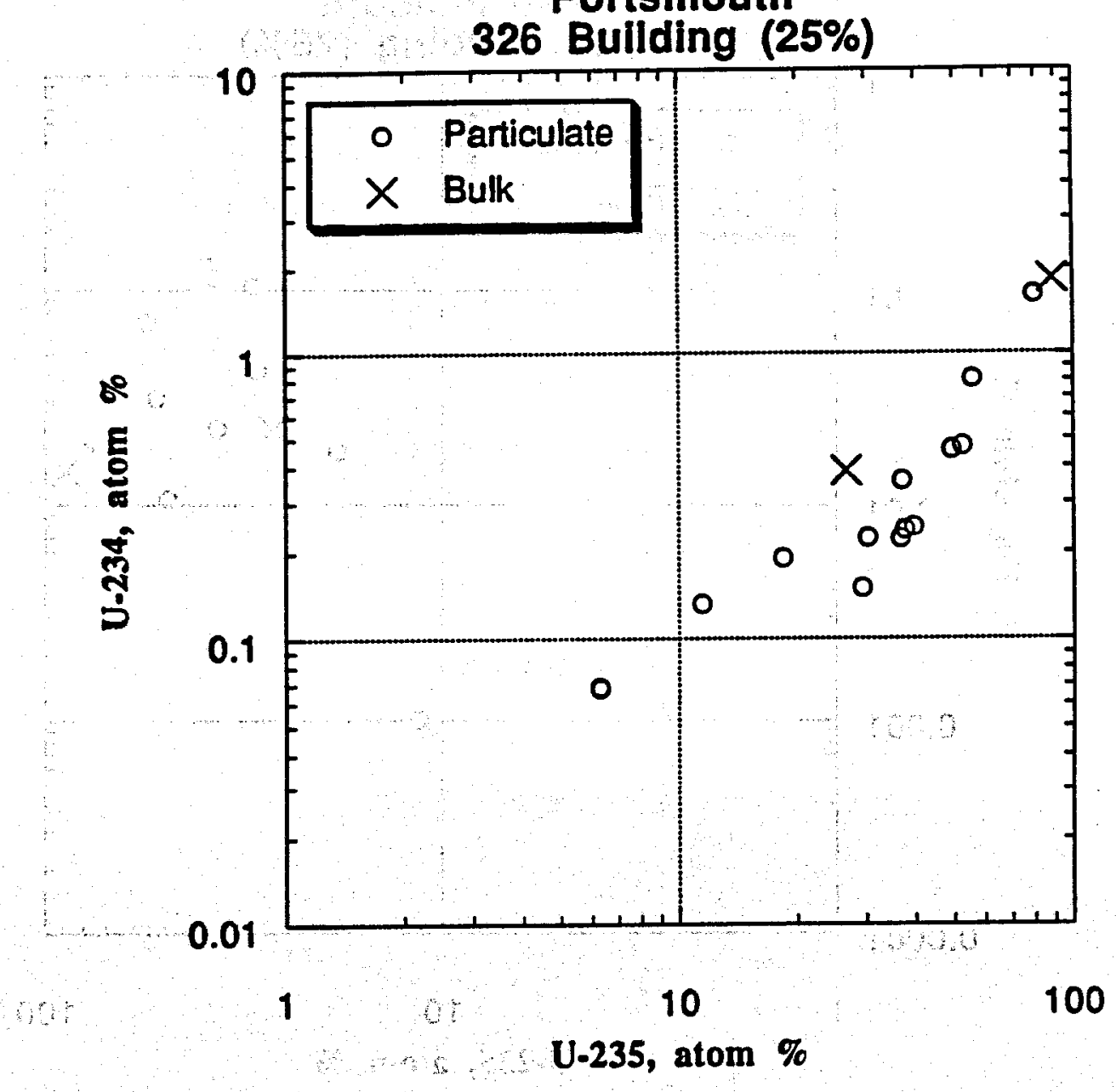




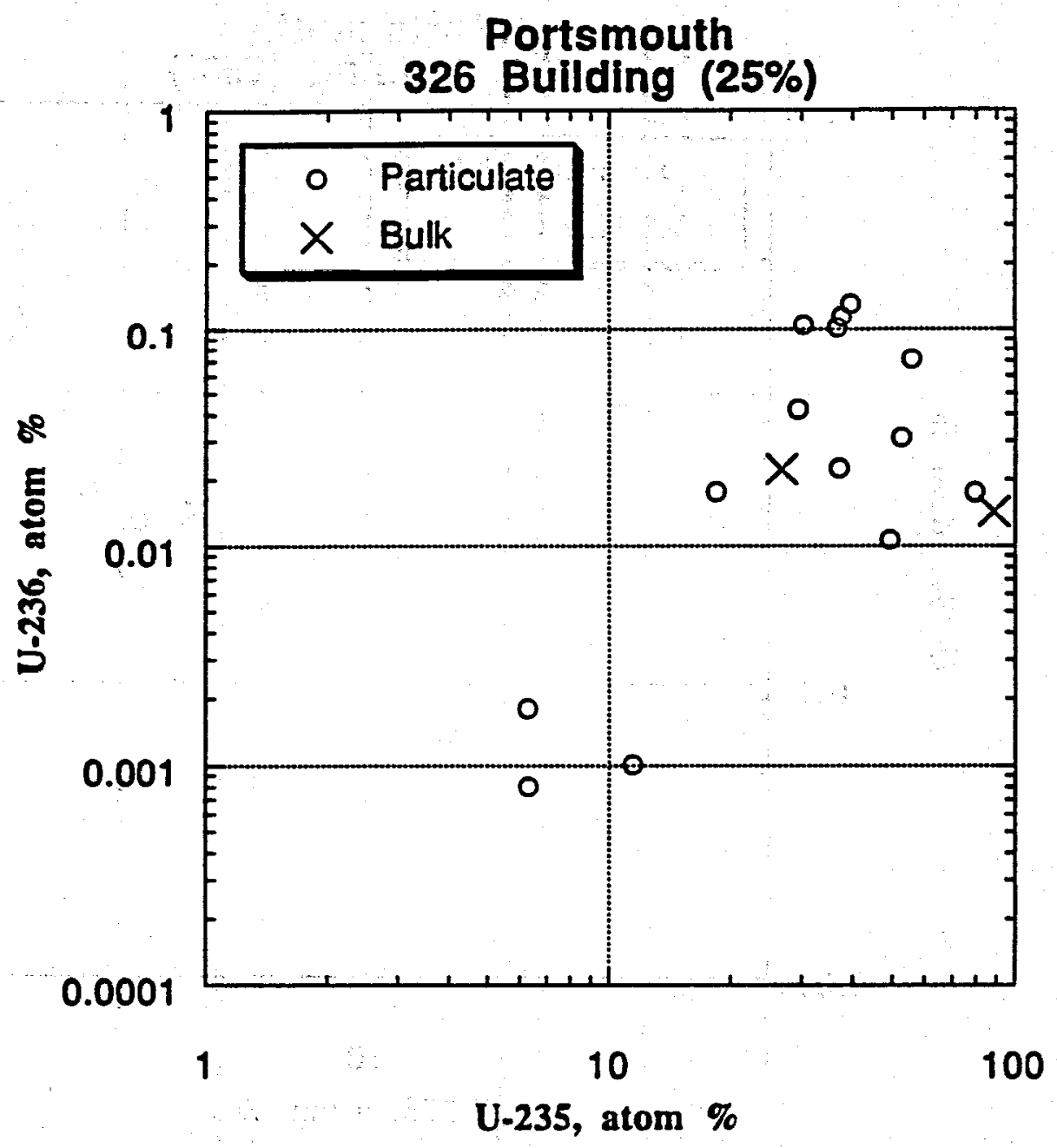




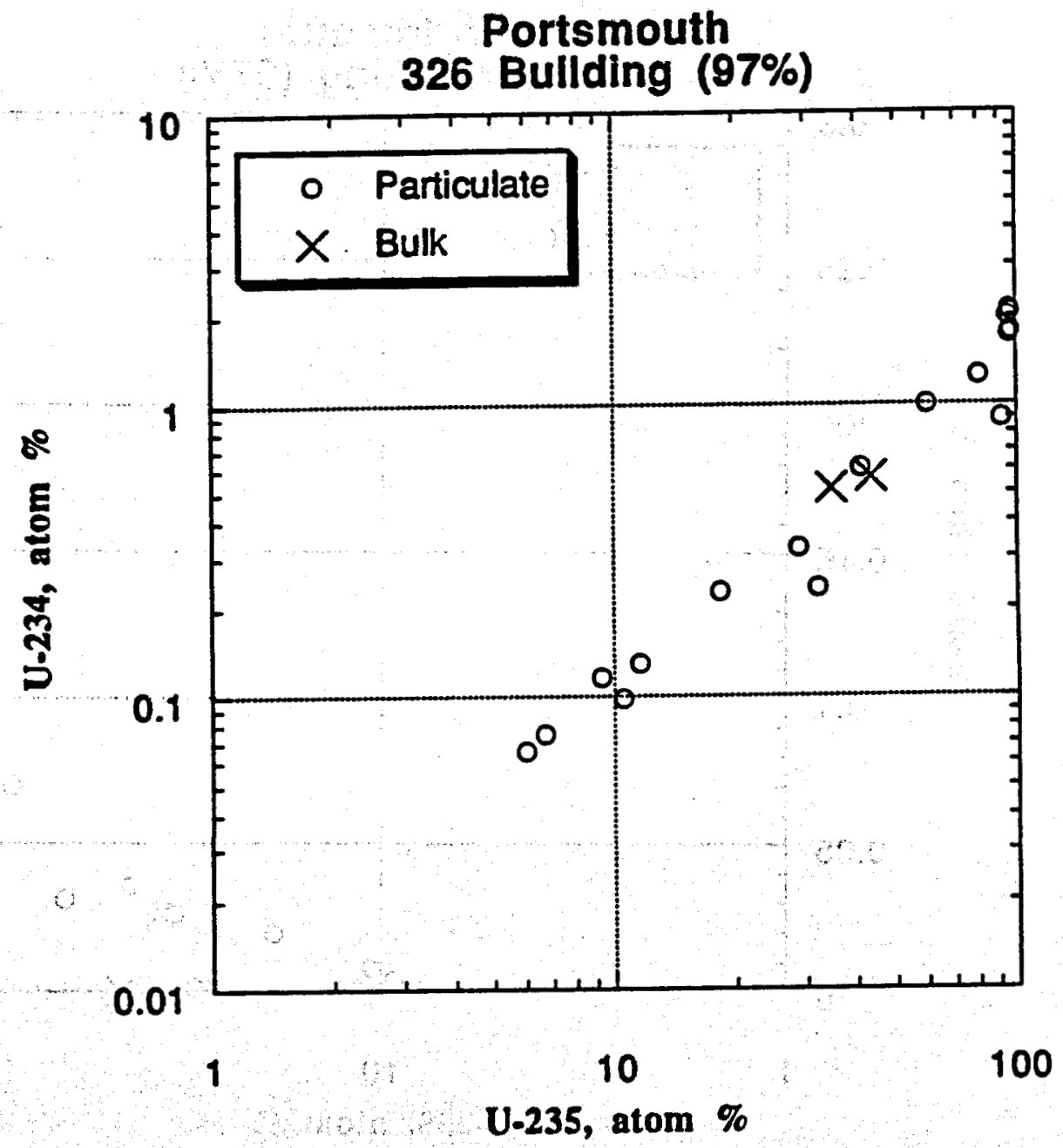




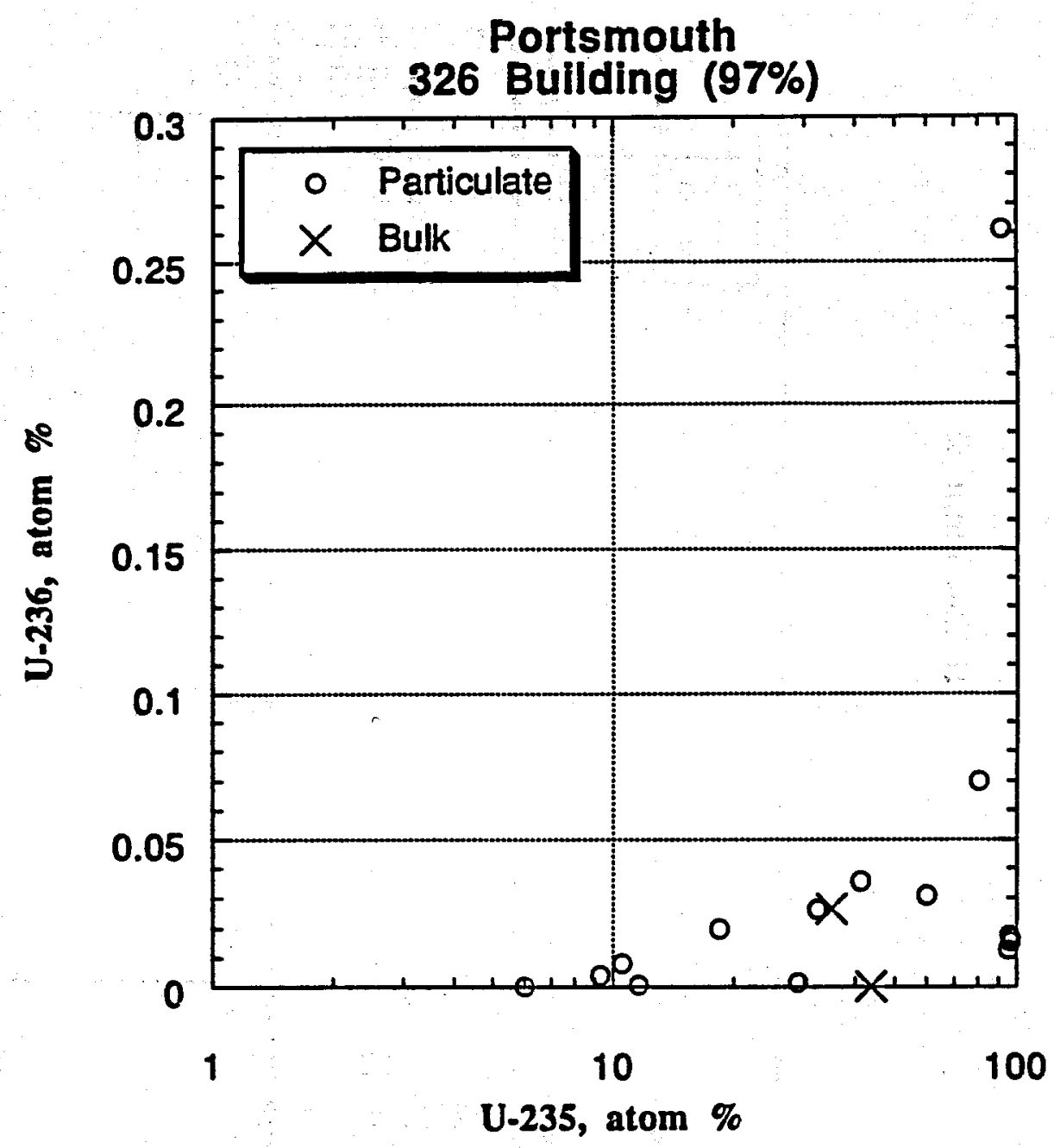




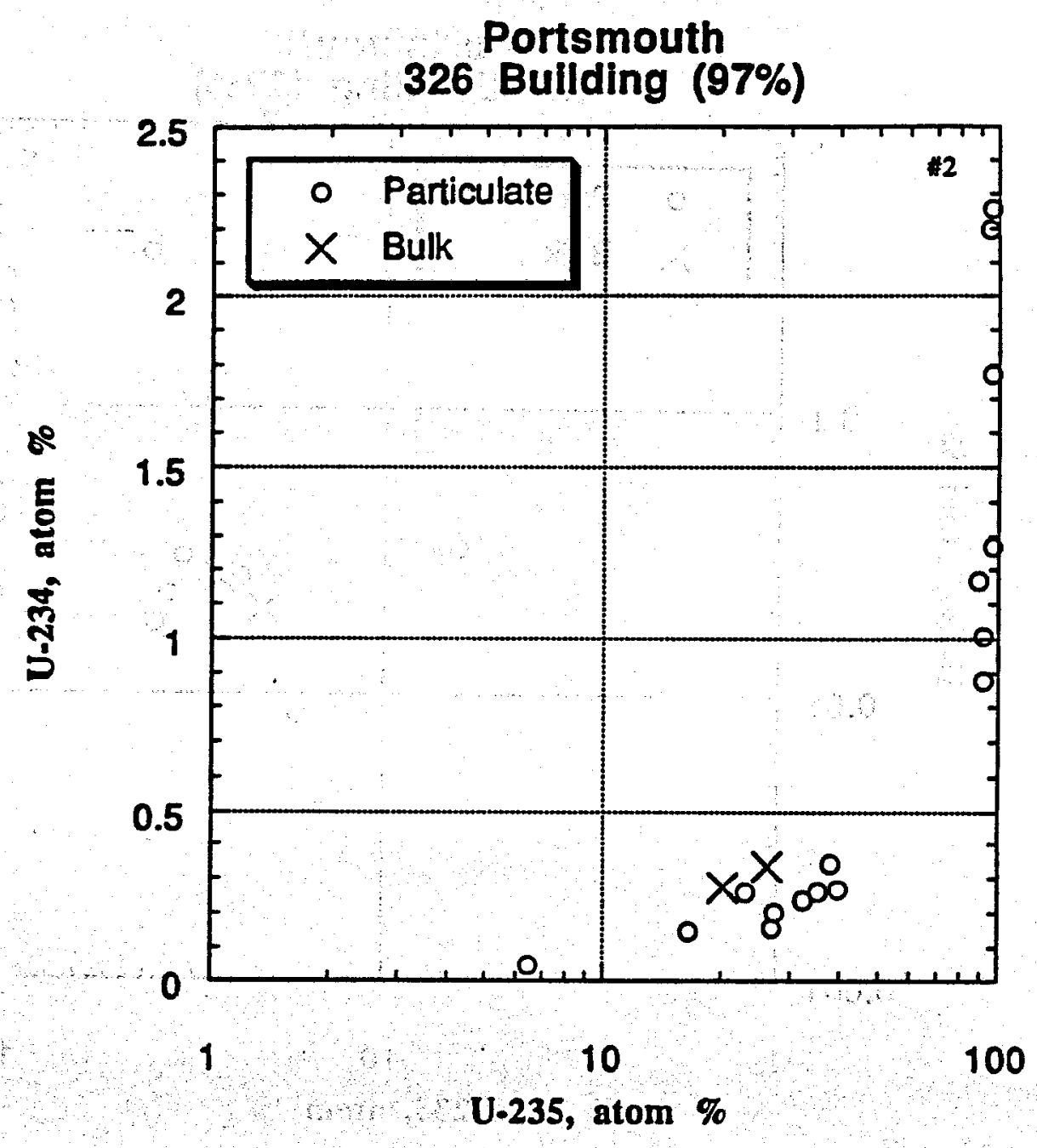




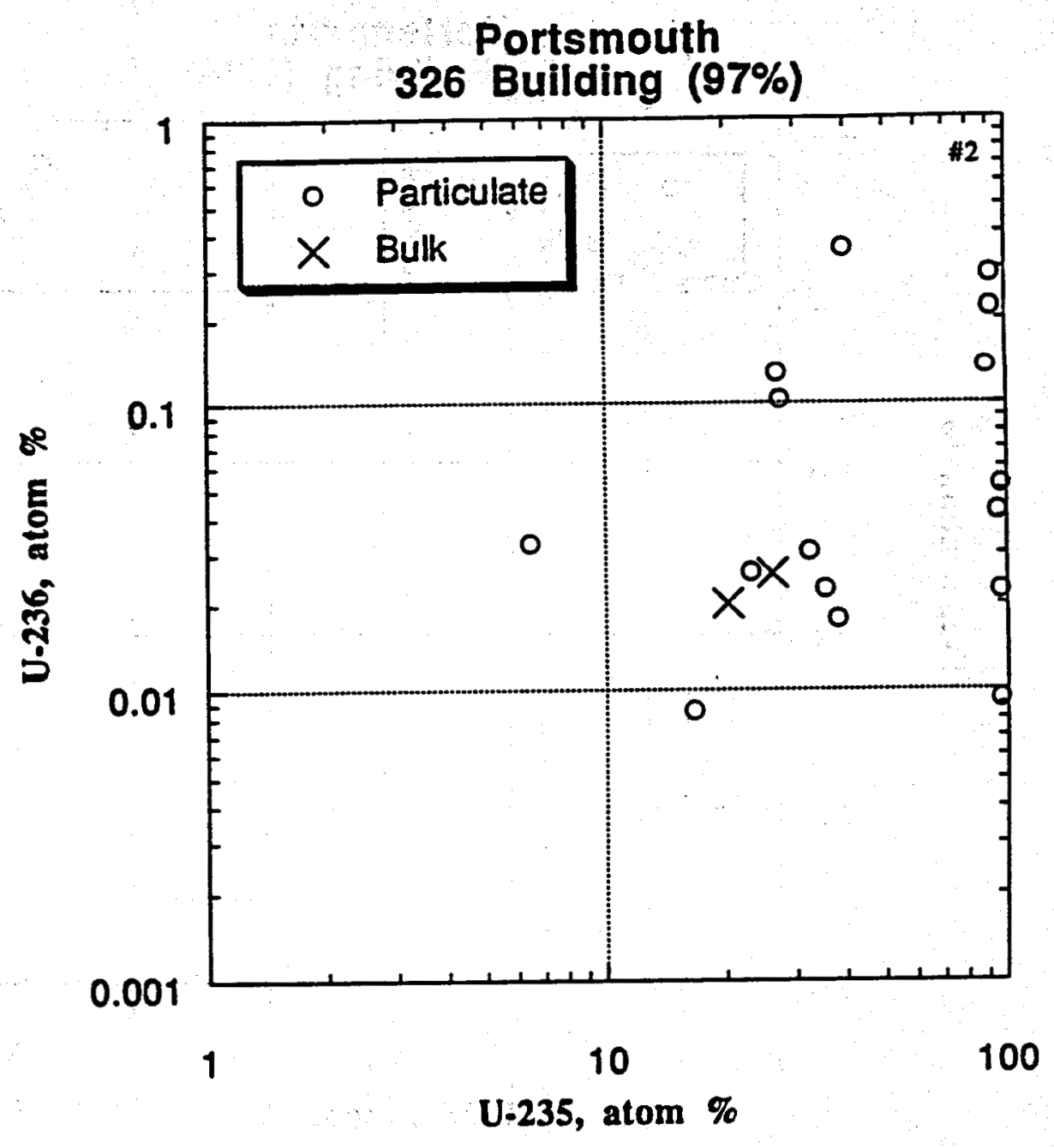




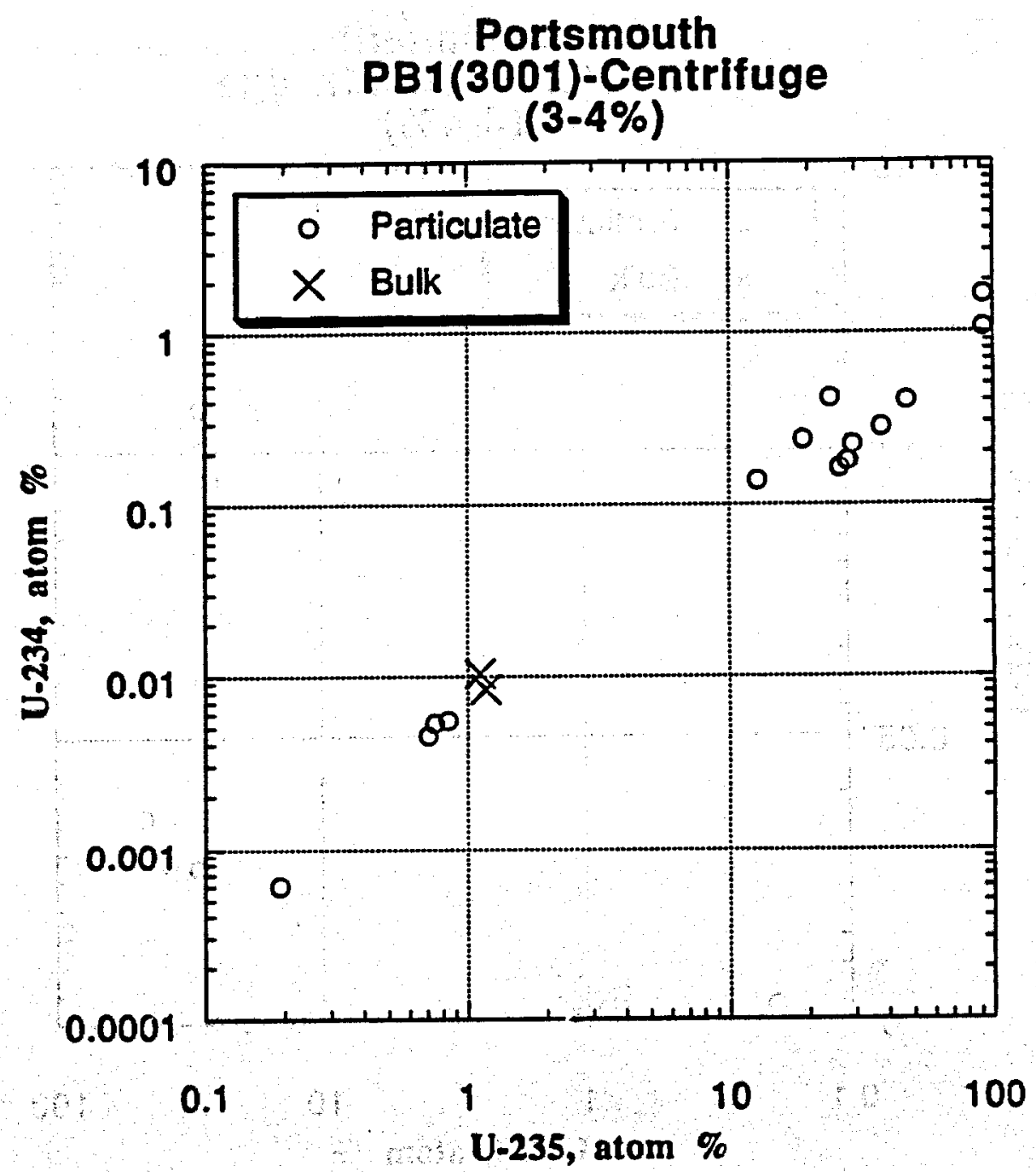




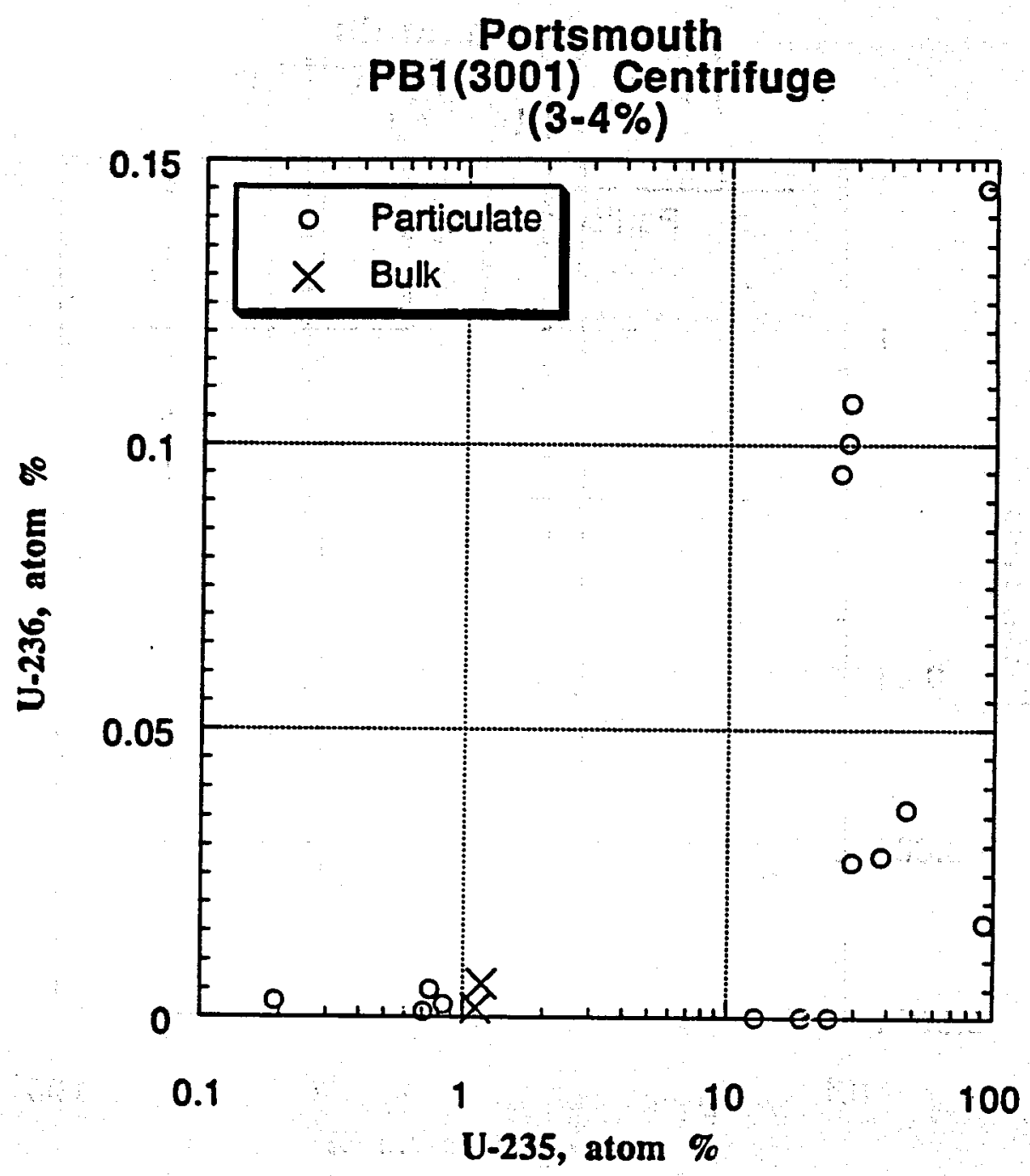


Appendix 4

COMPARISON OF BULK AND PARTICULATE DATA FROM PINE NEEDLE SAMPLES TAKEN DURWNG THE PORTSMOUTH FIEID TRIAL 



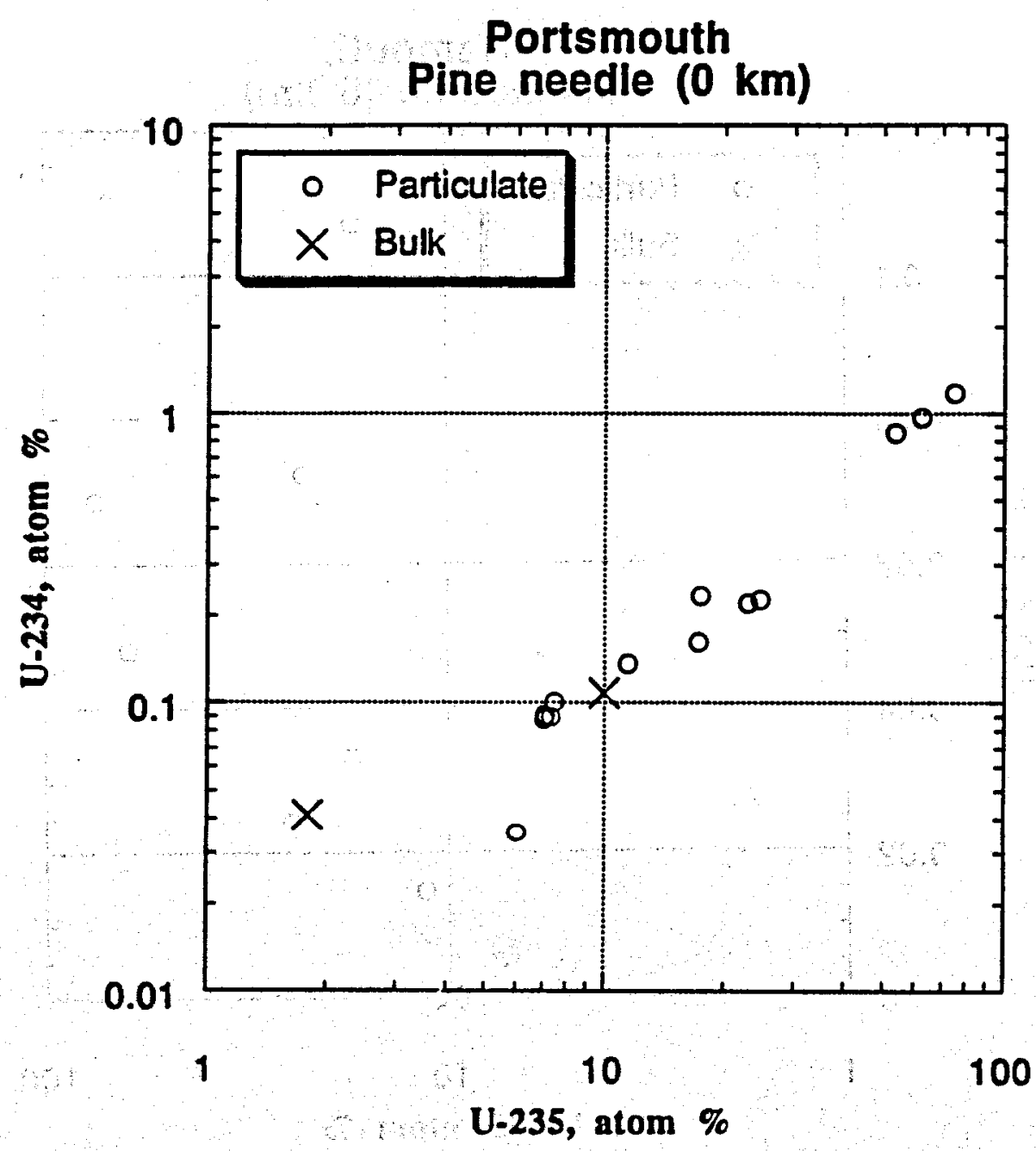




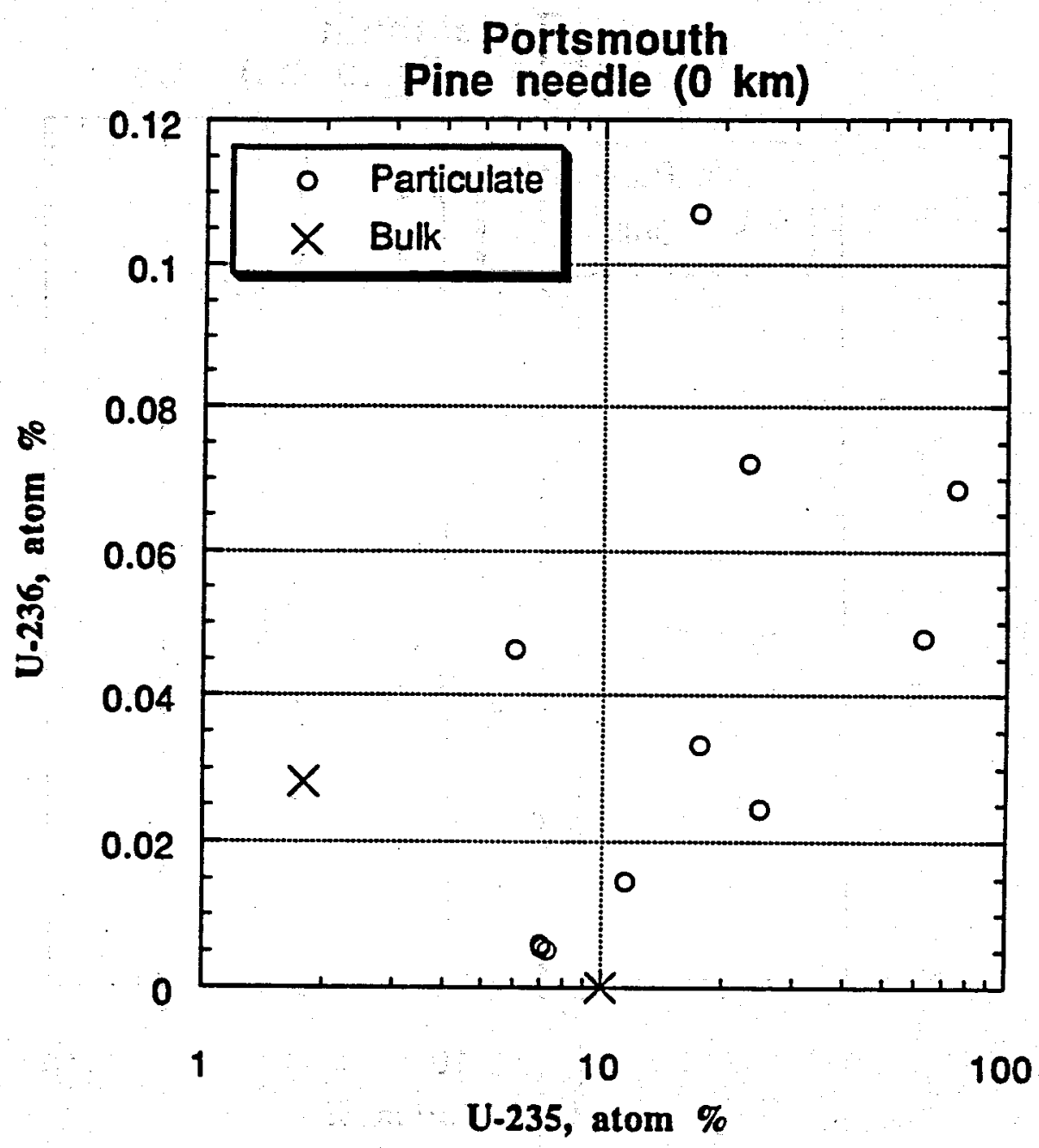




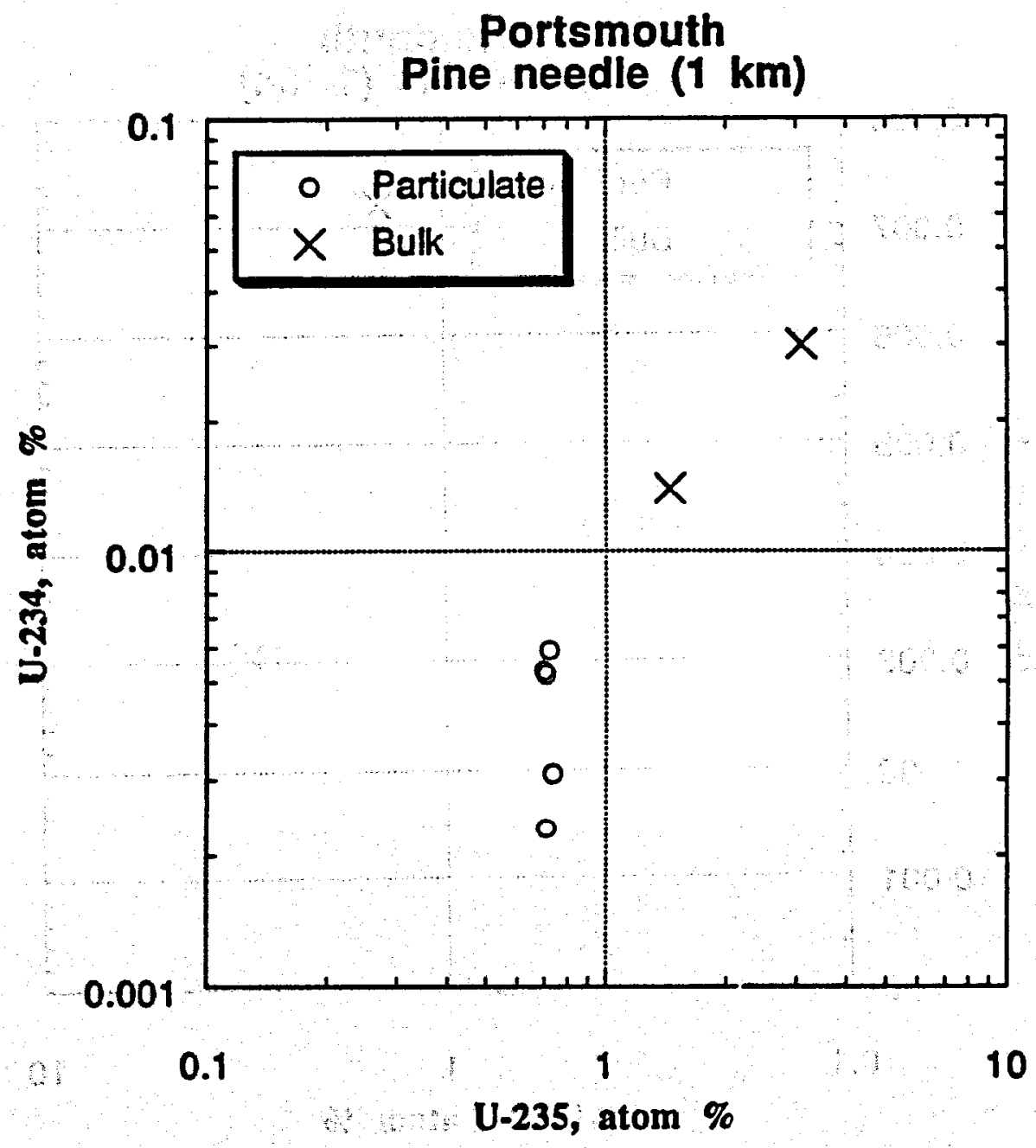




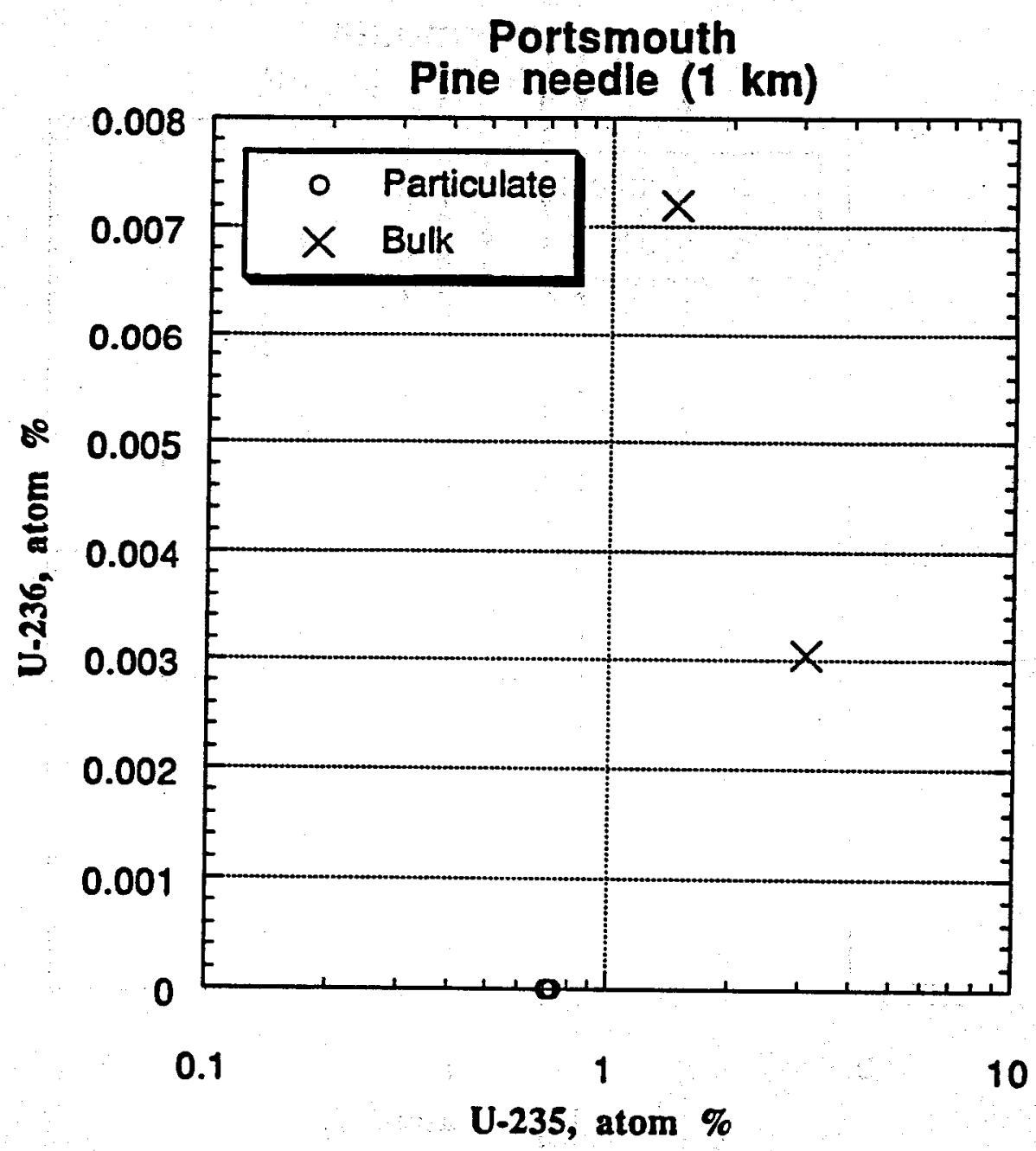




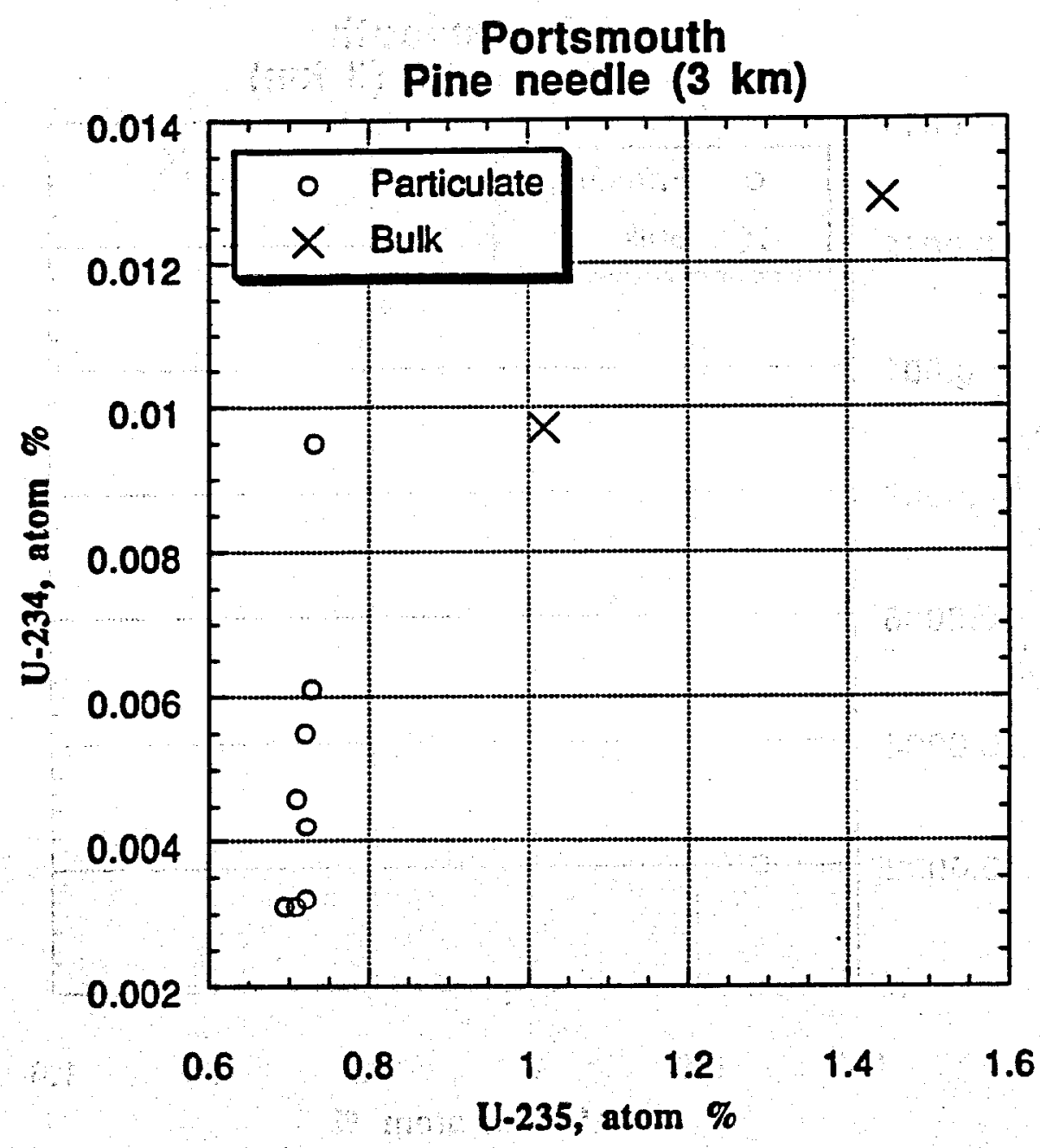




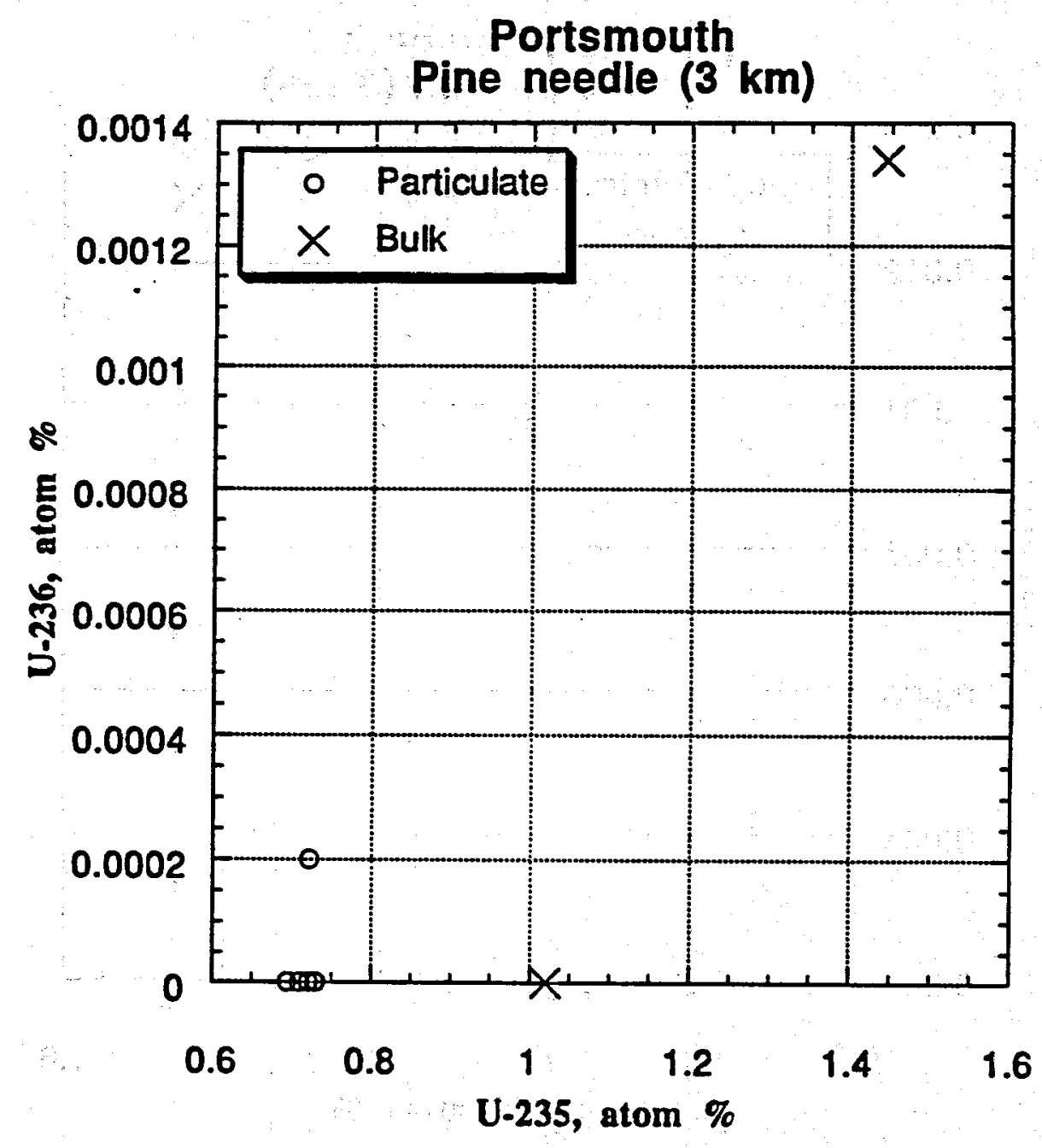




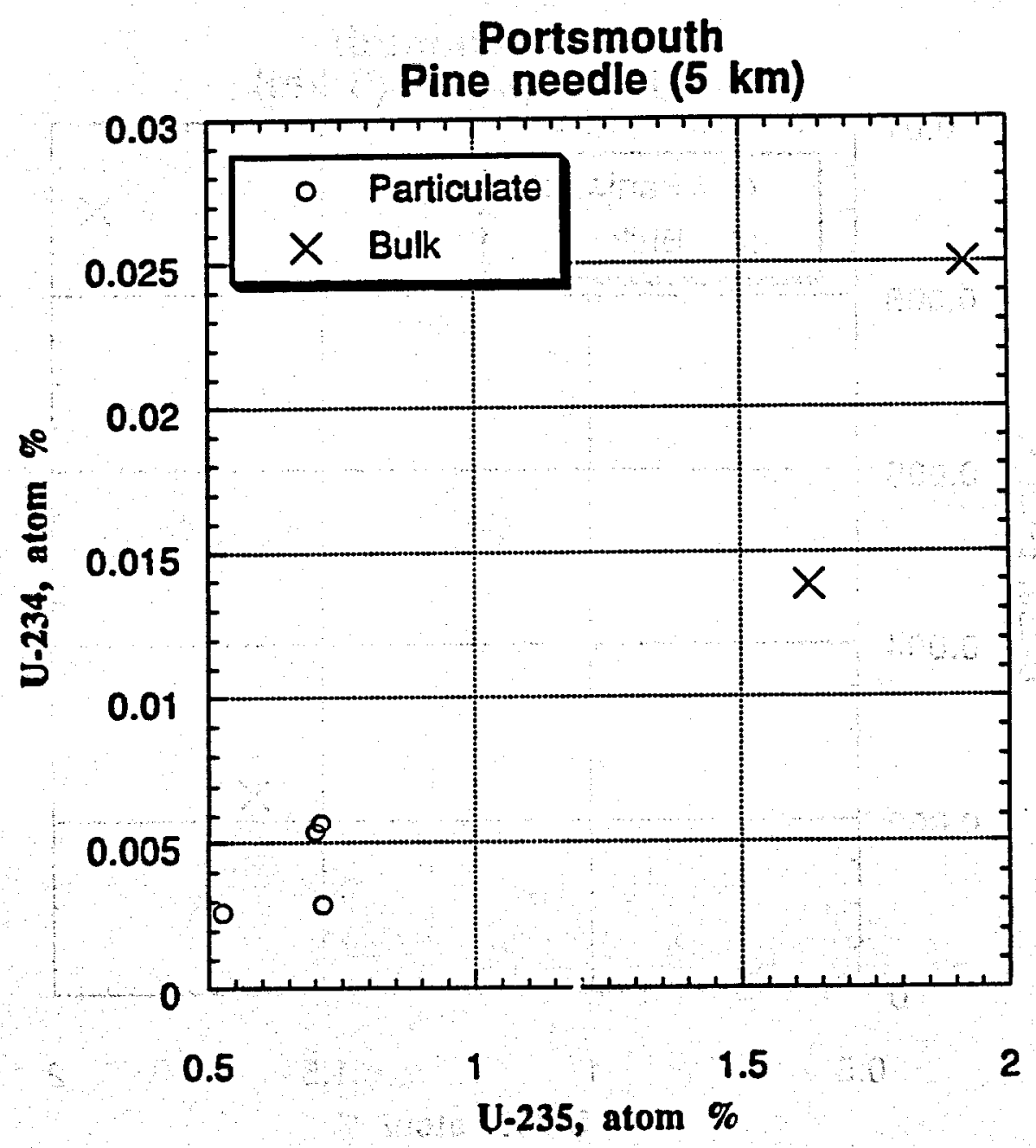

1 


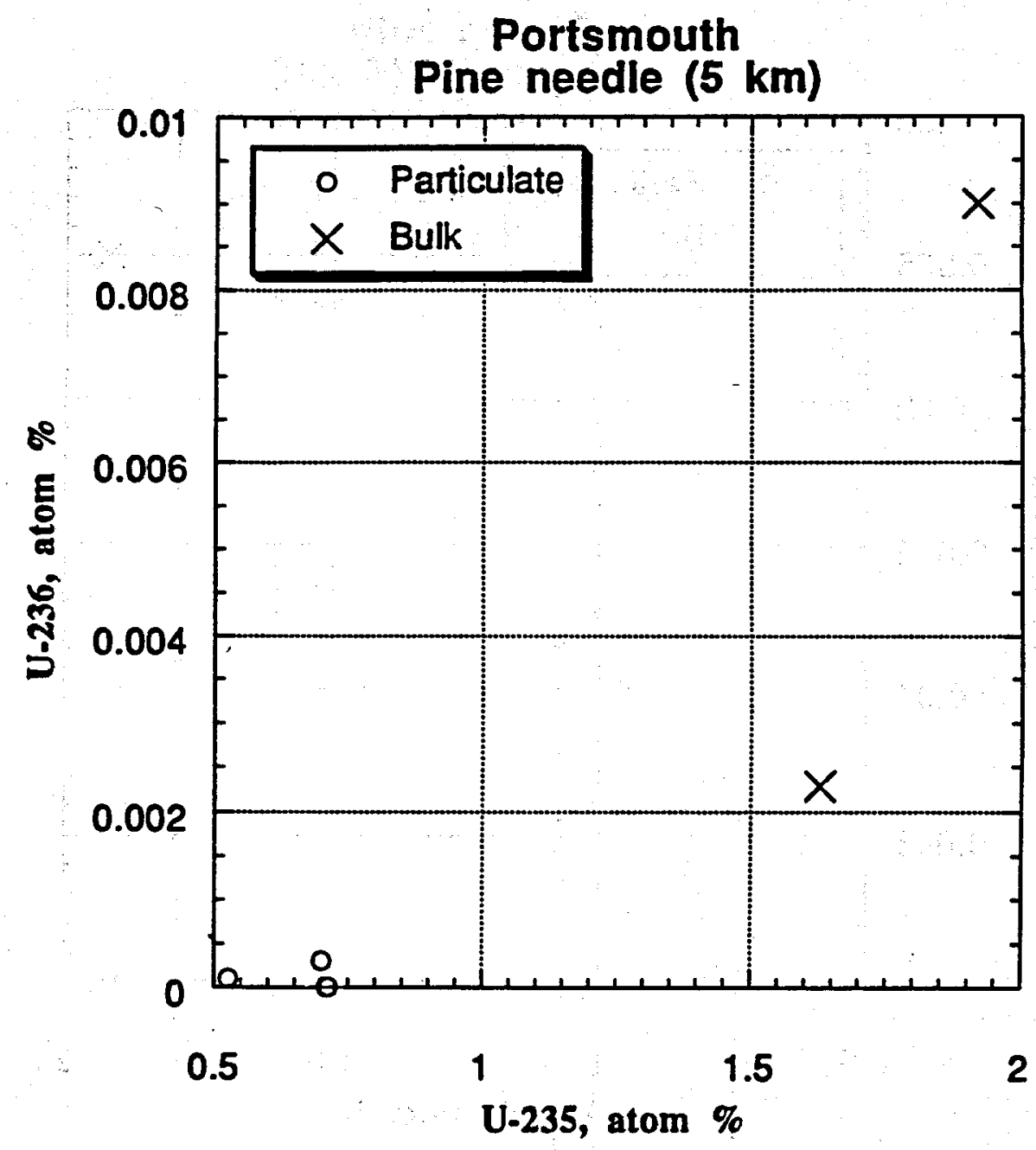


Appendix 5

COMPARISON OF BULK AND PARTICULATE DATA FROM SWIPE SAMPLES TAKEN DURING THE PADUCAH FIEID TRIAL 



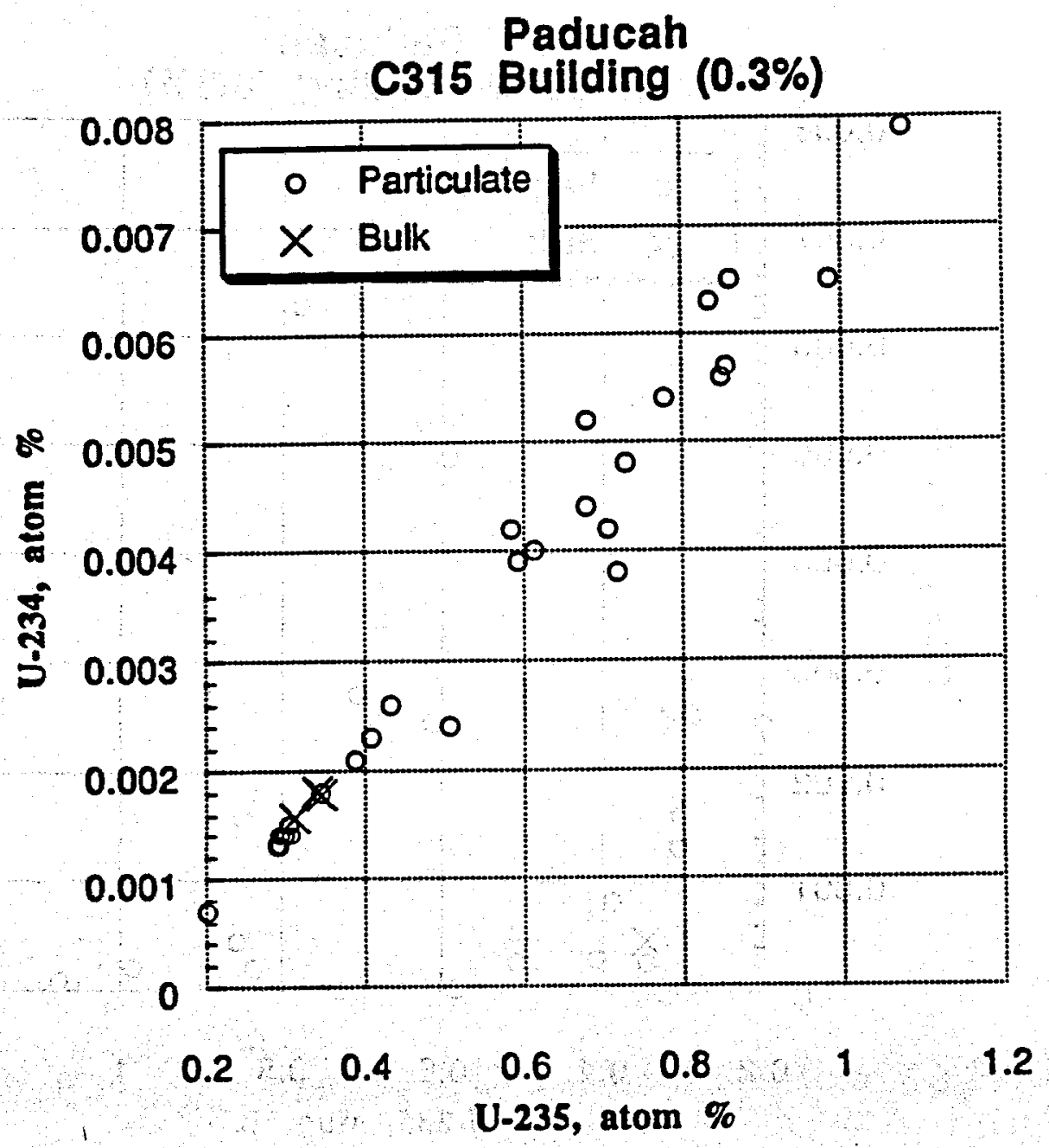




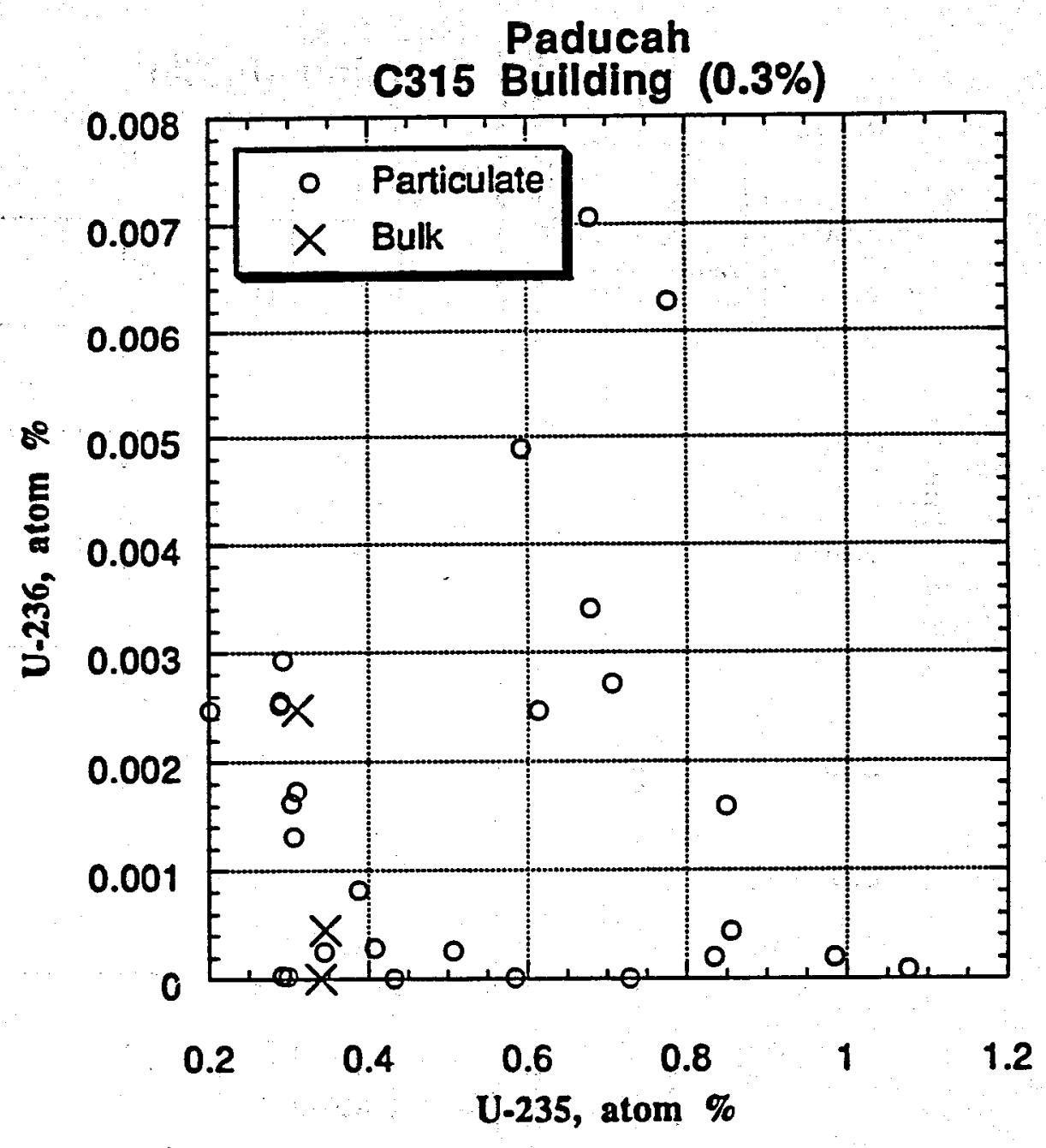




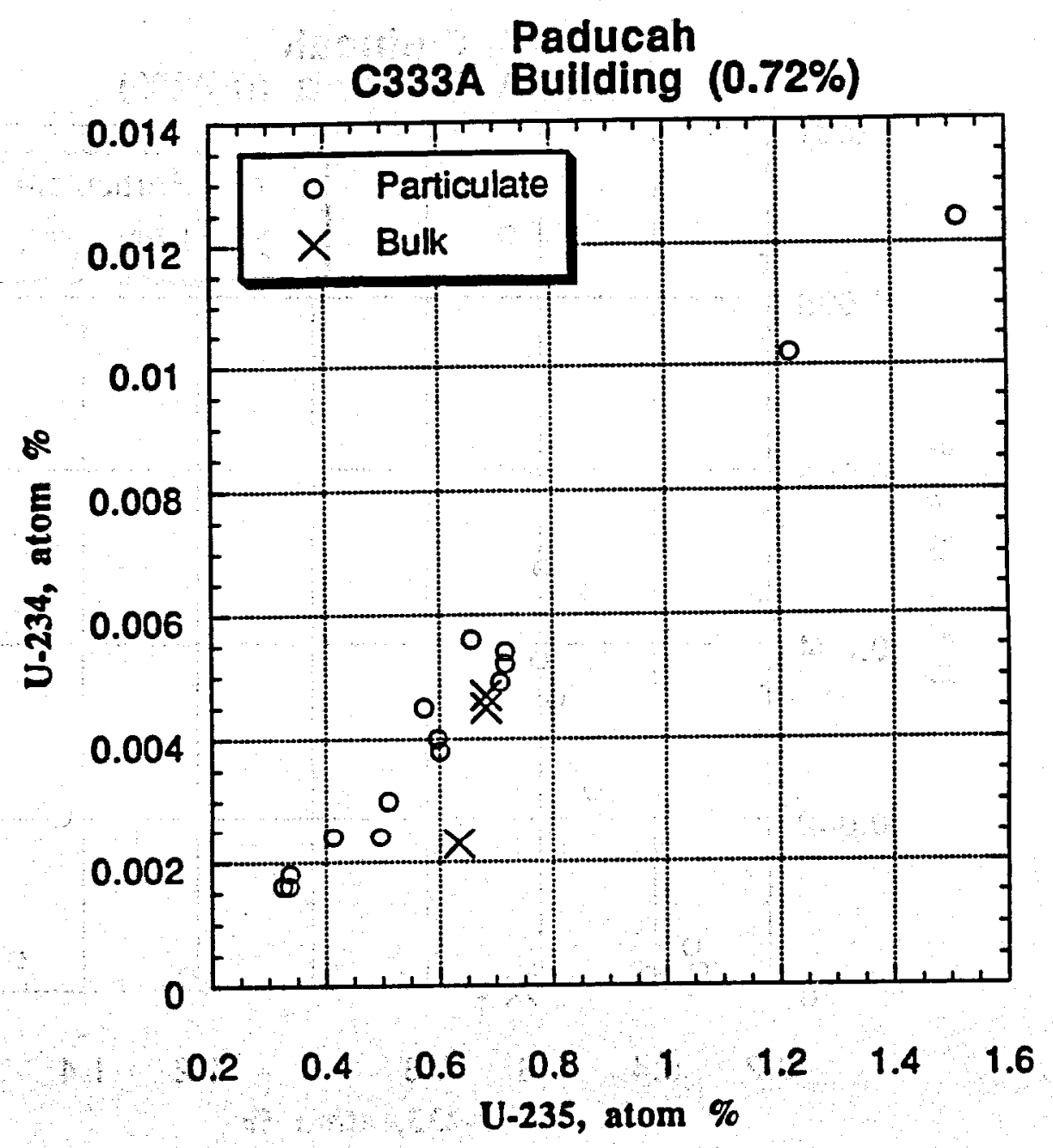




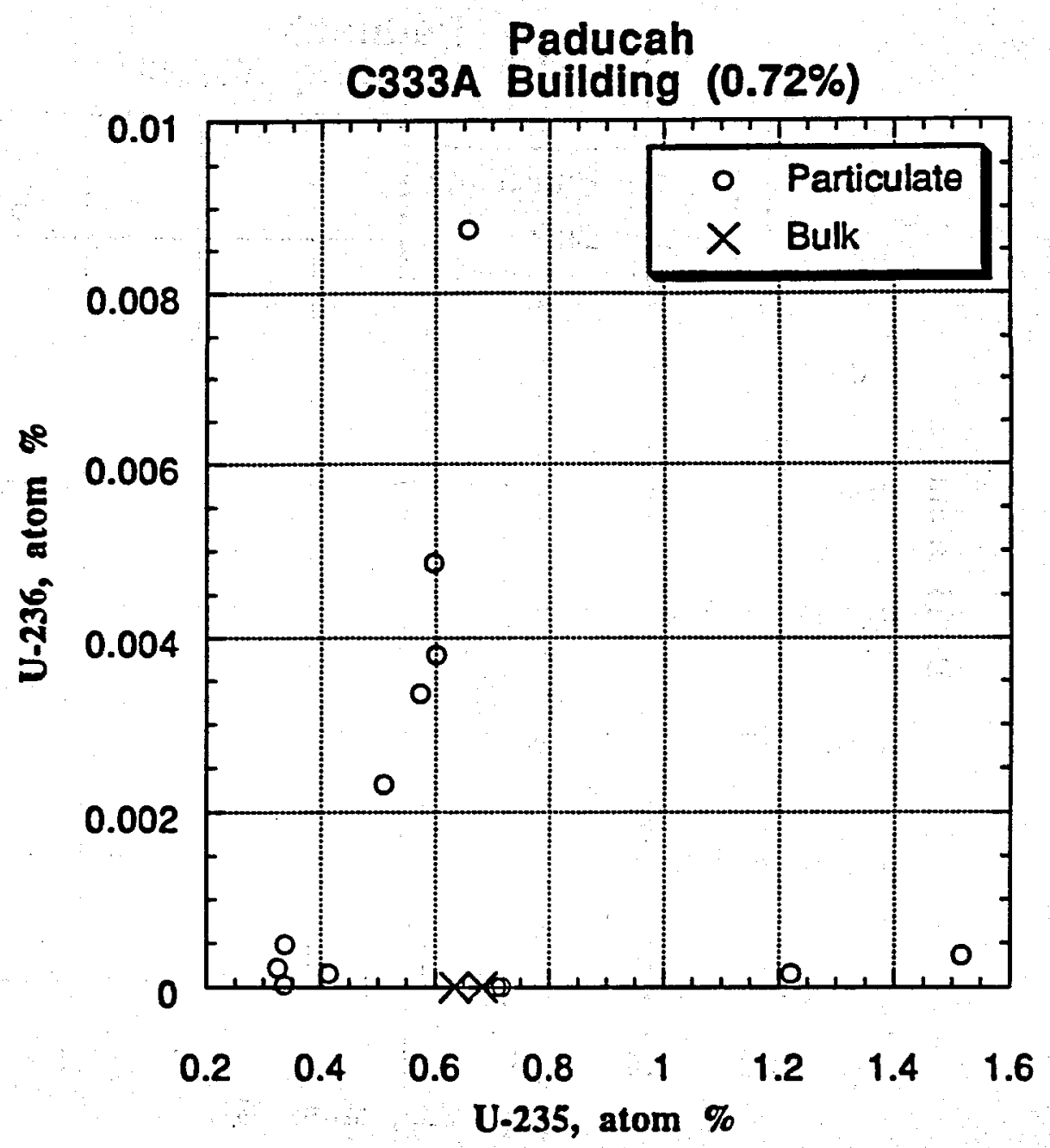




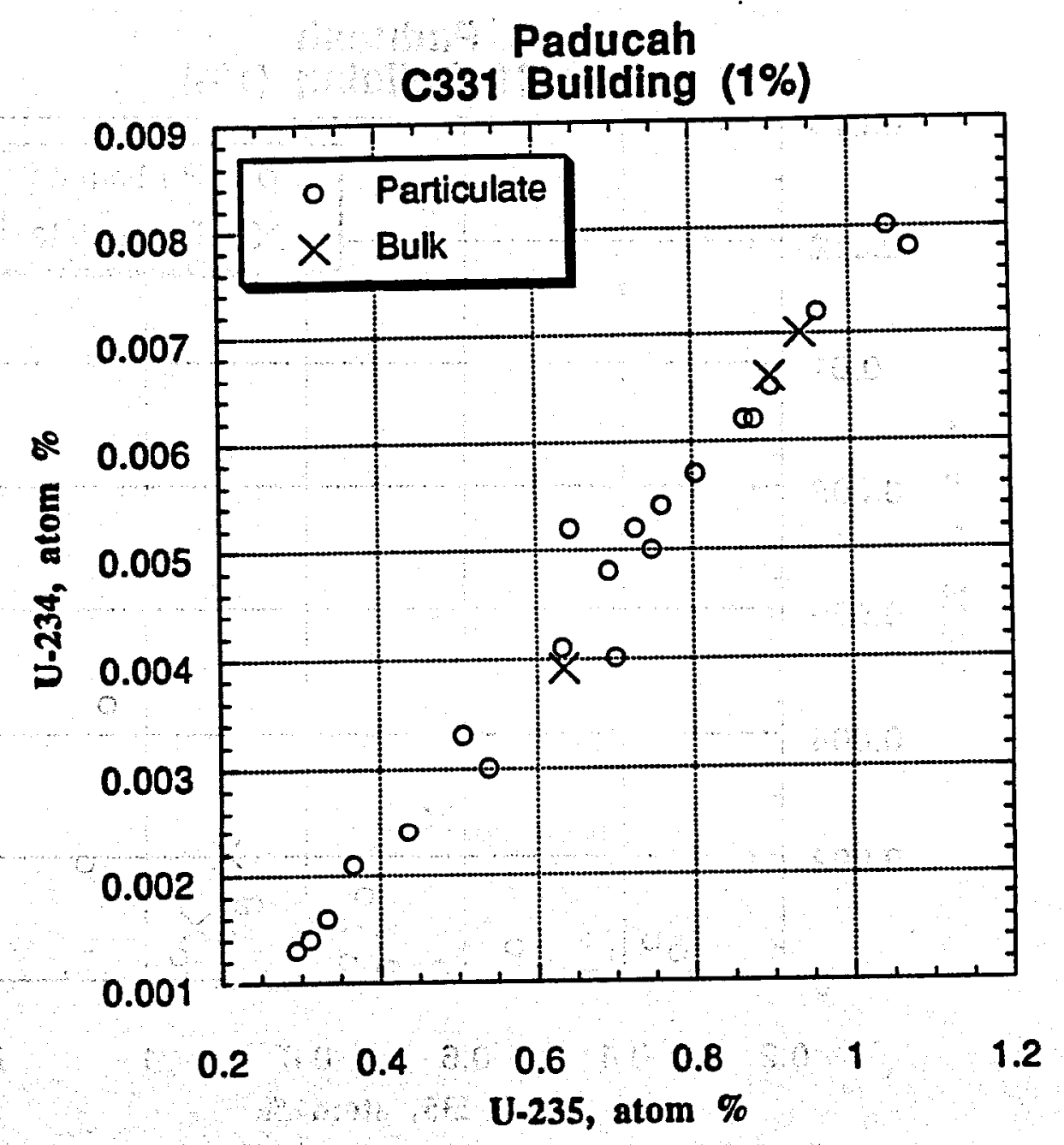




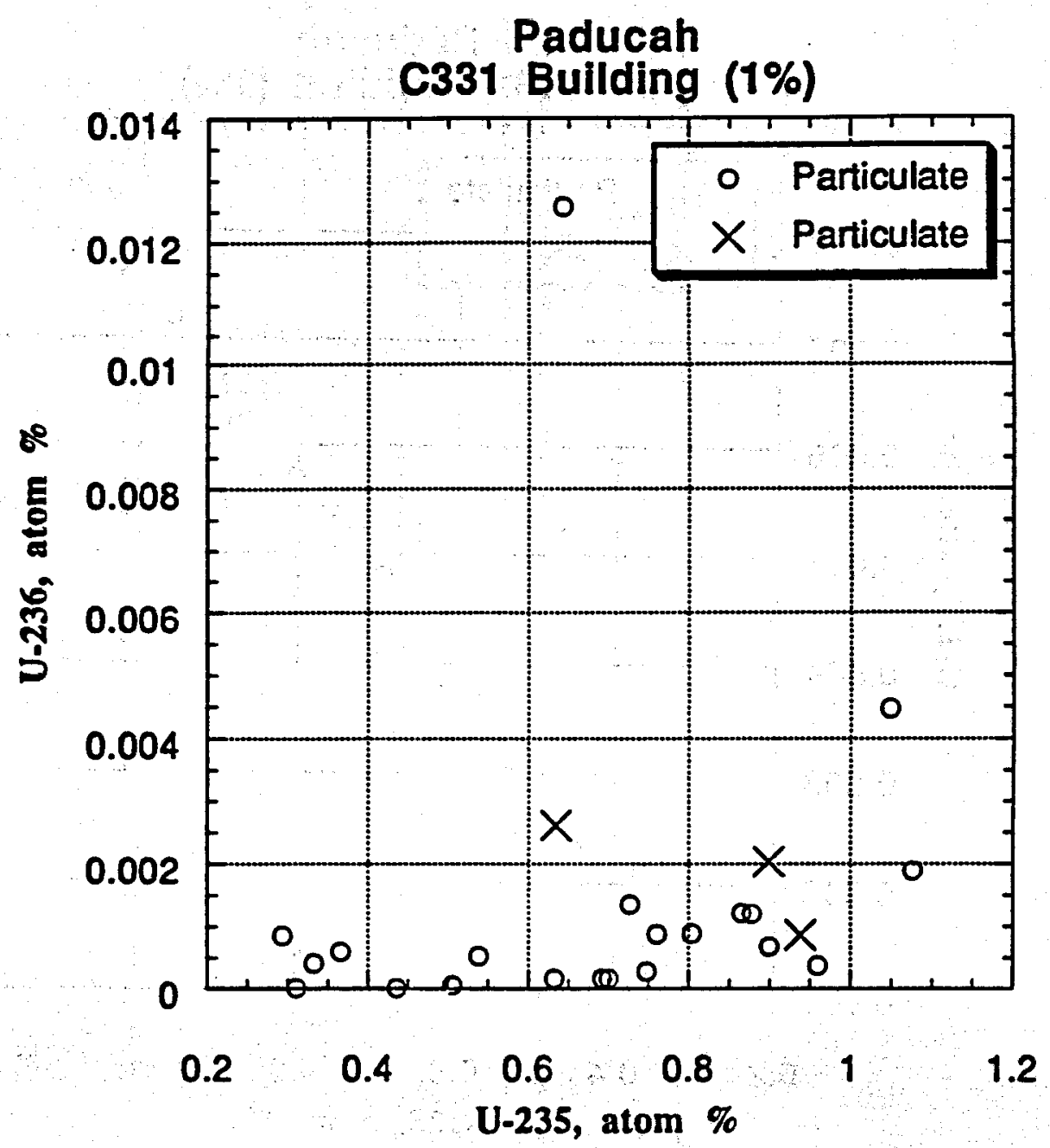


Paducah

C310 Bullding (1.8-2.1\%)

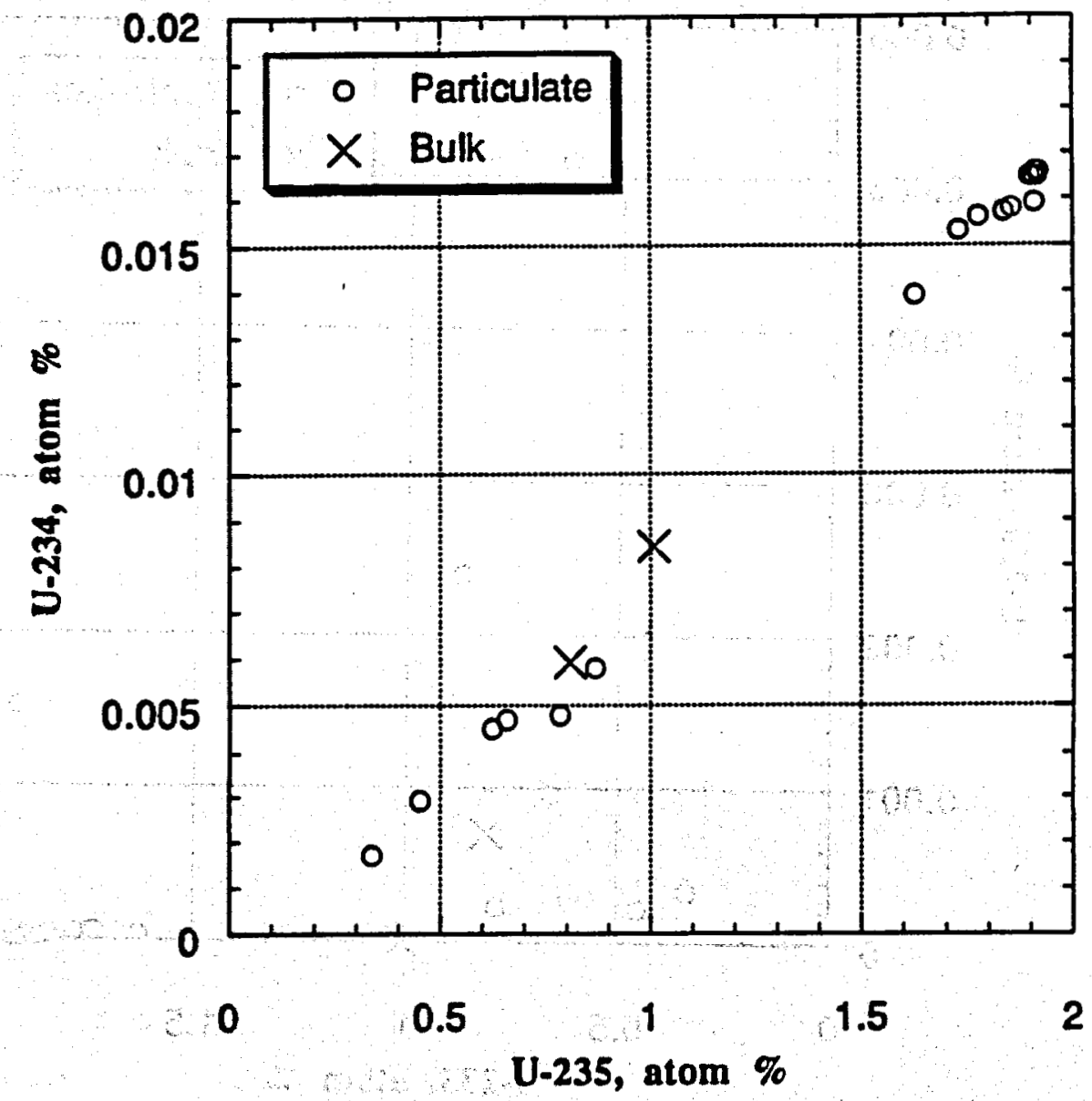




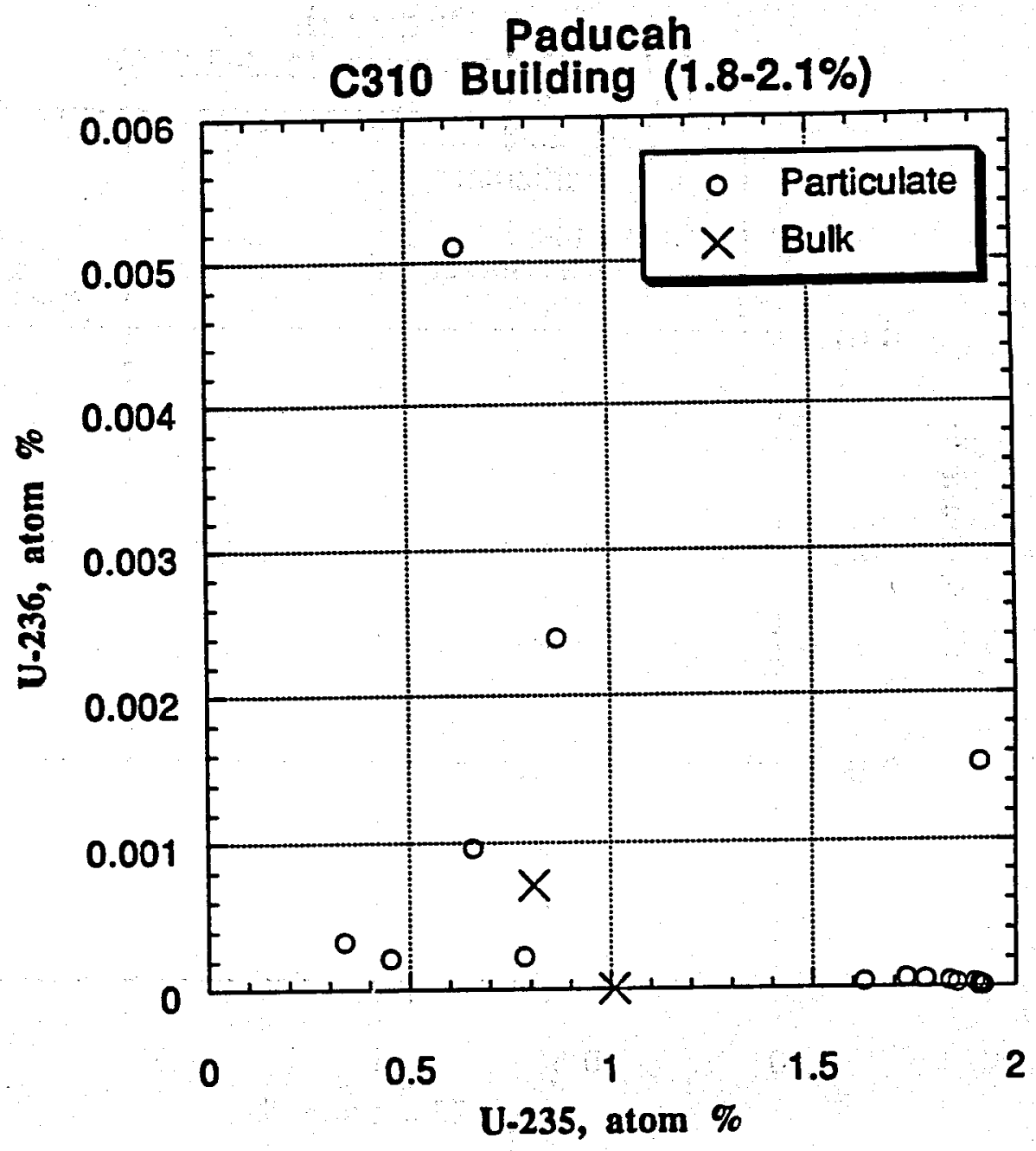




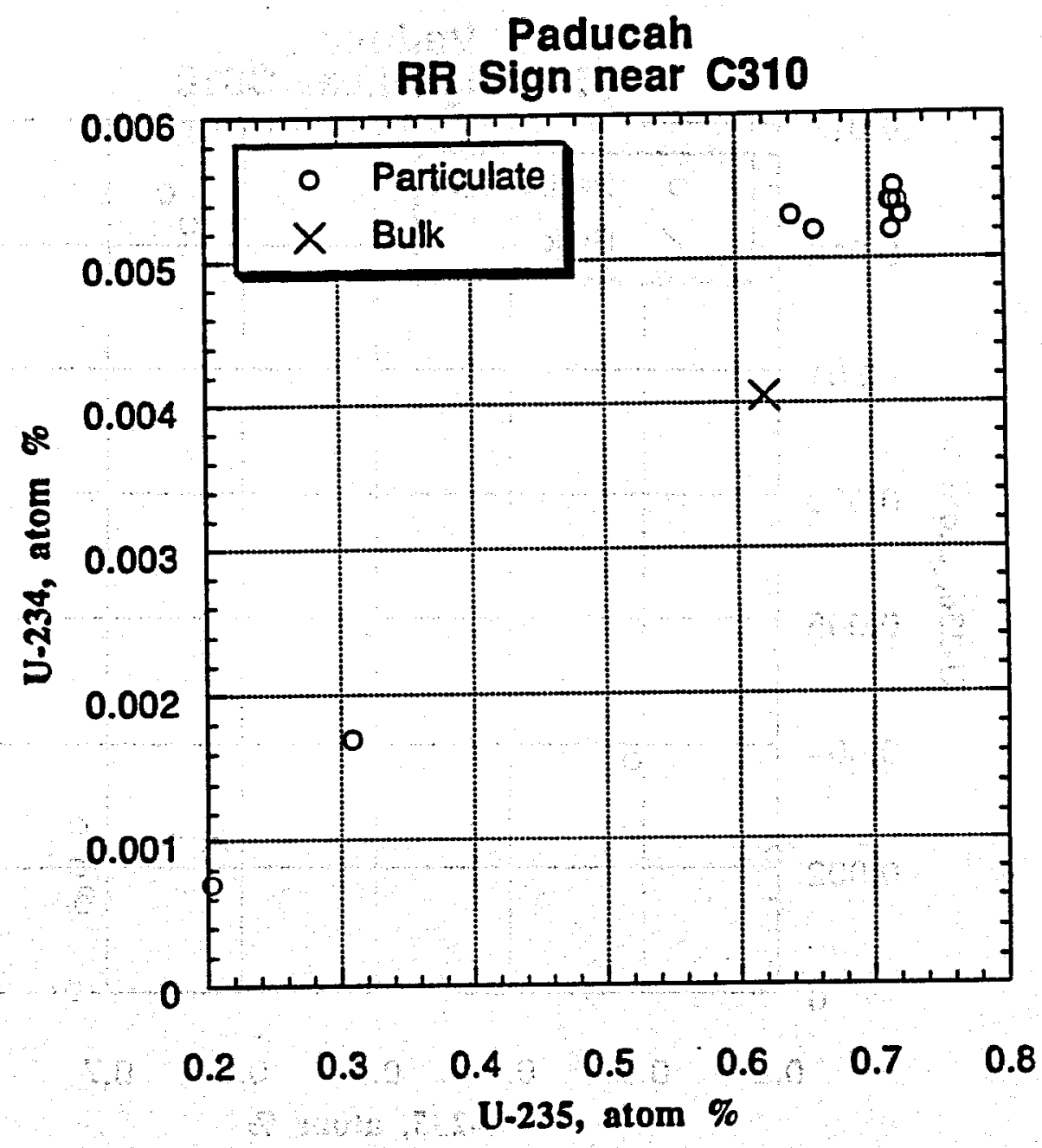




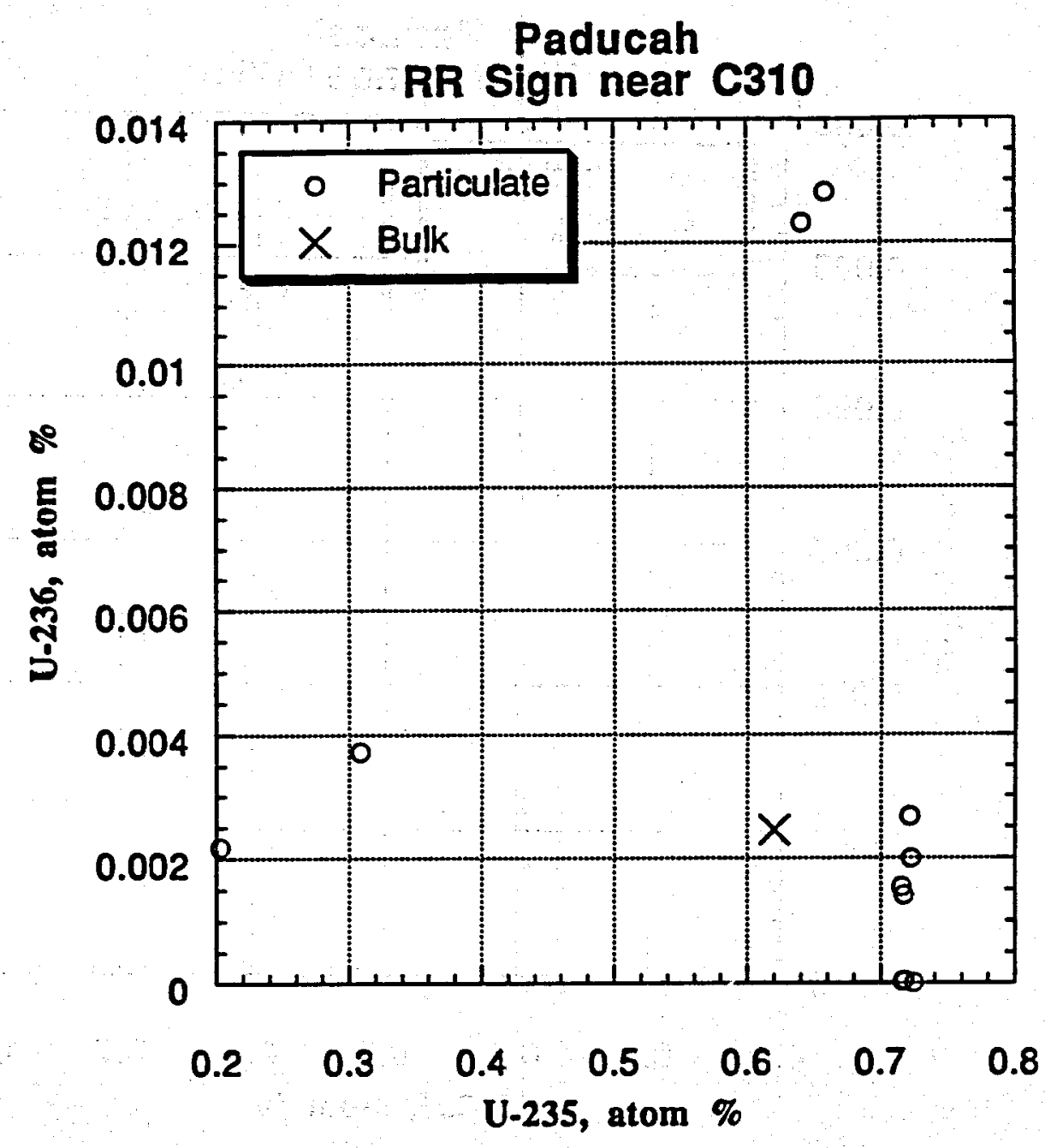


Appendix 6

COMPARISON OF BULK AND PARTICULATE DATA FROM PINE NEEDLE SAMPLES TAKEN DURING THE PADUCAH FIEID TRIAL 
5 


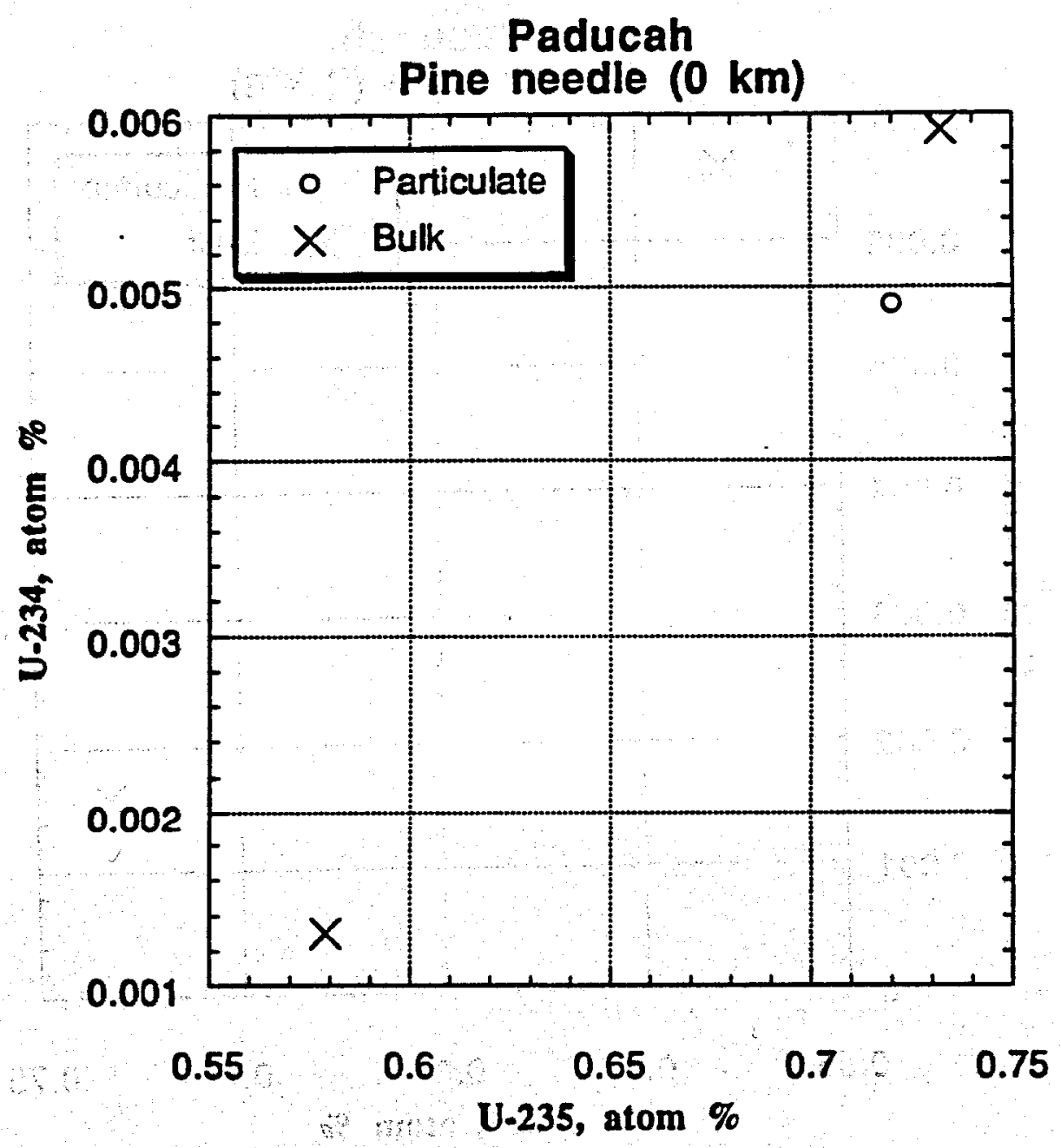




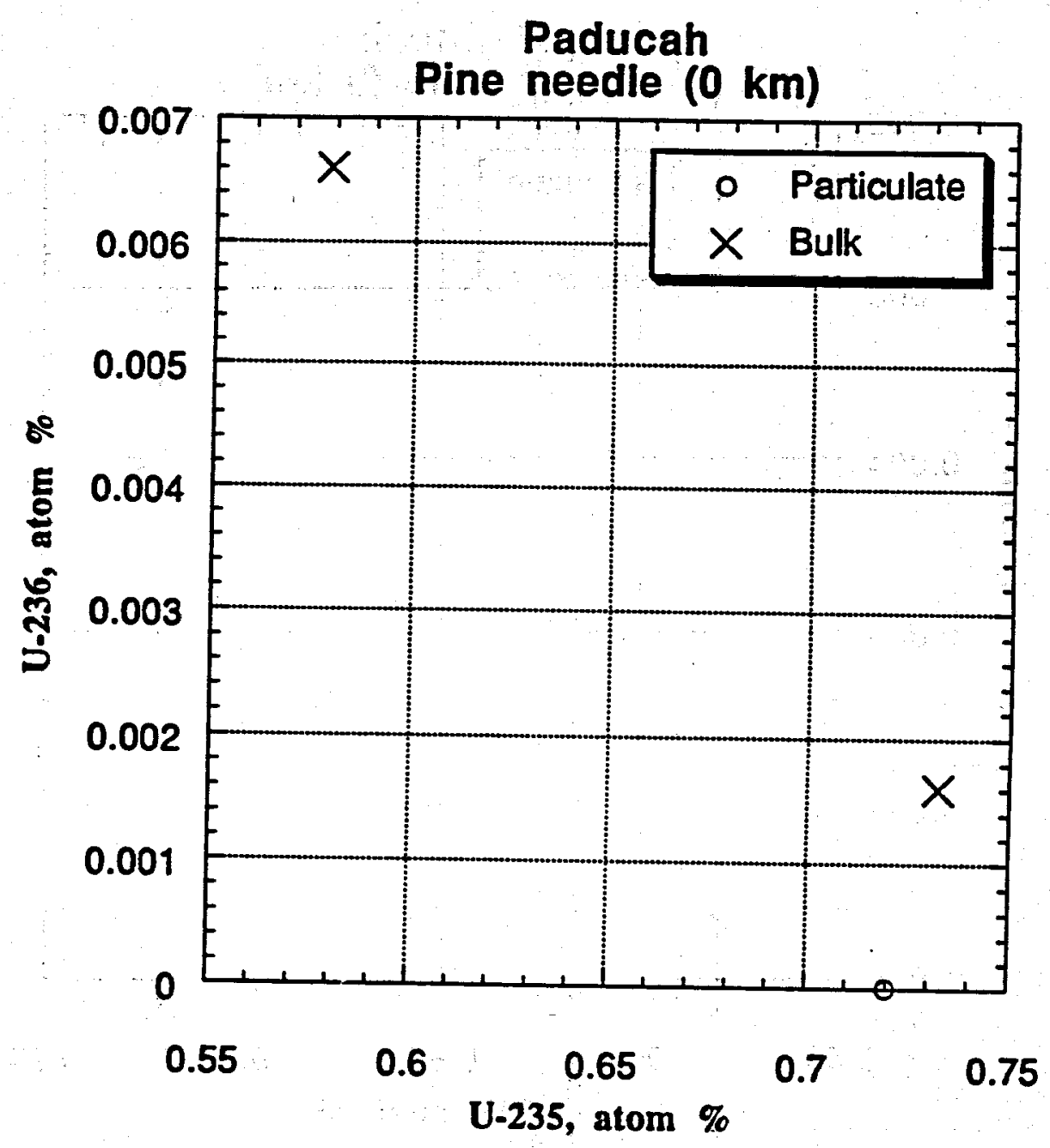




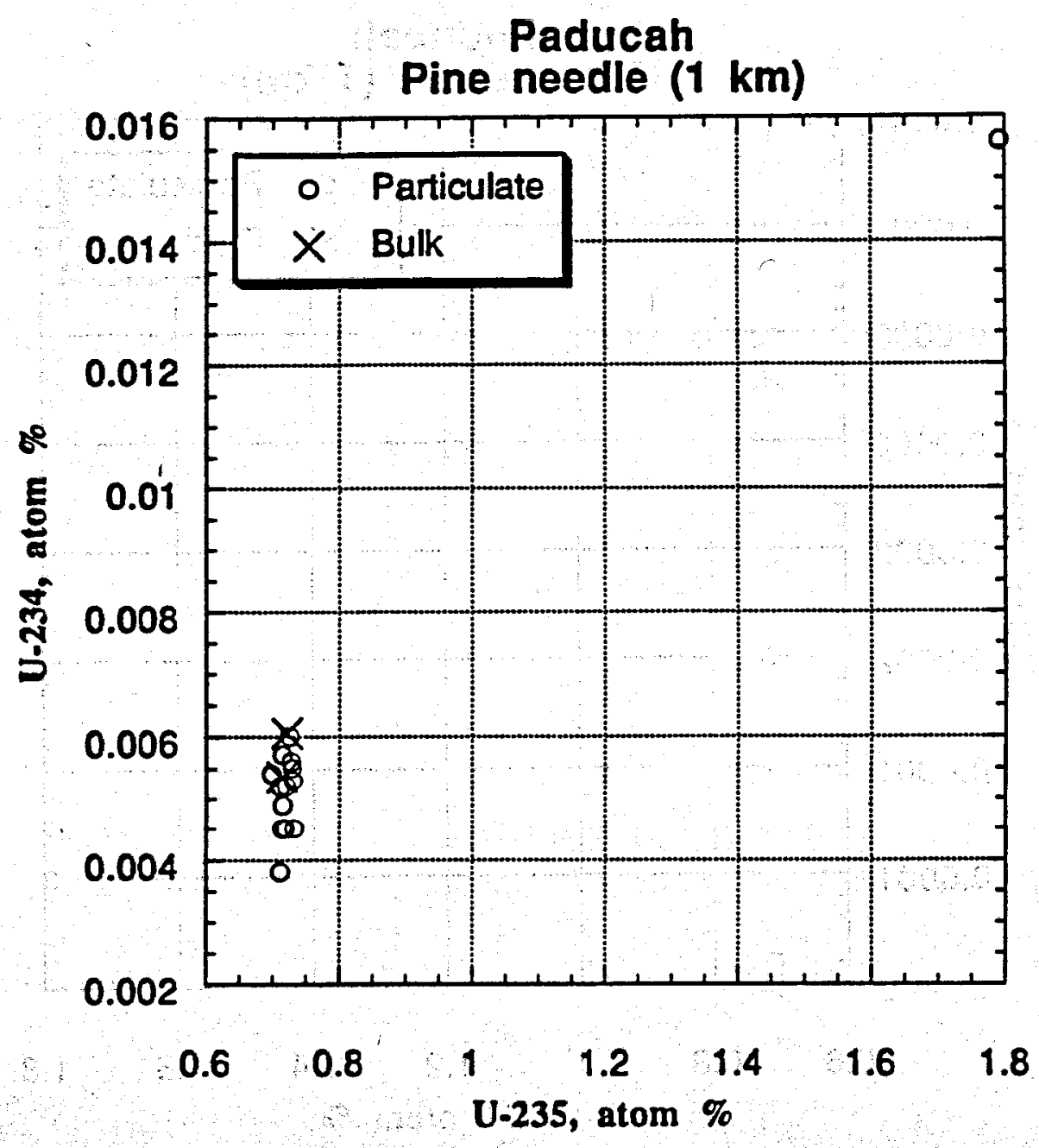




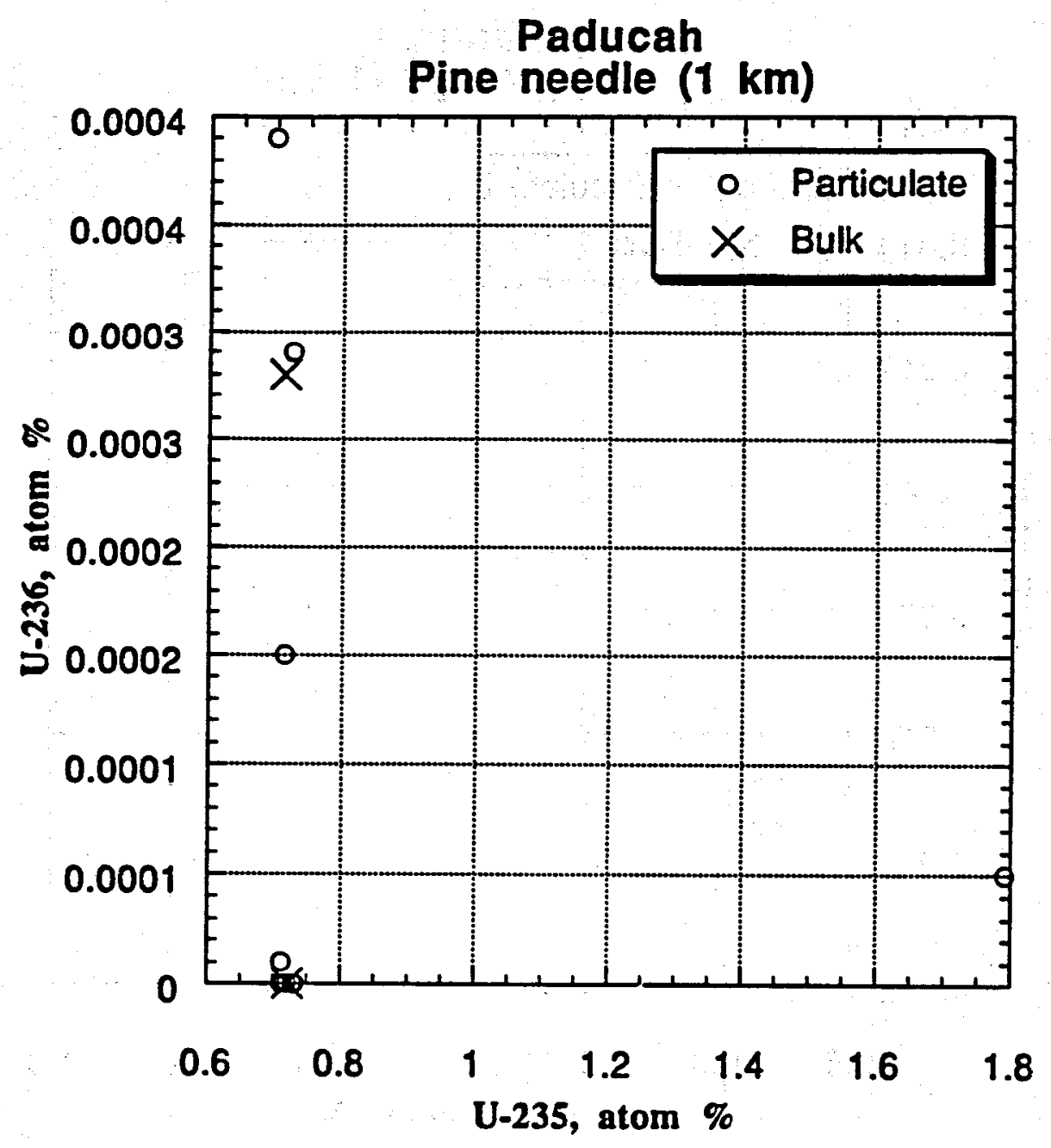




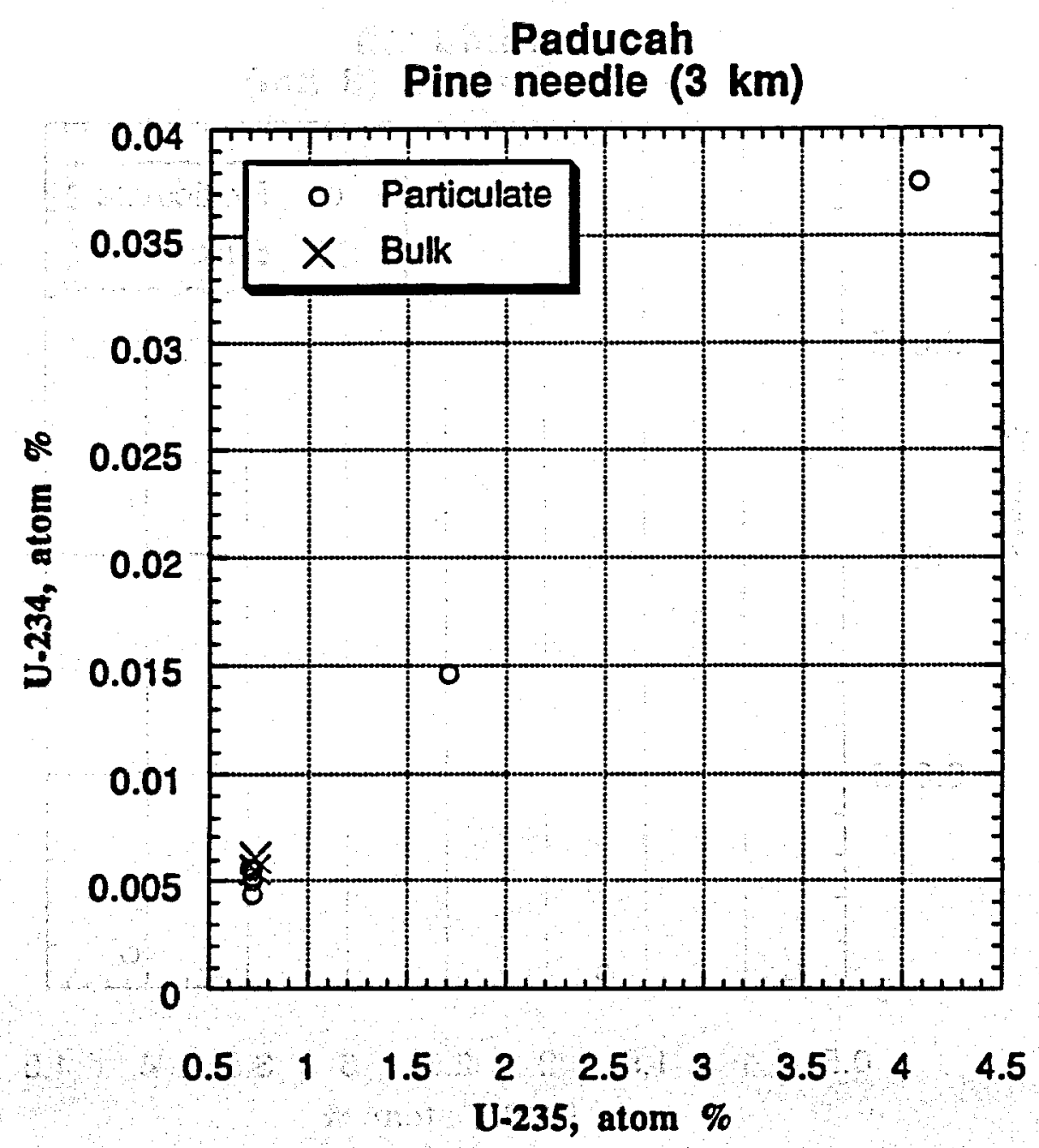




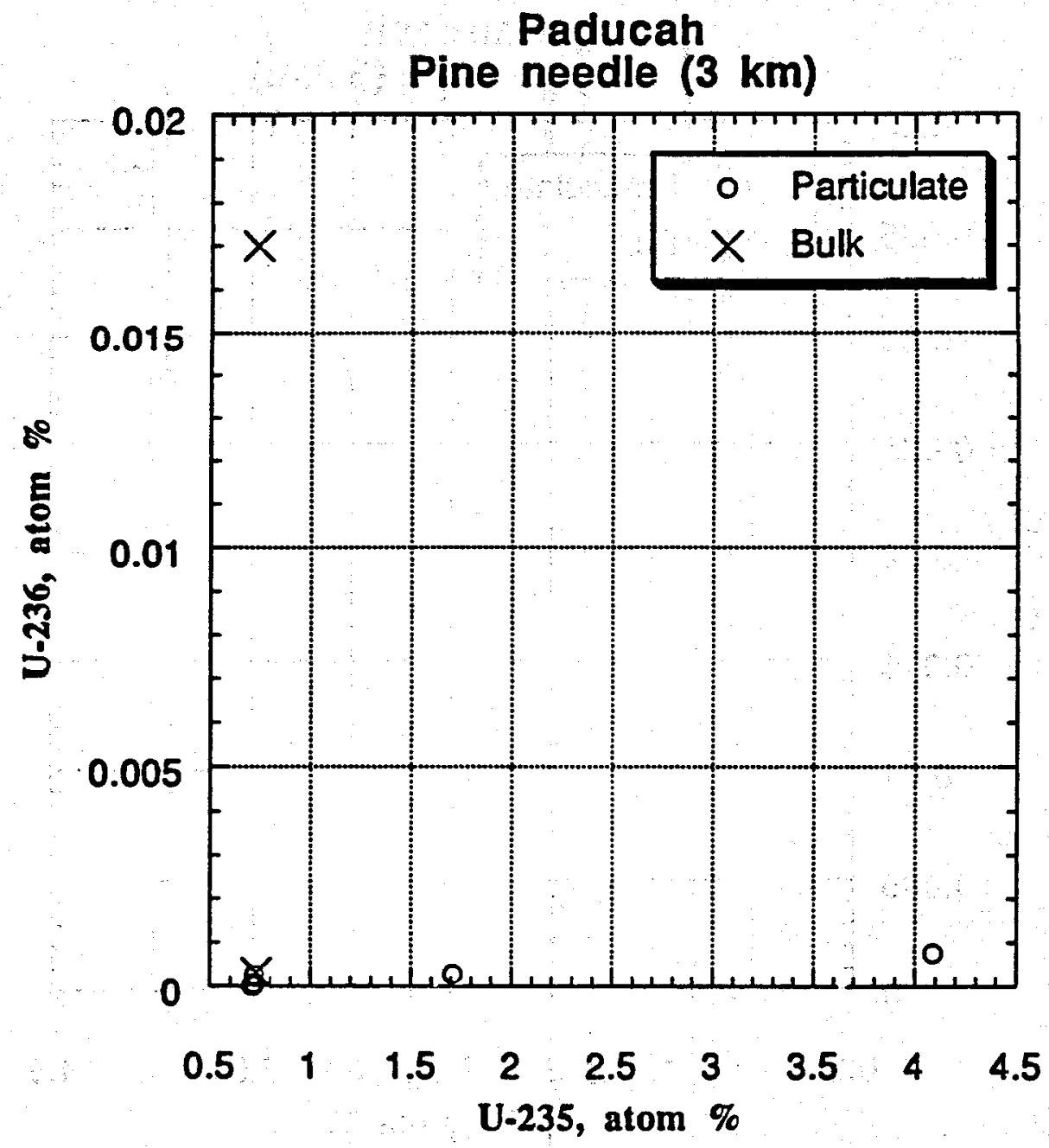




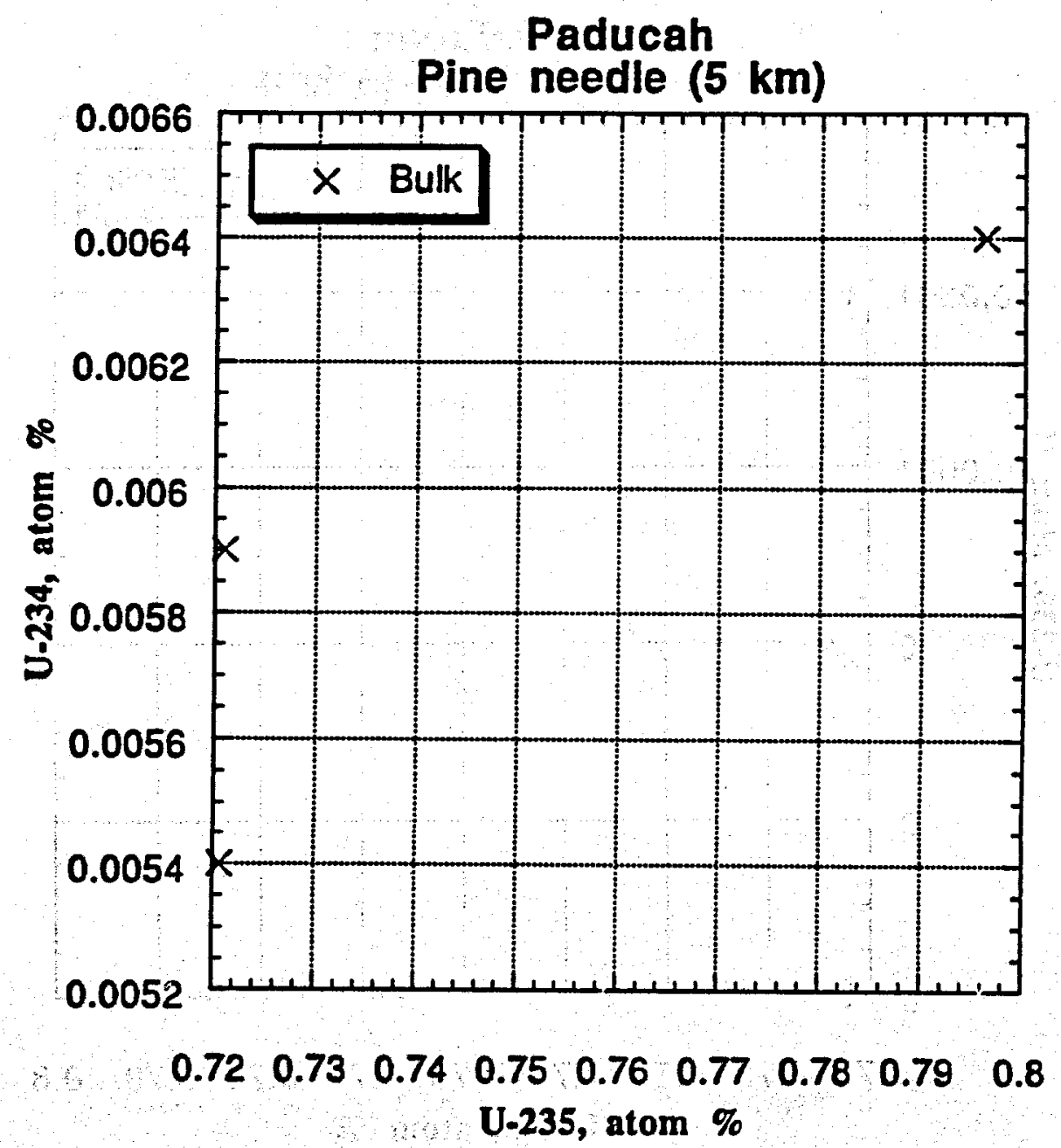




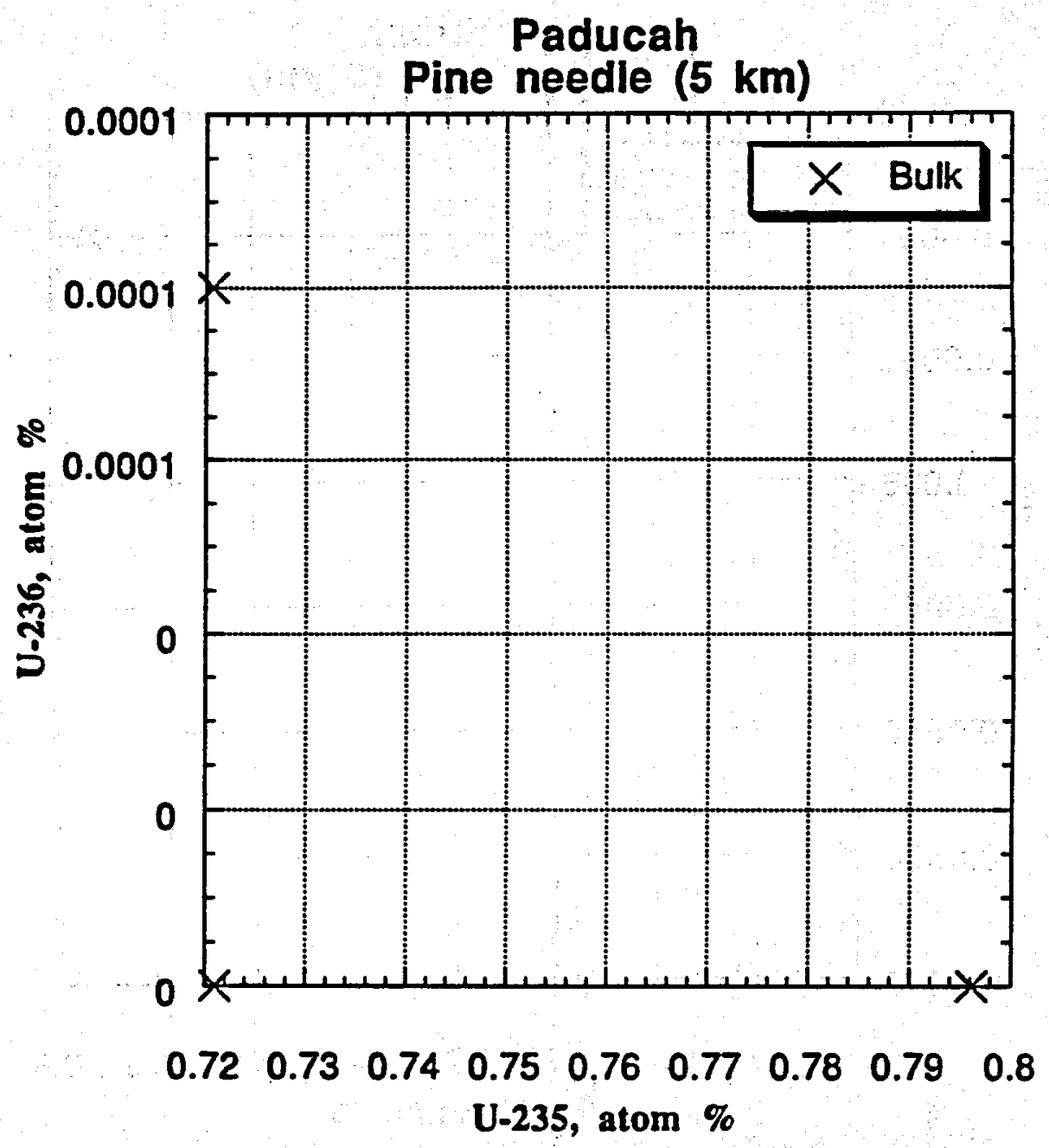




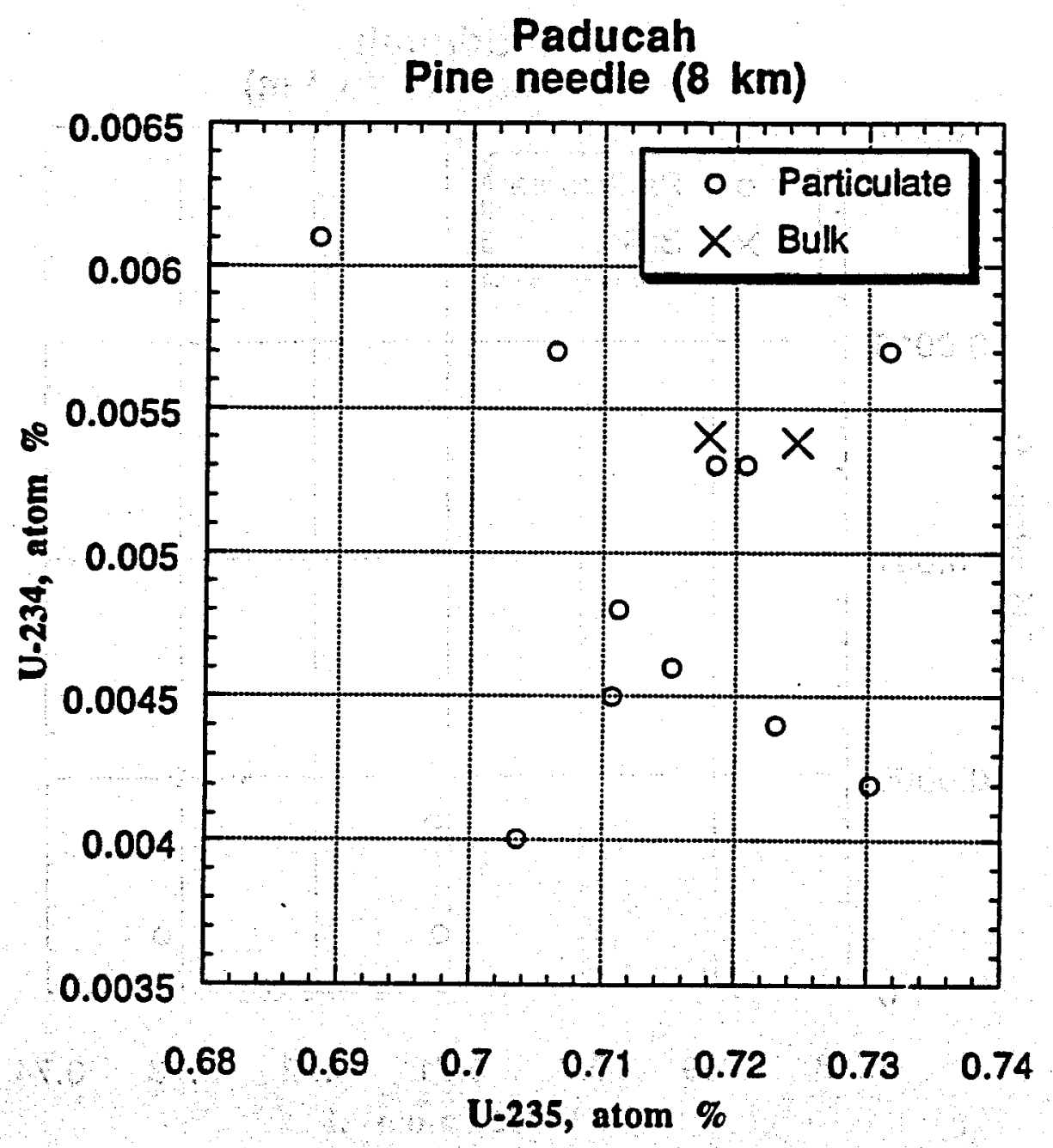




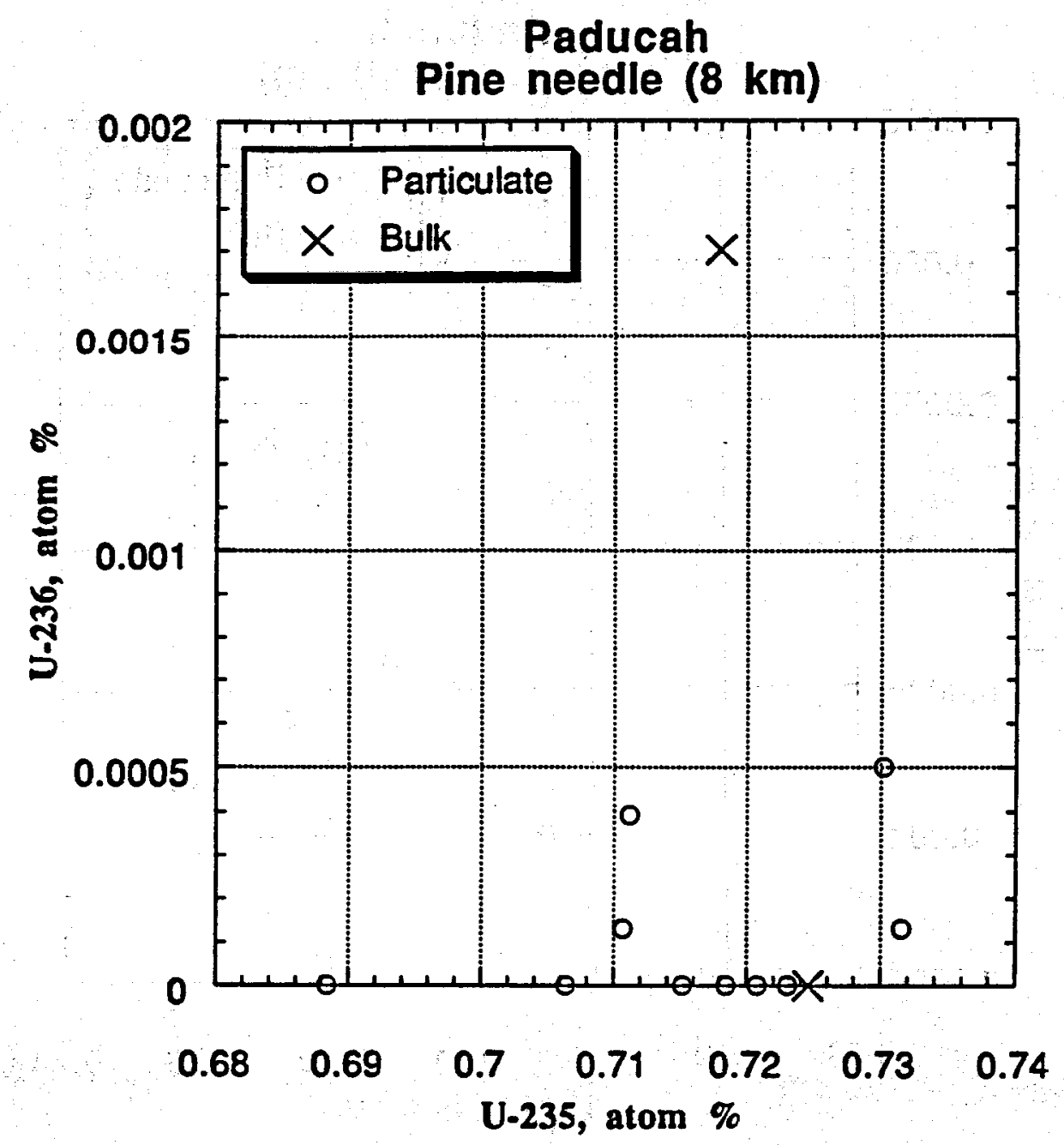




\section{DISTRIBUTION}

1-30. Martin Marietta Energy Systems, Inc.

J. A. Carter (2)

R. S. Eby (3)

M. H. Ehinger (2)

D. M. Hembree (2)

H. H. Ross (18)

R. E. Upchurch

Laboratory Records

NSPO Central Files - F3-3

31-41. U.S. Department of Energy, Oak Ridge Operations

E. W. Gillespie, Portsmouth Site Manager (5)

J. C. Hall, Asst. Manager of Research and Development

J. C. Hodges, Paducah Site Manager (5)

42. Office of Scientific and Techical Information 